\title{
Flood Study of the Suncook River in Epsom, Pembroke, and Allenstown, New Hampshire, 2009
}

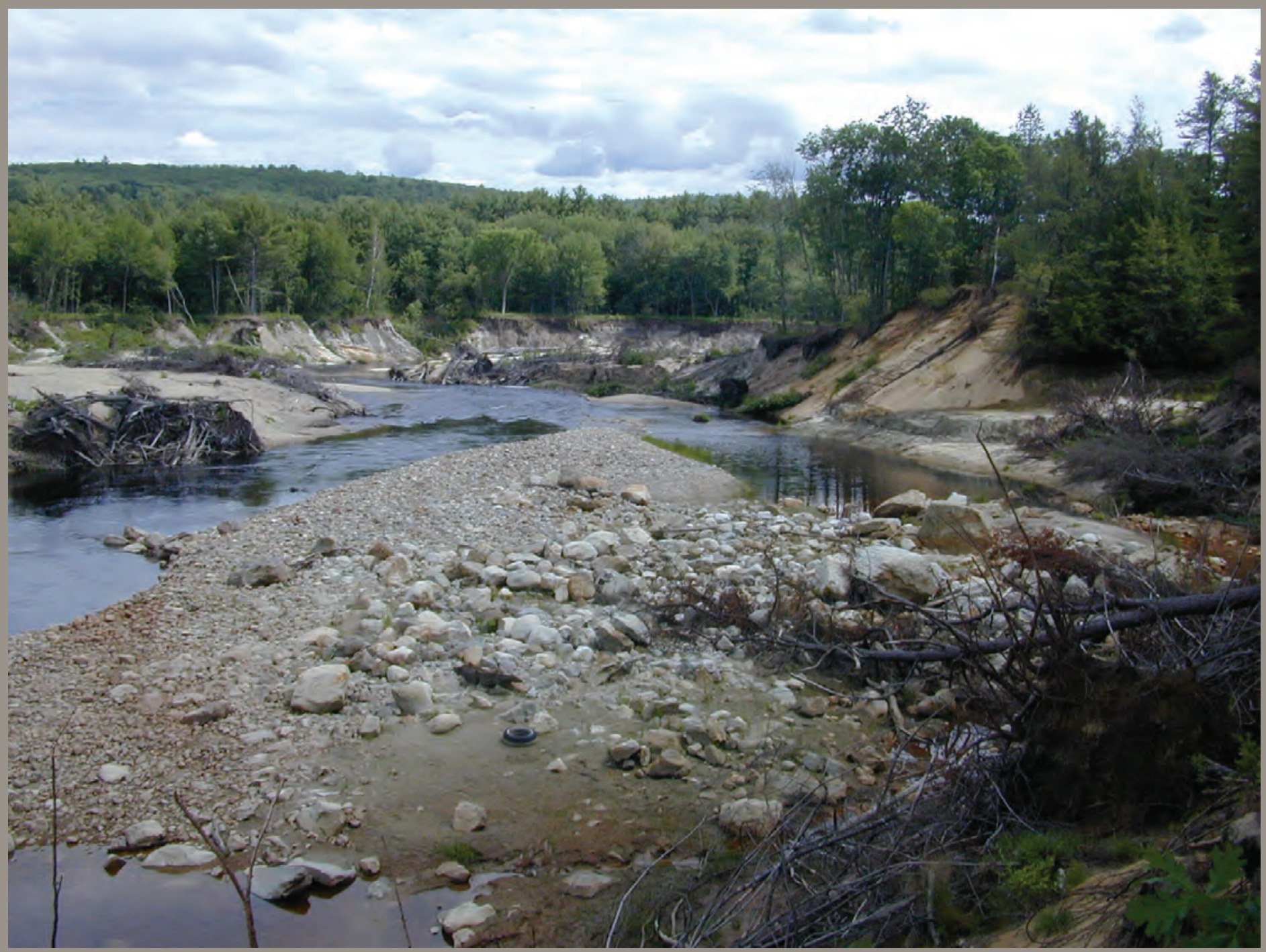

Scientific Investigations Report 2010-5127

U.S. Department of the Interior

U.S. Geological Survey 
Cover. Photograph looking downstream at area of Suncook River avulsion, Epsom, New Hampshire. (Photograph taken on June 18, 2008) 


\section{Flood Study of the Suncook River in Epsom, Pembroke, and Allenstown, New Hampshire, 2009}

By Robert H. Flynn

Prepared in cooperation with the Federal Emergency Management Agency

Scientific Investigations Report 2010-5127 


\section{U.S. Department of the Interior \\ KEN SALAZAR, Secretary \\ U.S. Geological Survey \\ Marcia K. McNutt, Director}

U.S. Geological Survey, Reston, Virginia: 2010

For more information on the USGS - the Federal source for science about the Earth, its natural and living resources, natural hazards, and the environment, visit http://www.usgs.gov or call 1-888-ASK-USGS

For an overview of USGS information products, including maps, imagery, and publications, visit http://www.usgs.gov/pubprod

To order this and other USGS information products, visit http://store.usgs.gov

Any use of trade, product, or firm names is for descriptive purposes only and does not imply endorsement by the U.S. Government.

Although this report is in the public domain, permission must be secured from the individual copyright owners to reproduce any copyrighted materials contained within this report.

Suggested citation:

Flynn, R.H., 2010, Flood study of the Suncook River in Epsom, Pembroke, and Allenstown, New Hampshire, 2009: U.S. Geological Survey Scientific Investigations Report 2010-5127, 64 p. (Also available at http://pubs.usgs.gov/ sir/2010/5127.) 


\section{Acknowledgments}

The author would like to express appreciation to the following U.S. Geological Survey personnel who assisted with collection of data in this report-Richard Kiah, Scott Olson, Thor Smith, James Degnan, Chandlee Keirstead, Heather Manzi, and Glenn Berwick.

The author would like to acknowledge that the cost of generating the 1- and 4-ft contour interval data used in the creation of the flood mapping for this study was funded through a New Hampshire Department of Safety-Bureau of Emergency Management grant (Emergency Management Performance Grant) with in-kind matching funding provided by the New Hampshire Department of Environmental Services through its dam-maintenance efforts in the Suncook River watershed. 
THIS PAGE INTENTIONALLY LEFT BLANK 


\section{Contents}

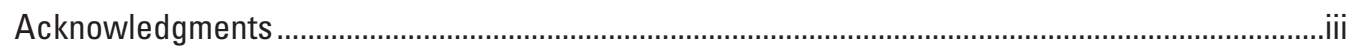

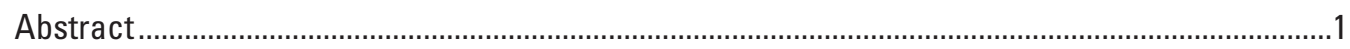

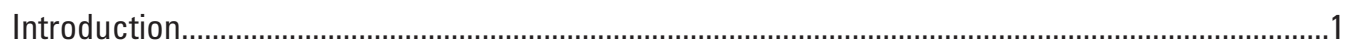

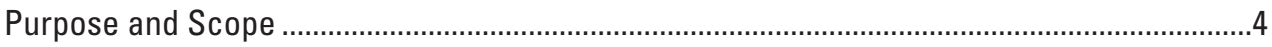

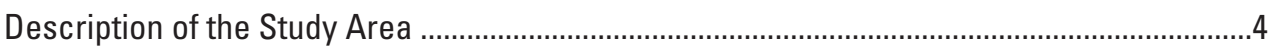

Flood Mapping and Flood-Plain Management Applications ...................................................

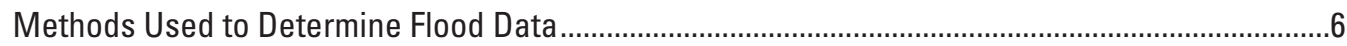

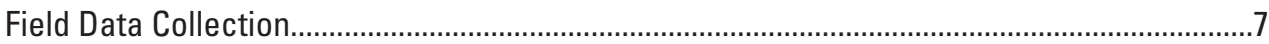

Indirect Determination of Peak Flow for the Suncook River Flood of April 2007 ......................7

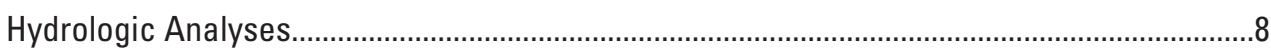

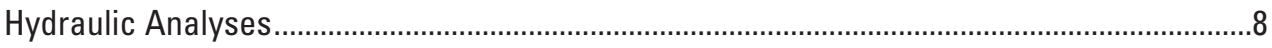

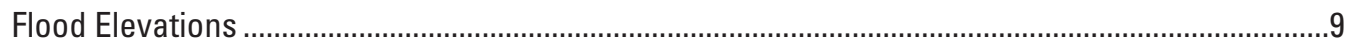

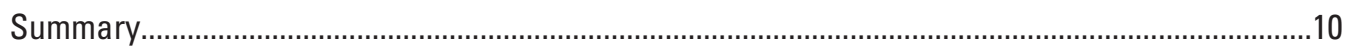

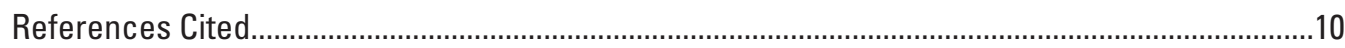

Appendix 1. Suncook River 10-, 2-, 1- and 0.2-Percent Annual Exceedance Probability Flood

Profiles (10-, 50-, 100-, and 500-Year Recurrence-Interval Floods, respectively)...............25

Appendix 2. Suncook River April 2007 Flood and 50-, 20-, and 4-Percent Annual Exceedance

Probability Flood Profiles (2-, 5-, and 25-Year Recurrence-Interval Floods, respectively) 39

Appendix 3. Elevation Reference Marks .............................................................................53

Appendix 4. Suncook River Flood Map of the Floodway, and the 100- and 500-Year Flood from the Confluence with the Merrimack River to the Upstream Corporate Limit of Epsom,

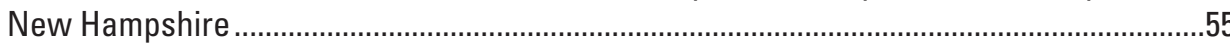

\section{Figures}

1. Map showing extent of the flood study of the Suncook River in Epsom, Pembroke, and Allenstown, NH..................................................................................................2

2. Pre-avulsion aerial imagery with the new and abandoned channels of the May 2006 Suncook River avulsion, Epsom, NH........................................................................

3. Map showing location of the Suncook River streamgage at North Chichester, NH (01089500), and indirect discharge locations for the determination of the April 2007 flood peak on the Suncook River ..................................................................................

\section{Tables}

1. Drainage areas and peak recurrence-interval flows for selected locations on the Suncook River in Epsom, Pembroke, and Allenstown, $\mathrm{NH}$

2. Cross sections and the 10-,50-, 100-, and 500-year recurrence-interval flood data for Suncook River in Epsom, Pembroke, and Allenstown, $\mathrm{NH}$..

3. Cross sections and the 2-, 5-, 25-year recurrence-interval and April 2007 flood data for Suncook River in Epsom, Pembroke, and Allenstown, NH...

4. Surveyed and HEC-RAS-modeled April 2007 elevations of flood high-water marks for the Suncook River, NH

5. $1978 \mathrm{FIS}$ and 2009 flood study 100 -year flood elevations for selected locations in the Suncook River in Epsom, Pembroke, and Allenstown, NH

6. Cross sections, 100-year recurrence-interval, and floodway data for Suncook River in Epsom, Pembroke, and Allenstown, $\mathrm{NH}$ 


\section{Conversion Factors, Datum, and Abbreviations}

\begin{tabular}{|c|c|c|}
\hline Multiply & By & To obtain \\
\hline \multicolumn{3}{|c|}{ Length } \\
\hline inch (in.) & 2.54 & centimeter $(\mathrm{cm})$ \\
\hline inch (in.) & 25.4 & millimeter $(\mathrm{mm})$ \\
\hline foot $(\mathrm{ft})$ & 0.3048 & meter $(\mathrm{m})$ \\
\hline mile (mi) & 1.609 & kilometer $(\mathrm{km})$ \\
\hline \multicolumn{3}{|c|}{ Area } \\
\hline square mile $\left(\mathrm{mi}^{2}\right)$ & 2.590 & square kilometer $\left(\mathrm{km}^{2}\right)$ \\
\hline \multicolumn{3}{|c|}{ Volume } \\
\hline cubic yard $\left(\mathrm{yd}^{3}\right)$ & 0.7646 & cubic meter $\left(\mathrm{m}^{3}\right)$ \\
\hline \multicolumn{3}{|c|}{ Flow rate } \\
\hline foot per second (ft/s) & 0.3048 & meter per second $(\mathrm{m} / \mathrm{s})$ \\
\hline cubic foot per second $\left(\mathrm{ft}^{3} / \mathrm{s}\right)$ & 0.02832 & cubic meter per second $\left(\mathrm{m}^{3} / \mathrm{s}\right)$ \\
\hline
\end{tabular}

Temperature in degrees Celsius $\left({ }^{\circ} \mathrm{C}\right)$ may be converted to degrees Fahrenheit $\left({ }^{\circ} \mathrm{F}\right)$ as follows:

$$
{ }^{\circ} \mathrm{F}=\left(1.8 x^{\circ} \mathrm{C}\right)+32
$$

Temperature in degrees Fahrenheit $\left({ }^{\circ} \mathrm{F}\right)$ may be converted to degrees Celsius $\left({ }^{\circ} \mathrm{C}\right)$ as follows:

$$
{ }^{\circ} \mathrm{C}=\left({ }^{\circ} \mathrm{F}-32\right) / 1.8
$$

Horizontal coordinate information is referenced to the North American Datum of 1983 (NAD 83).

Vertical coordinate information is referenced to the National Geodetic Vertical Datum of 1929 (NGVD 29).

OTHER ABBREVIATIONS USED IN REPORT

ADCP Acoustic Doppler Current Profiler

FEMA Federal Emergency Management Agency

FIRM Flood Insurance Rate Map

FIS Flood Insurance Study

GPS Global Positioning System

HEC-RAS Hydrologic Engineering Center River Analysis System

NFIP National Flood Insurance Program

NHDOT New Hampshire Department of Transportation

NWIS National Water Information System

USACE U.S. Army Corps of Engineers

USGS U.S. Geological Survey 


\title{
Flood Study of the Suncook River in Epsom, Pembroke, and Allenstown, New Hampshire, 2009
}

\author{
By Robert H. Flynn
}

\section{Abstract}

On May 15, 2006, a breach in the riverbank caused an avulsion in the Suncook River in Epsom, NH. The breach in the riverbank and subsequent avulsion changed the established flood zones along the Suncook River; therefore, a new flood study was needed to reflect this change and aid in flood recovery and restoration. For this flood study, the hydrologic and hydraulic analyses for the Suncook River were conducted by the U.S. Geological Survey, in cooperation with the Federal Emergency Management Agency.

This report presents water-surface elevations and profiles determined using the U.S. Army Corps of Engineers onedimensional Hydrologic Engineering Center River Analysis System model, also known as HEC-RAS. Steady-state watersurface profiles were developed for the Suncook River from its confluence with the Merrimack River in the Village of Suncook (in Allenstown and Pembroke, NH) to the upstream corporate limit of the town of Epsom, NH (approximately 15.9 river miles). Floods of magnitudes that are expected to be equaled or exceeded once on the average during any 2-, 5-, 10-, 25-, 50-, 100-, or 500-year period (recurrence interval) were modeled using HEC-RAS. These flood events are referred to as the 2-, 5-, 10-, 25-, 50-, 100-, and 500-year floods and have a 50-, 20-, 10-, 4-, 2-, 1-, and 0.2-percent chance, respectively, of being equaled or exceeded during any year. The 10-, 50-, 100-, and 500-year flood events are important for flood-plain management, determination of floodinsurance rates, and design of structures such as bridges and culverts. The analyses in this study reflect flooding potentials that are based on existing conditions in the communities of Epsom, Pembroke, and Allenstown at the time of completion of this study (2009). Changes in the 100-year recurrenceinterval flood elevation from the 1979 flood study were typically less than 2 feet with the exception of a location 900 feet upstream from the avulsion that, because of backwater from the dams in the abandoned channel, was 12 feet higher in the 1979 flood study than in this study.

\section{Introduction}

The Suncook River drains a group of lakes to the south of Lake Winnipesaukee and flows for approximately $30 \mathrm{mi}$ to the Merrimack River at a location between Concord and Manchester, NH (fig. 1). Floods typically occur along the Suncook and Little Suncook Rivers during the spring, fall, and winter. Some of the most severe flooding in early spring is a result of snowmelt and heavy rains in conjunction with river ice. Major flooding in the fall is a result of heavy rainfall associated with tropical storms. Large thunderstorms can result in rapid runoff and flooding in the downstream reaches of small streams.

Two floods in March 1936 resulted in the largest flood of record for the Suncook River. A combination of saturated ground, warm temperatures, snowmelt, and heavy rains from the second flood, following the filling of lakes and reservoirs and high river flows from the first flood, resulted in a peak flow of $12,900 \mathrm{ft}^{3} / \mathrm{s}$ at the U.S. Geological Survey (USGS) streamgage Suncook River at Depot Road in North Chichester, NH (streamgage number 01089500), hereinafter referred to as the Suncook River streamgage. The March 1936 peak flow was determined to be between a 100- and 500-year event (Flynn, 2008; Olson, 2007) and remains the largest flood of record at the Suncook River streamgage.

From May 13 to 16, 2006, central and southern New Hampshire were flooded as a result of rainfall in excess of 8.8 in. (measured in Concord, $\mathrm{NH}$ ) over a 4-day period. During the storm, flooding, along with streambed and streambank erosion and deposition, was substantial at several locations in the state. As a result of the flood damage, a presidential disaster declaration was made on May 25, 2006, for the New Hampshire counties of Rockingham, Hillsborough, Strafford, Merrimack, Belknap, Carroll, and Grafton. In response to this declaration, the USGS, in cooperation with the Federal Emergency Management Agency (FEMA), measured or computed flood data at 65 streamgages within the disaster declaration area (Olson, 2007). On the basis of surveyed high-water marks, the peak flow at the Suncook River streamgage for the May 2006 event was determined to be 7,600 $\mathrm{ft}^{3} / \mathrm{s}$ (Olson, 2007), the third largest flood of record at this streamgage. This flow was determined from the Suncook 


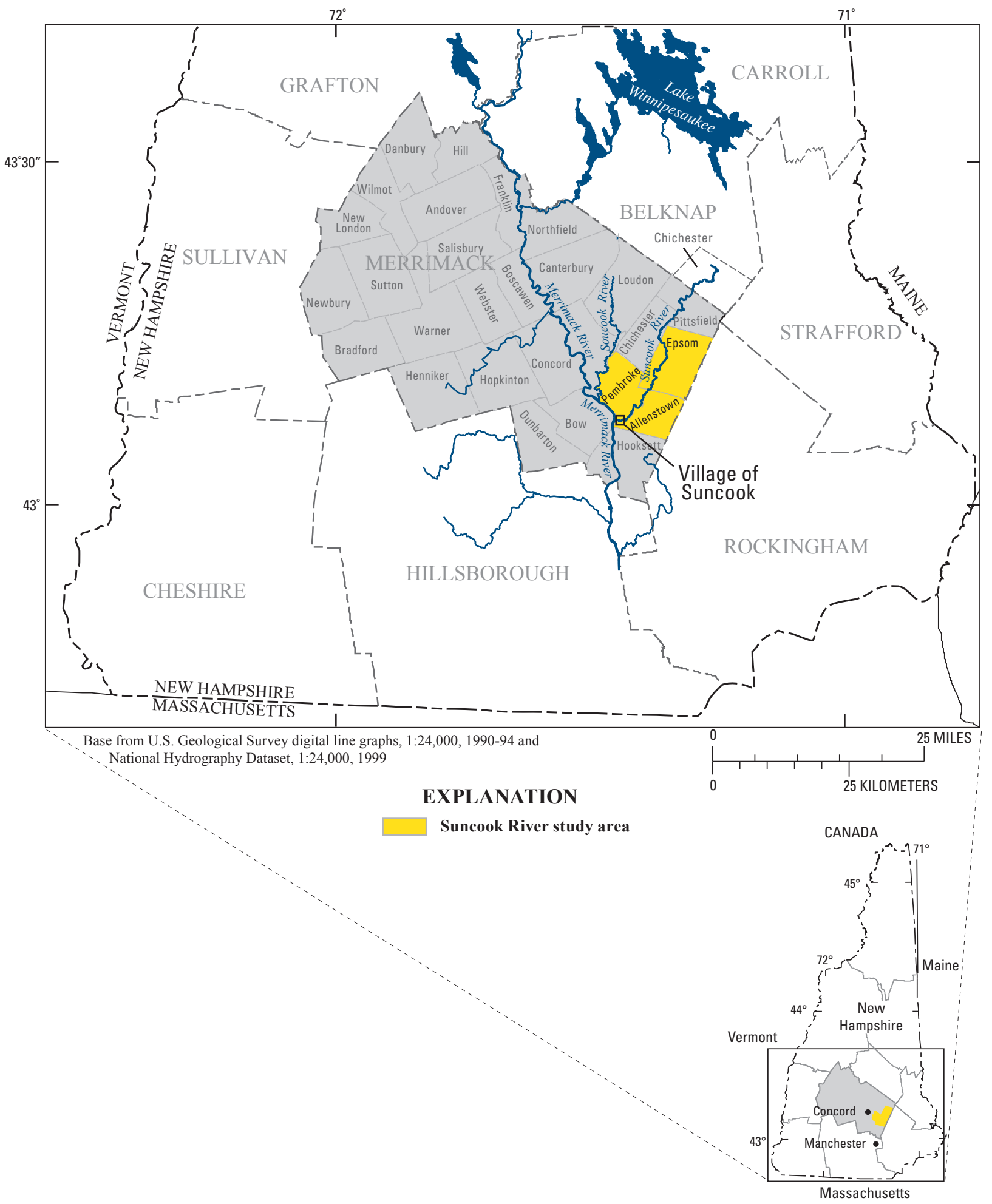

Figure 1. Extent of the flood study of the Suncook River in Epsom, Pembroke, and Allenstown, NH. 
River streamgage rating curve (stage/flow relation) that was extended above $4,500 \mathrm{ft}^{3} / \mathrm{s}$ on the basis of a slope-area and contracted-opening measurement at $15.27 \mathrm{ft}$ for the flood peak of 12,900 $\mathrm{ft}^{3} / \mathrm{s}$ on March 19, 1936.

On May 15, 2006, a breach in the riverbank south of U.S. Route 4 and east of State Route 28 created an avulsion in the Suncook River in Epsom, NH (fig. 2). An avulsion refers to the abandonment of a river channel and the formation of a new river channel. Prior to the breach, the Suncook River flowed southward around Bear Island in Epsom, NH, in two stream reaches that joined to the west of Round Pond. The breach during the May 2006 flood created a new channel upstream from Bear Island and two dams at the north end of Bear Island, with the new channel rejoining the old channel to the east of Bear Island. After May 16, there was no flow in the western and northeastern reach of the Suncook River around Bear Island. Instead, the Suncook River created a path through a gravel and sand pit resulting in a channel to the east of its former location (fig. 2). The new channel through the former gravel and sand pit created by the breach of May 15, 2006, was $0.42 \mathrm{mi}(2,220 \mathrm{ft})$ in length, whereas the abandoned primary east channel was $0.87 \mathrm{mi}(4,595 \mathrm{ft})$ in length. The abandoned west channel was $1.14 \mathrm{mi}(6,040 \mathrm{ft})$ in length; the total length of abandoned channel was $2.01 \mathrm{mi}$. The length of the new channel of the Suncook River from the location upstream from the former confluence with the abandoned channel (upstream from the avulsion), through the former sand and gravel pit, back into the east channel and to the downstream location of the confluence at the abandoned west channel (southern end of Bear Island) was $1.02 \mathrm{mi}$ $(5,407 \mathrm{ft})$. As a result of the reduction in total stream length, from 2.01 to $1.02 \mathrm{mi}$, the average gradient of the Suncook River increased approximately 40 percent between the upstream and downstream locations of the abandoned channels. Because of this increased gradient, the average velocity of the river will increase, which is expected to increase the ability of the river to erode the riverbed and banks.

The breach and subsequent avulsion also affected sediment induction into the Suncook River because of the new path of the river through the sand and gravel pit. It was estimated that $150,000 \mathrm{yd}^{3}$ of sediment were introduced into the Suncook River as a result of the new channel (Wittkop,

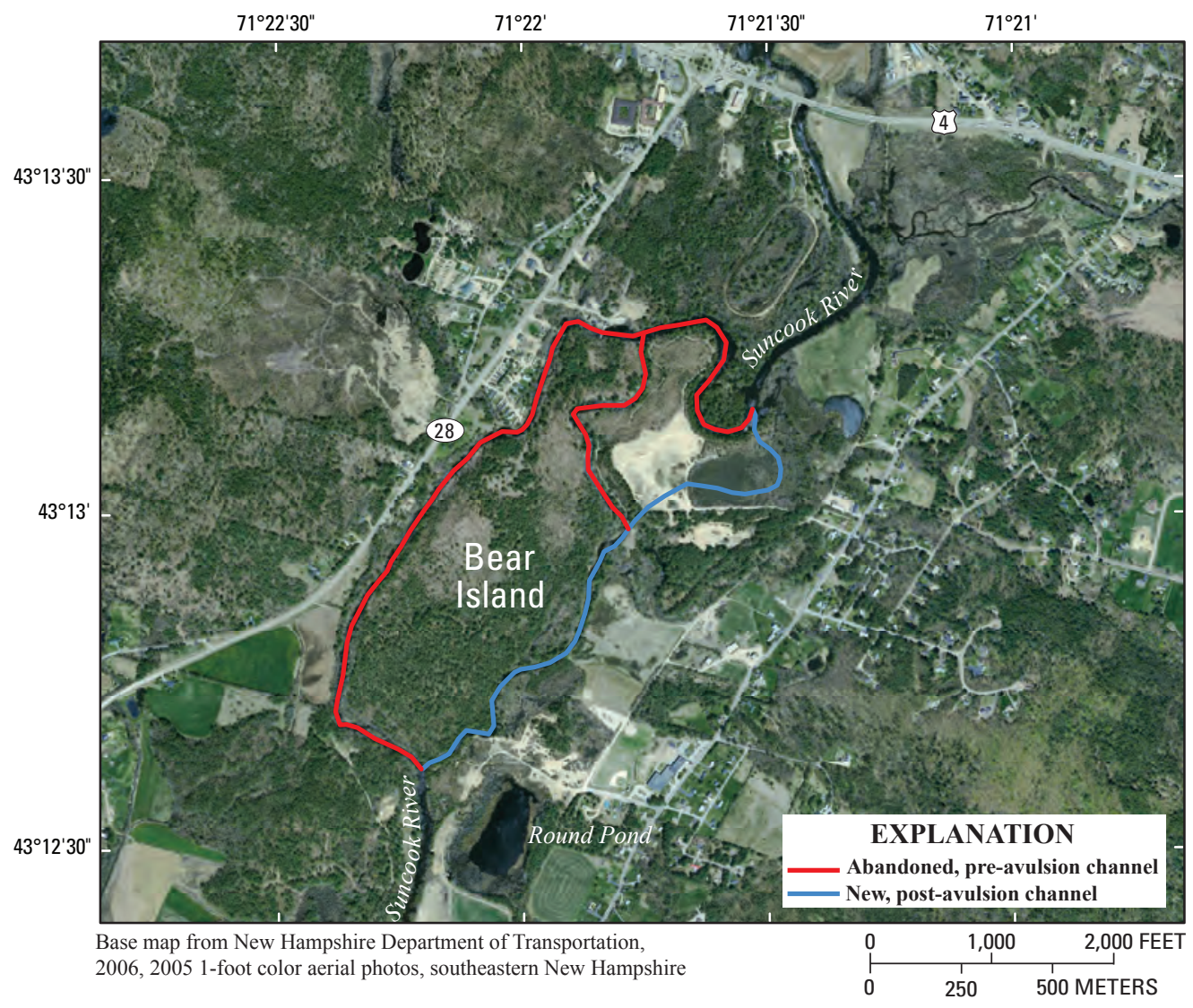

Figure 2. Pre-avulsion aerial imagery with the new and abandoned channels of the May 2006 Suncook River avulsion, Epsom, NH. 
2006). Sheets of silt and sand, up to $5 \mathrm{ft}$ thick, were deposited downstream from the avulsion channel, and this deposition is expected to decrease channel depth and increase the frequency of overbank flooding. In the avulsion area and upstream, downcutting of the stream continues to occur because of the increased gradient of the Suncook River and the convergence of flow.

From April 16 to 18, 2007, southeastern New Hampshire experienced severe flooding as a result of a storm that stalled off the New England coast and deposited, in some locations, more than 7 in. of rainfall on an existing snowpack. As a result of this flood event, a presidential disaster declaration was made for Grafton, Hillsborough, Merrimack, Rockingham, and Strafford Counties in New Hampshire. On May 10, 2007, Belknap County was added to the disaster declaration. In response to this declaration, the USGS, in cooperation with FEMA, measured or computed flood data at 57 streamgages and 4 ungaged locations within and adjacent to the disaster areas (Flynn, 2008). On the basis of hydraulic models calibrated with surveyed high-water marks, the peak flow at the USGS Suncook River streamgage for the April 2007 event was determined by indirect methods to be $10,600 \mathrm{ft}^{3} / \mathrm{s}$ and to have a recurrence interval of between 100 and 500 years (Flynn, 2008). This flood peak was the second largest flood of record at this streamgage. The May 2006 flood peak was subsequently estimated to be $6,600 \mathrm{ft}^{3} / \mathrm{s}$ on the basis of the original rating curve extended with the April 2007 peak. The 2006 peak flow was determined to have a recurrence interval of between 25 and 50 years. The May 2006 and April 2007 flood peaks were listed by the USGS as "extremes outside period of record."

Although the recurrence interval represents the longterm average period between floods of a specific magnitude, floods can recur at short intervals and within the same year. The probability of experiencing a flood of a given magnitude increases when periods greater than 1 year are considered. For example, the probability of a flood that equals or exceeds the 100 -year flood (1-percent chance of annual exceedance) in any 50 -year period is approximately 40 percent (4 in 10), and for any 90 -year period, the probability increases to approximately 60 percent (6 in 10). The analyses reported herein reflect flooding potentials that are based on conditions in the communities at the time this study was completed (2009).

The breach in the riverbank and subsequent avulsion changed the established flood zones along the Suncook River as defined by the U.S. Department of Housing and Urban Development Federal Insurance Administration (1978a, 1978b, 1978c); therefore, new flood maps were needed to reflect this change to the impact of the Suncook River on property and homes in the communities along the river. The current effective FEMA Flood Insurance Rate Maps (FIRMs) and Flood Insurance Studies (FISs) for Allenstown (U.S. Department of Housing and Urban Development Federal Insurance Administration, 1978a), Epsom (U.S. Department of Housing and Urban Development Federal Insurance Administration, 1978b) and Pembroke (U.S. Department of Housing and Urban Development Federal Insurance Administration, 1978c) contain detailed 100- and 500-year flood-hazard areas that are no longer valid because of the breach and updated hydrology and topographic data, and need to be updated. This flood study to update the 100- and 500 -year flood elevations was conducted by the USGS in cooperation with FEMA. Updated elevations and flood-plain maps for the Suncook River can be used by state and local officials to guide the redevelopment and replacement of damaged infrastructure and the allocation of state and federal recovery resources, and to ensure that effective mitigation measures are in place to avoid future flood losses.

\section{Purpose and Scope}

This report provides updated flood elevations for the Suncook River as a result of the May 2006 and April 2007 floods and the May 2006 avulsion. This study area included the Suncook River from the confluence with the Merrimack River to the upstream corporate limit of the town of Epsom (15.9 mi) in Merrimack County, NH (fig. 1). The results of this study may be used to update the previous FISs and FIRMs for the towns of Allenstown, Epsom, and Pembroke, NH (U.S. Department of Housing and Urban Development Federal Insurance Administration, 1978a, 1978b, 1978c; respectively), and may be used to update existing flood-plain regulations as part of the National Flood Insurance Program (NFIP). The information also can be used by local and regional planners to further promote sound land use and flood-plain development.

Floods that are expected to be equaled or exceeded once on the average during any 10-, 50-, 100-, or 500-year period (recurrence interval) have been recognized as having special importance for flood-plain management and for floodinsurance rates and were modeled in this study. These events, commonly termed the 10-, 50-, 100-, and 500-year floods, have a 10-, 2-, 1-, and 0.2-percent chance, respectively, of being equaled or exceeded during any year. In addition, the 2-, 5-, and 25-year (recurrence interval) flood events and the peak flood of April 16-18, 2007, were modeled in this study. The 2-, 5-, and 25-year floods have a 50-, 20-, and 4-percent chance, respectively, of being equaled or exceeded during any year.

\section{Description of the Study Area}

The Suncook River flows through the towns of Epsom, Pembroke, and Allenstown, NH, in southeastern Merrimack County, which is in south-central New Hampshire (fig. 1). State Route 28 is parallel to the Suncook River and connects the towns of Epsom, Pembroke, and Allenstown. The Suncook River originates to the south of Lake Winnipesaukee, is approximately $39 \mathrm{mi}$ long, and flows in a southerly direction. Its confluence with the Merrimack River is in the Village of Suncook, NH, which is located within the towns of Allenstown and Pembroke, NH. The drainage area is $154 \mathrm{mi}^{2}$ 
at the USGS Suncook River streamgage in North Chichester, $\mathrm{NH}$, and $255.7 \mathrm{mi}^{2}$ at the confluence of the Suncook River with the Merrimack River in the Village of Suncook, NH.

The town of Epsom comprises $34.5 \mathrm{mi}^{2}$ of land area and $0.1 \mathrm{mi}^{2}$ of inland water area. The population of Epsom was 4,567 in 2007 (New Hampshire Employment Security, Economic and Labor Market Information Bureau, 2009b) or approximately 132 people per square mile. The population of Epsom increased 66 percent between 1980 and 2007.

The town of Pembroke includes the Villages of North Pembroke and Suncook and comprises $22.6 \mathrm{mi}^{2}$ of land area and $0.2 \mathrm{mi}^{2}$ of inland water area. The population of Pembroke was 7,353 in 2007 (New Hampshire Employment Security, Economic and Labor Market Information Bureau, 2009c) or approximately 322 people per square mile. The population of Pembroke increased 51 percent between 1980 and 2007.

The town of Allenstown includes the Village of Suncook and comprises $20.5 \mathrm{mi}^{2}$ of land area and $0.1 \mathrm{mi}^{2}$ of inland water area. The population of Allenstown was 4,943 in 2007 (New Hampshire Employment Security, Economic and Labor Market Information Bureau, 2009a) or approximately 240 people per square mile. The population of Allenstown increased 12 percent between 1980 and 2007.
The Little Suncook River, a tributary to the Suncook River, originates east of Epsom at Northwood Lake and flows westerly to its confluence with the Suncook River downstream from U.S. Route 4 (fig. 3). The drainage area at the mouth of the Little Suncook River is approximately $41 \mathrm{mi}^{2}$ (U.S. Department of Housing and Urban Development Federal Insurance Administration, 1978b). Numerous other small streams flow into these two rivers. In general, the flood plains along the Suncook and Little Suncook Rivers are sparsely developed with the exception of areas near the intersection of the Suncook River and U.S. Route 4, the intersection of the Suncook River and U.S. Route 3, downstream through the Village of Suncook, and near Gossville and Epsom along the Little Suncook River.

The prevailing winds in Epsom, Pembroke, and Allenstown are from the northwest and result in cold, dry air in the winter and cool, dry air in the summer. Strong winds from the south occur in July and August, and winds from the east typically coincide with summer and winter storms (National Climate Data Center, 2008). Precipitation falls on an average of 1 day out of 3 during the year; the frequency is slightly higher for April and May and slightly lower for August to October. Easterly winds and especially northeasterly

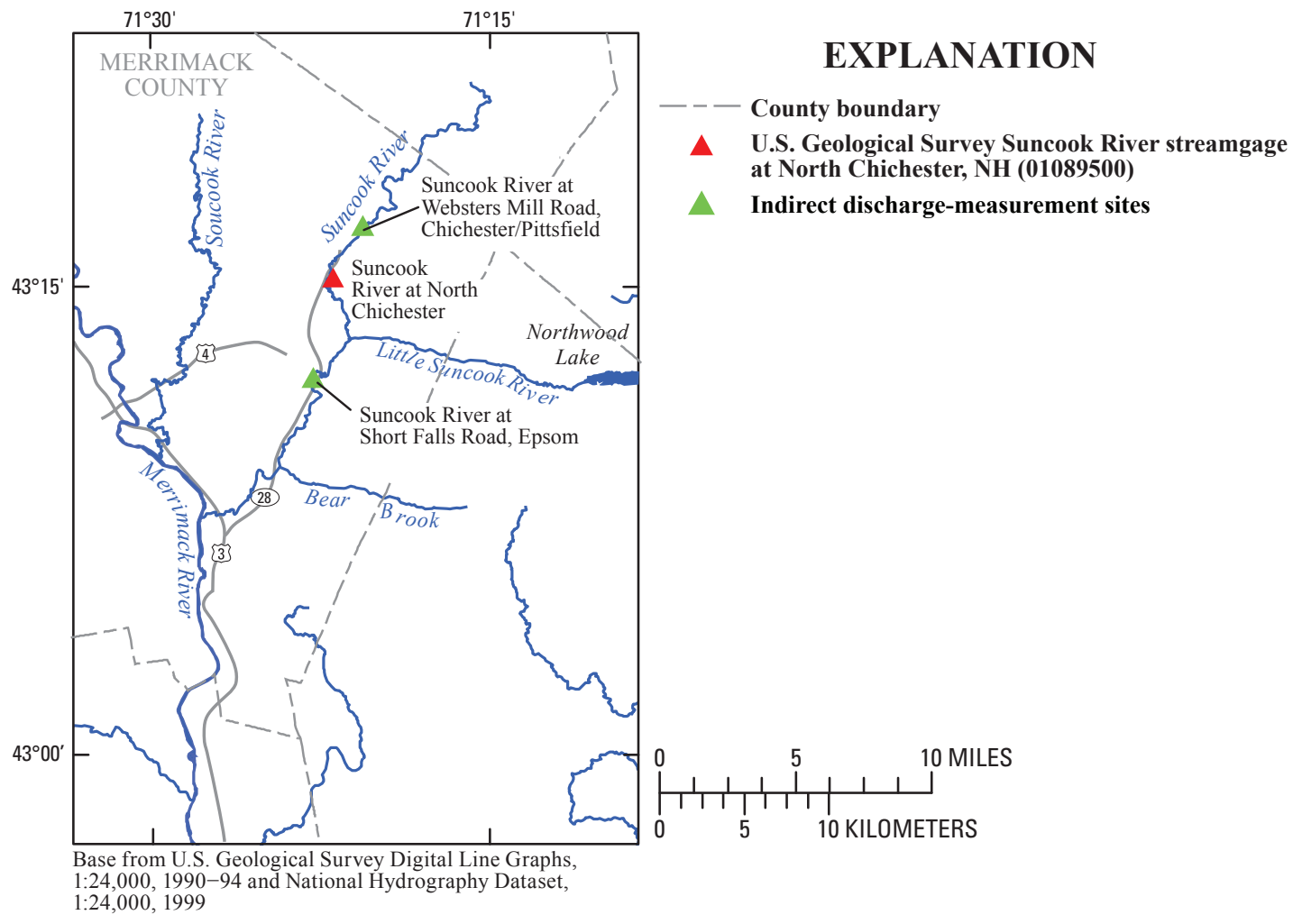

Figure 3. Location of the Suncook River streamgage at North Chichester, NH (01089500), and indirect discharge locations for the determination of the April 2007 flood peak on the Suncook River. 
winds are associated with the more substantial rains and heavier snowfalls. Snow cover typically lasts from midDecember until the last week of March, although bare ground is not a rarity in the winter. Rain, sleet, or freezing rain may also occur during the winter (National Climate Data Center, 2008).

The average daily maximum and minimum temperatures for July in Concord, $\mathrm{NH}$, are 82.2 and $57.2^{\circ} \mathrm{F}$, respectively. The average daily maximum and minimum temperatures for January in Concord are 31.1 and $10.7^{\circ} \mathrm{F}$, respectively. Average annual precipitation in Concord for 1979-2008 (rain, snow, and sleet) is $37.9 \mathrm{in}$. Average annual snowfall in Concord for 1979-2008 is 63.8 in. (National Climate Data Center, 2008).

The topography of Epsom, Pembroke, and Allenstown is hilly and characterized by stratified and unstratified material transported by and deposited from retreating glacial ice. The flood plains adjacent to the rivers are comprised of alluvial silt overlying glacial outwash. The predominant soil group is composed primarily of well-drained sandy loam in glacial till. Kames, terraces, deltas, and outwash plains are glacial landforms common to this area. Elevations range from $192 \mathrm{ft}$ (NGVD 29) at the confluence of the Suncook and Merrimack Rivers to 1,413 ft (NGVD 29) at the summit of Fort Mountain in Epsom. Wetland areas throughout the three towns serve as the headwaters for many smaller streams.

The Suncook River has no major flood-control structures. The Pittsfield Mill Dams in Pittsfield, NH, Buck Street Dam in Pembroke, NH, and Webster, Pembroke, and China Mill Dams in the Village of Suncook are all run-of-river dams and do not act as flood-control dams. The Webster, Pembroke, and China Mill Dams are used for hydroelectric power generation. These dams do little to attenuate major flood peaks.

\section{Flood Mapping and Flood-Plain Management Applications}

The 100- and 500-year flood-plain and floodway boundaries have been delineated using the flood elevations determined at 160 cross sections along the river. To provide a national standard without regional discrimination, the 1-percent annual exceedance probability (100-year) flood has been adopted by FEMA as the base flood for purposes of flood-plain management. The 0.2-percent annual exceedance probability (500-year) flood is used to indicate additional areas of flood risk in the community.

The floodway is the channel of a stream plus any adjacent flood-plain areas that must be kept free of encroachment so that the 100-year recurrence-interval flood can be carried without substantial increases in flood heights. Minimum federal standards limit such increases to $1.0 \mathrm{ft}$ provided that hazardous velocities are not produced. The floodway presented in this study was computed for certain stream segments on the basis of equal conveyance reduction from each side of the flood plain. Floodway widths were computed at cross sections. Encroachment on flood plains, such as structures and fill, reduces flood-carrying capacity, increases flood heights and velocities, and increases flood hazards in areas beyond the encroachment itself. One aspect of flood-plain management involves balancing the economic gain from flood-plain development against the resulting increase in flood hazard. For purposes of the NFIP, delineation of a floodway can assist local communities in this aspect of flood-plain management.

The floodways in this study are presented as a minimum standard that can be adopted directly by the towns. The area between the floodway and 100-year flood-plain boundaries is termed the floodway fringe. The floodway fringe encompasses that part of the flood plain that could be completely obstructed without increasing the water-surface elevation of the 100-year flood by more than $1.0 \mathrm{ft}$ at any point.

The 1-ft contour-interval data (Eastern Topographics, 2007) were created for the reach of the Suncook River from U.S. Route 4 to approximately $0.25 \mathrm{mi}$ downstream from the Short Falls Road bridge. These 1-ft contour-interval data extended out to $660 \mathrm{ft}$ on either side of this reach. The 4-ft contour-interval data (Eastern Topographics, 2008) were created for the reach of the Suncook River from the Short Falls Road bridge to the confluence with the Merrimack River. These 4-ft contour-interval data extended out to $1,000 \mathrm{ft}$ on either side of the Suncook River. In areas beyond the extent of the 1- and 4-ft contour-interval data, 10- and 20-ft contour interval USGS Digital Orthophoto Quadrangles produced at a scale of 1:24,000 referenced to the horizontal datum of NAD 83 and the vertical datum of NGVD 29 (U.S. Geological Survey, 1967a, 1967b, 1968, 1981) were used to delineate the extent of flooding on the 100- and 500-year flood map for the Suncook River.

The base map for the delineation of the floodway and the 100- and 500-year floods (appendix 4) was created using black and white aerial photographic imagery collected by Eastern Topographics (2007) in May 2007 (post-avulsion) along the Suncook River and 1-ft-resolution color aerial photographic imagery of southeastern New Hampshire (New Hampshire Department of Transportation, 2006) collected for the New Hampshire Department of Transportation (NHDOT) in May 2005 (pre-avulsion) for areas outside the extent of the Eastern Topographics (2007) imagery.

\section{Methods Used to Determine Flood Data}

Hydrologic and hydraulic analyses were used to determine the flood data required for this flood study of the Suncook River. The U.S. Army Corps of Engineers (USACE) step-backwater flow model, Hydrologic Engineering Center River Analysis System model (HEC-RAS) (U.S. Army Corps of Engineers, 2008a), was used for the determination of water-surface elevations at surveyed cross sections and, subsequently, flood profiles for the selected recurrence-interval floods along the study reach. The water-surface elevations determined with HEC-RAS were used to create the flood map 
delineating the extent of the 100- and 500-year floods. Input for the HEC-RAS model required the collection of hydraulic and hydrologic field data to characterize channel geometry and flow. Hydraulic data included river cross-section surveys at 160 locations and structural surveys at 7 bridges and 5 inline (dam) structures. Hydrologic data included analysis of streamflow data from the Suncook River streamgage that incorporated peak-flow data determined by indirect methods in 2006 and 2007 (Olson, 2007; Flynn, 2008; respectively). The Suncook River HEC-RAS model was calibrated to the flood of April 2007 using high-water-mark data collected after that flood along with the flood peak flow determined by indirect methods at the Suncook River streamgage.

All FISs and FIRMs are referenced to a specific vertical datum. The vertical datum provides a starting point against which flood, ground, and structure elevations can be referenced and compared. All structure, ground, and flood elevations given in this flood-study report and map are referenced to the NGVD 29, unless otherwise noted. The coordinate system used for the production of the digital flood map is New Hampshire State Plane referenced to the NAD 83 and NGVD 29. A description of the reference marks used in this study is presented in appendix 3 .

\section{Field Data Collection}

After the April 16-18, 2007, flood, high-water-mark information, indicating peak flood stage, was collected upstream from, downstream from, and at the former USGS Suncook River streamgage (Flynn, 2008). The high-water marks consisted of debris lines, wash lines, seed lines, or mud/silt lines left behind by the peak water elevation during the flood. The peak-flood-stage data at flagged high-water marks and field-surveyed cross sections were referenced to NGVD 29 through closed level-loop surveying techniques from either a known reference datum or from a reference datum established using a Leica System 1200 Global Positioning System (GPS) with 3-mm (0.01-ft) horizontal accuracy and $10-\mathrm{mm}(0.03-\mathrm{ft})$ vertical accuracy in static mode (Leica Geosystems, 2008).

Cross sections for the 15.9-mi study reach of the Suncook River were from field surveys conducted in the summer of 2008. Valley and below-water cross-section data for the Suncook River were obtained from field measurements. Additional valley cross-section data were obtained using 1-ft (Eastern Topographics, 2007) and 4-ft (Eastern Topographics, 2008) contour-interval data created from aerial photogrammetry collected in May 2007 and April 2008. All bridges, dams, and culverts were field-surveyed to obtain elevation data and structural geometry. Bridge, dam, and culvert cross-section data were collected at close intervals upstream and downstream from bridges and dams in order to compute the potential backwater effects of these structures. Between the Short Falls Road bridge and the Buck Street Dams, cross-section and profile data were collected using a
GPS in conjunction with an Acoustic Doppler Current Profiler (ADCP) (Mueller and Wagner, 2009).

\section{Indirect Determination of Peak Flow for the Suncook River Flood of April 2007}

The Suncook River streamgage was active from 1919 to 1920, 1922 to 1927, and 1929 to 1977. Because the Suncook River streamgage was inactive from 1978 to October 2007, it was not active during the two peak-flow events in May 2006 and April 2007 but was re-activated in November 2007. After the May 2006 and April 2007 floods, high-water-mark information was collected by the USGS at the Suncook River streamgage (Olson, 2007; Flynn, 2008). These data were used to estimate the flood peak flow for these events on the basis of the rating curve established for the streamgage for the period of record prior to 1977. Additional high-water-mark information was collected upstream and downstream from the Suncook River streamgage after the April 2007 flood (Flynn, 2008).

Initially, a peak flow of $15,000 \mathrm{ft}^{3} / \mathrm{s}$ was extrapolated for the April 16-18, 2007, flood at the Suncook River streamgage on the basis of the high-water-mark data and the rating curve. Subsequently, determinations of indirect flow were made at locations upstream and downstream from the discontinued streamgage, and a flow of $10,600 \mathrm{ft}^{3} / \mathrm{s}$ was determined to be the peak flow for the April 16-18, 2007, flood at the Suncook River streamgage (Flynn, 2008). This peak flow was estimated at this streamgage on the basis of the flow/drainage-area relations between two indirectly determined (Matthai, 1967) April 2007 flood-peak flows. The April 2007 flood-peak indirect flow determinations were made at the Websters Mill Road bridge in Chichester/Pittsfield and at the Short Falls Road bridge in Epsom (fig. 3), which have drainage areas of 137 and $210 \mathrm{mi}^{2}$, respectively. The high-water marks upstream and downstream from each bridge, the bridgeopening geometry, and channel and flood-plain cross sections upstream and downstream from the bridge were surveyed, and the values were input to the HEC-RAS model. Flows were selected iteratively as input to the HEC-RAS model (U.S. Army Corps of Engineers, 2005) so that the resulting watersurface elevation output from the program matched the highwater marks surveyed upstream and downstream from each of the bridges. The upper end of the rating curve (stage/discharge relation) at the Suncook River streamgage has likely shifted since it was determined from the March 19, 1936, flood data when a flow of $12,900 \mathrm{ft}^{3} / \mathrm{s}$ at a gage height of $15.27 \mathrm{ft}$ was ascertained by slope-area and contracted-opening methods. The shift in the upper end of the stage/discharge rating curve is likely because of a greater amount of vegetation on the right overbank in 2007 than in 1936 (as seen in USGS photographs on file at the New Hampshire-Vermont Water Science Center) and the construction of a weir control along with the removal of a channel island downstream from the Suncook River streamgage in the summer of 1937. 


\section{Hydrologic Analyses}

Hydrologic analyses were used to establish the peak flowfrequency relations for the Suncook River. For this flood study, peak-flow frequencies for the Suncook River were estimated by Flynn (2008) using a log-Pearson Type III analysis described in Bulletin 17B "Guidelines for Determining Flood Flow Frequency" (U.S. Interagency Advisory Committee on Water Data, 1982). Bulletin 17B provides procedures for weighting station skews, for determining historical peaks, and for detecting and treating outliers and trends. Data from the USGS Suncook River streamgage were used for computing the frequency curve. The USGS computer program PeakFQ (U.S. Geological Survey, 2008a) was used to analyze peakflow frequency. The peak-flow data used as input to the PeakFQ program were retrieved from the National Water Information System (NWIS) (U.S. Geological Survey, 2008b).

To determine the peak flow-frequency curves for selected Suncook River locations, the relation between drainage areas at the streamgage and the ungaged locations (equation 1) was determined and applied to the log-Pearson Type III peak flowfrequency curve determined at the Suncook River streamgage.

$$
Q / Q_{g}=\left(A / A_{g}\right)^{n},
$$

where,

$\begin{array}{cl}Q & \text { is the flow at the ungaged site, } \\ Q_{g} & \text { is the flow at the USGS streamgage, } \\ A & \text { is the drainage area at the ungaged site, } \\ A_{g} & \text { is the drainage area at the USGS streamgage, } \\ n & \text { and } \\ n & \text { is the drainage-area adjustment value of } 0.94 .\end{array}$

The exponent $n$ in equation 1 was determined through a drainage-area relation between two indirectly determined April 2007 peak flows at locations upstream and downstream from the Suncook River streamgage (Flynn, 2008).

\section{Hydraulic Analyses}

Analyses of the hydraulic characteristics of flooding were carried out to provide estimates of the elevations of floods at the selected recurrence intervals. The hydraulic analyses for this study were based on an assumption of unobstructed flow. As a result, the flood elevations shown in the profiles are considered valid if hydraulic structures remain unobstructed, operate properly, and do not fail. Starting water-surface elevations for the Suncook River HEC-RAS (U.S. Army
Corps of Engineers, 2008a) flood model were based on normal-depth analysis, which is the depth at which flow is steady and hydraulic characteristics are uniform. The model computational procedure is based on the solution of the onedimensional energy equation (U.S. Army Corps of Engineers, 2008b). Energy losses are evaluated by friction (Manning's equation) and contraction and expansion. The momentum equation is used in situations where the water surface is rapidly varied. These situations include mixed flow-regime calculations (i.e., hydraulic jumps), hydraulics of bridges, and evaluating profiles at river confluences (stream junctions). In those areas where the analysis indicated supercritical flow conditions, critical depth was assumed for the flood elevation because of the inherent instability of supercritical flow. The Suncook River HEC-RAS flood model was calibrated using 22 high-water marks flagged and surveyed along the Suncook River (table 4) following the flood of April 2007 (Flynn, 2008).

Manning's “ $~ n$ " roughness factors (Barnes, 1967; Arcement and Schneider, 1989), used in the hydraulic computations, were assigned on the basis of engineering judgment and field observations of the stream and flood-plain areas. The channel and overbank Manning's " $n$ " values for the Suncook River study reach ranged from 0.02 to 0.09 in the channel and from 0.02 to 0.12 on the channel overbanks.

The Suncook River flood-study base-map elevations for the 100-year recurrence-interval flood elevations (also known as the base flood elevation or BFE) were compared to the 1978 FIS 100-year recurrence-interval floods elevations at selected locations (table 5). It is important to note that the Suncook River channel elevations have changed in many locations downstream from the avulsion since the 1978 FISs due to several factors, including newer techniques and methods in the HEC-RAS step-backwater model. Other factors affecting the channel elevations and the delineation of flood boundaries for the selected recurrence-interval floods in this flood study are:

- The peak discharges for the selected recurrenceinterval floods have been updated since the 1978 FIS with additional flow data available at the Suncook River streamgage,

- 1- and 4-ft contour-interval data were used for flood delineation in this study; the 1978 FIS used the bestavailable mapping of 20 -ft contour-interval data,

- More detailed field-survey information was collected at the structures and in the channel and a greater number of cross sections were surveyed in the field in 2008 than for the 1978 FISs. 


\section{Flood Elevations}

Suncook River flood-study drainage areas and peak flows adjusted for selected locations on the Suncook River that were used as input for the HEC-RAS model are given in table 1. Suncook River streamgage peak recurrence-interval flows were determined in a previous study (Flynn, 2008).

The resulting flood elevations from the HEC-RAS flood analyses for the Suncook River are shown in table 2 and appendix 1 for the 10-, 50-, 100-, and 500-year recurrenceinterval floods. Flood elevations are shown in table 3 and appendix 2 for the 2-, 5-, and 25-year recurrence-interval floods and for the flood of April 2007. Selected cross-section locations used in the hydraulic analyses are shown in the flood profiles in appendixes 1 and 2. Upstream and downstream geographical limits of the study area are indicated on the flood profiles.

The HEC-RAS model calibration of the April 2007 flood to the 22 surveyed high-water marks (table 4) yielded an average elevation difference of $0.30 \mathrm{ft}$ (approximately 3.6 in.) and a standard deviation of 0.81 . A comparison of the HEC-RAS model calibration of the April 2007 flood to the 13 surveyed high-water marks rated as "good" in table 4 yielded an average elevation difference of $0.14 \mathrm{ft}$ (approximately 1.7 in.) and a standard deviation of 0.55 . Discrepancies between model and field results may be due to model assumptions or in the case of field-surveyed high-water marks, a field elevation higher than that modeled may be due to debris in the river, which can cause a higher localized water surface. A field elevation lower than that modeled may be due to an elevation from a mark type (seed, wash, debris, or silt lines) carried to a lower elevation as the flood waters receded.

For the selected locations shown in table 5, the average 100-year recurrence-interval flood elevation was $0.28 \mathrm{ft}$ (approximately 3.3 in.) lower in this 2009 flood study than in the 1978 FISs. Locations for comparison were selected where water-surface-elevation data were determined in both the 1978 FISs and the current study. Selected table 5 BFEs for the 2009 flood study are also shown in table 6 .

The results of the water-surface computations are tabulated for selected cross sections for the Suncook River (table 6) with all increases in the 100-year recurrenceinterval flood elevation limited to a maximum of $1.0 \mathrm{ft}$. For areas between cross sections, the floodway boundaries were interpolated. The computed floodway is shown on the flood map in appendix 4. A listing of stream velocities at selected cross sections is provided in table 6 .

Table 1. Drainage areas and peak recurrence-interval flows for selected locations on the Suncook River in Epsom, Pembroke, and Allenstown, NH.

$\left[\mathrm{mi}^{2}\right.$, square miles; $\mathrm{ft}^{3} / \mathrm{s}$, cubic feet per second]

\begin{tabular}{|c|c|c|c|c|c|c|c|c|c|}
\hline \multirow{2}{*}{ Location } & \multirow{2}{*}{$\begin{array}{c}\text { Drainage } \\
\text { area } \\
\left(\mathrm{mi}^{2}\right)\end{array}$} & \multicolumn{8}{|c|}{$\begin{array}{c}\text { Peak flow } \\
\left(\mathrm{ft}^{3} / \mathrm{s}\right)\end{array}$} \\
\hline & & 2-year & 5-year & 10-year & 25-year & 50-year & 100-year & 500-year & $\begin{array}{l}\text { April } \\
2007\end{array}$ \\
\hline At Suncook River streamgage & 154.4 & 2,230 & 3,550 & 4,680 & 6,430 & 7,990 & 9,820 & 15,300 & 10,600 \\
\hline At U.S. Route 4 in Epsom & 161.2 & 2,320 & 3,700 & 4,870 & 6,690 & 8,330 & 10,200 & 15,900 & 11,000 \\
\hline Below Little Suncook River & 200.9 & 2,850 & 4,550 & 5,990 & 8,230 & 10,240 & 12,600 & 19,600 & 13,600 \\
\hline Above Bear Brook & 219.3 & 3,100 & 4,940 & 6,510 & 8,940 & 11,100 & 13,700 & 21,300 & 14,700 \\
\hline Below Bear Brook & 236.4 & 3,330 & 5,310 & 6,990 & 9,590 & 11,900 & 14,700 & 22,800 & 15,800 \\
\hline At U.S. Route 28 bridge & 240.1 & 3,370 & 5,380 & 7,090 & 9,730 & 12,100 & 14,900 & 23,200 & 16,100 \\
\hline At U.S. Route 3 in Suncook & 255.2 & 3,570 & 5,700 & 7,510 & 10,300 & 12,800 & 15,700 & 24,500 & 17,000 \\
\hline
\end{tabular}




\section{Summary}

Two rainfall events in May 2006 and April 2007 resulted in severe flooding of the Suncook River. More than 8.8 inches of precipitation from May 13 to 16, 2006, resulted in a flood that lead to an avulsion of a streambank and a new reach location for part of the Suncook River. More than 7 inches of precipitation from April 16 to 18, 2007, resulted in another flood. Both floods transported large quantities of gravel, sand, silt, and clay downstream. This 2009 flood study by the U.S. Geological Survey, in cooperation with the Federal Emergency Management Agency, was undertaken to help guide state and local officials in redevelopment and replacement of damaged infrastructure, allocation of state and federal recovery resources, and in ensuring that effective mitigation measures are in place to avoid future flood losses.

Water-surface elevations and profiles are presented in this report that were determined using the U.S. Army Corps of Engineers one-dimensional Hydrologic Engineering Center River Analysis System (HEC-RAS) model for the Suncook River from its confluence with the Merrimack River in the Village of Suncook, NH, to the upstream corporate limit of the town of Epson, $\mathrm{NH}$ (approximately 15.9 miles). Floods of magnitudes that are expected to be equaled or exceeded once on the average during any 10-, 50-, 100-, or 500 -year period (recurrence interval) were modeled using HEC-RAS because these floods are considered important for flood-plain management, determination of flood-insurance rates, and design of structures, such as bridges and culverts. In addition, floods of magnitudes that are expected to be equaled or exceeded once on the average during any 2-, 5-, and 25-year period (recurrence interval) and the April 2007 flood were modeled using HEC-RAS. The analyses in this study reflect the flooding potentials based on conditions in the communities of Epsom, Pembroke, and Allenstown at the time of completion of this study (2009). Changes in the 100-year recurrence interval flood elevation from the 1979 flood study were typically less than 2 feet, with the exception of a location 900 feet upstream from the avulsion which, due to backwater from the dams in the abandoned channel, was 12 feet higher in 1979 than in the present study.

\section{References Cited}

Arcement, G.J., and Schneider, V.R., 1989, Guide for selecting Manning's roughness coefficients for natural channels and flood plains: U.S. Geological Survey Water-Supply Paper $2339,69 \mathrm{p}$.

Barnes, H.H., Jr., 1967, Roughness characteristics of natural channels: U.S. Geological Survey Water-Supply Paper $1849,213 \mathrm{p}$.
Eastern Topographics, 2007, Photogrammetric ground control report for the Town of Epsom, NH, Suncook River area: Epsom, NH R10B/10343\{3\}-1, August 30, 2007, NGVD 29, 1-ft contour interval, scale 1:12,000.

Eastern Topographics, 2008, Photogrammetric ground control report for the Towns of Epsom and Allenstown, NH, Suncook River area: Epsom and Allenstown, $\mathrm{NH}$ R10A/10573, August 30, 2007, NGVD 29, 4-ft contour interval, scale 1:36,000.

Flynn, R.H., 2008, Flood of April 2007 in New Hampshire: U.S. Geological Survey Scientific Investigations Report 2008-5120, 48 p. (Available at http://pubs.usgs.gov/ $\operatorname{sir} / 2008 / 5120 /$.

Leica Geosystems, 2008, Leica GPS1200, GPS1200 Surveying Systems: accessed November 9, 2008, at http://www.leica-geosystems.com/en/Products-LeicaSystem-1200_4580.htm.

Matthai, H.F., 1967, Measurement of peak discharge at width contractions by indirect methods: U.S. Geological Survey Techniques of Water-Resources Investigations, book 3 , chap. A4, 44 p.

Mueller, D.S., and Wagner, C.R., 2009, Measuring discharge with acoustic doppler current profilers from a moving boat: U.S. Geological Survey Techniques and Methods 3-A22, 72 p. (Available at http://pubs.water.usgs.gov/tm3a22.)

National Climate Data Center, 2008, Local climatological data annual summary with comparative data Concord, New Hampshire (KCON): accessed April 22, 2009, at http://www1.ncdc.noaa.gov/pub/orders/FF3E95A7-6803492A-7054-C33BBF06B197.PDF.

New Hampshire Department of Transportation, 2006, 2005 1-ft Color Aerial Imagery-Southeast NH, Imagery acquired at an elevation of approximately 9,800 ft. AMSL on May 11, 2005.

New Hampshire Employment Security, Economic and Labor Market Information Bureau, 2009a, Community profiles (Allenstown, NH): accessed April 22, 2009, at http://www. nh.gov/nhes/elmi/htmlprofiles/pdfs/allenstown.pdf.

New Hampshire Employment Security, Economic and Labor Market Information Bureau, 2009b, Community profiles (Epsom, NH): accessed April 22, 2009, at http://www. nh.gov/nhes/elmi/htmlprofiles/pdfs/epsom.pdf.

New Hampshire Employment Security, Economic and Labor Market Information Bureau, 2009c, Community profiles (Pembroke, NH): accessed April 22, 2009, at http://www. nh.gov/nhes/elmi/htmlprofiles/pdfs/pembroke.pdf.

Olson, S.A., 2007, Flood of May 2006 in New Hampshire: U.S. Geological Survey Open-File Report 2007-1122, 32 p. (Available at http://pubs.water.usgs.gov/ofr2007-1122.) 
U.S. Army Corps of Engineers, 2005, HEC-RAS, version 3.1.3: Hydrologic Engineering Center, accessed September 2, 2007, at http://www.hec.usace.army.mil.

U.S. Army Corps of Engineers, 2008a, Hydrologic Engineering Center-River Analysis System (HEC-RAS): Davis, Calif., v. 4.0.0, March 2008.

U.S. Army Corps of Engineers, 2008b, Hydrologic Engineering Center-River Analysis System (HEC-RAS), HEC-RAS features: accessed March 29, 2009, at http://www.hec. usace.army.mil/software/hec-ras/hecras-features.html.

U.S. Department of Housing and Urban Development Federal Insurance Administration, 1978a, Flood-Insurance Study, Town of Allenstown, Merrimack County, New Hampshire: Washington, D.C., 16 p.

U.S. Department of Housing and Urban Development Federal Insurance Administration, 1978b, Flood-Insurance Study, Town of Epsom, Merrimack County, New Hampshire: Washington, D.C., 19 p.

U.S. Department of Housing and Urban Development Federal Insurance Administration, 1978c, Flood-Insurance Study, Town of Pembroke, Merrimack County, New Hampshire: Washington, D.C., 17 p.

U.S. Geological Survey, 1967a, Photoinspected 1974, Gossville, New Hampshire, 7.5-minute series quadrangle map: U.S. Geological Survey Topographic Map, 10-ft contour interval, scale 1:24,000.
U.S. Geological Survey, 1967b, Photoinspected 1985, Suncook, New Hampshire, 7.5-minute series quadrangle map: U.S. Geological Survey Topographic Map, 10-ft contour interval, scale 1:24,000.

U.S. Geological Survey, 1968, Photorevised 1985, Manchester North, New Hampshire, 7.5-minute series quadrangle map: U.S. Geological Survey Topographic Map, 10-ft contour interval, scale 1:24,000.

U.S. Geological Survey, 1981, Pittsfield, New Hampshire, 7.5-minute series quadrangle map: U.S. Geological Survey Topographic Map, 20-ft contour interval, scale 1:24,000.

U.S. Geological Survey, 2008a, Water resources application software, PeakFQ: accessed October 12, 2008, at http://water.usgs.gov/software/peakfq.html.

U.S. Geological Survey, 2008b, Peak streamflow for New Hampshire: National Water Information System, accessed October 12, 2008, at http://nwis.waterdata.usgs.gov/nh/ nwis/peak.

U.S. Interagency Advisory Committee on Water Data, 1982, Guidelines for determining flood flow frequency, Bulletin 17-B of the Hydrology Subcommittee: Reston, Va., U.S. Geological Survey, Office of Water Data Coordination, $183 \mathrm{p}$.

Wittkop, C., 2006, NH Geological Survey letter to the New Hampshire Department of Environmental Services entitled: Suncook River Initial Assessment, 2 p. 
Table 2. Cross sections and the 10-, 50-, 100-, and 500-year recurrence-interval flood data for Suncook River in Epsom, Pembroke, and Allenstown, $\mathrm{NH}$.

[Location of cross sections A-DW are in appendix 4, where scale permits, and in appendix 1; ft, feet; NGVD 29, National Geodetic Vertical Datum of 1929]

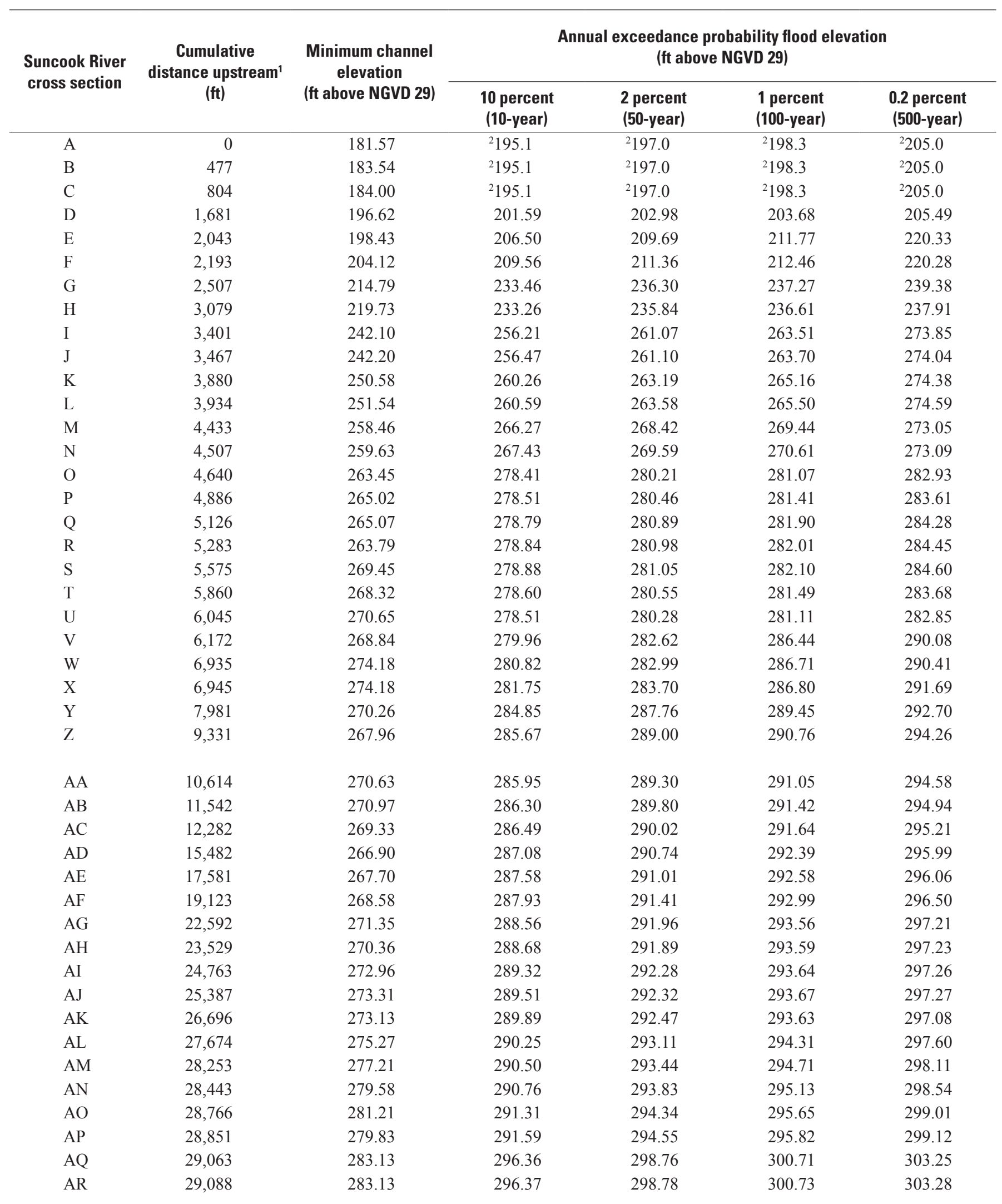


Table 2. Cross sections and the 10-, 50-, 100-, and 500-year recurrence-interval flood data for Suncook River in Epsom, Pembroke, and Allenstown, NH.-Continued

[Location of cross sections A-DW are in appendix 4, where scale permits, and in appendix 1; ft, feet; NGVD 29, National Geodetic Vertical Datum of 1929]

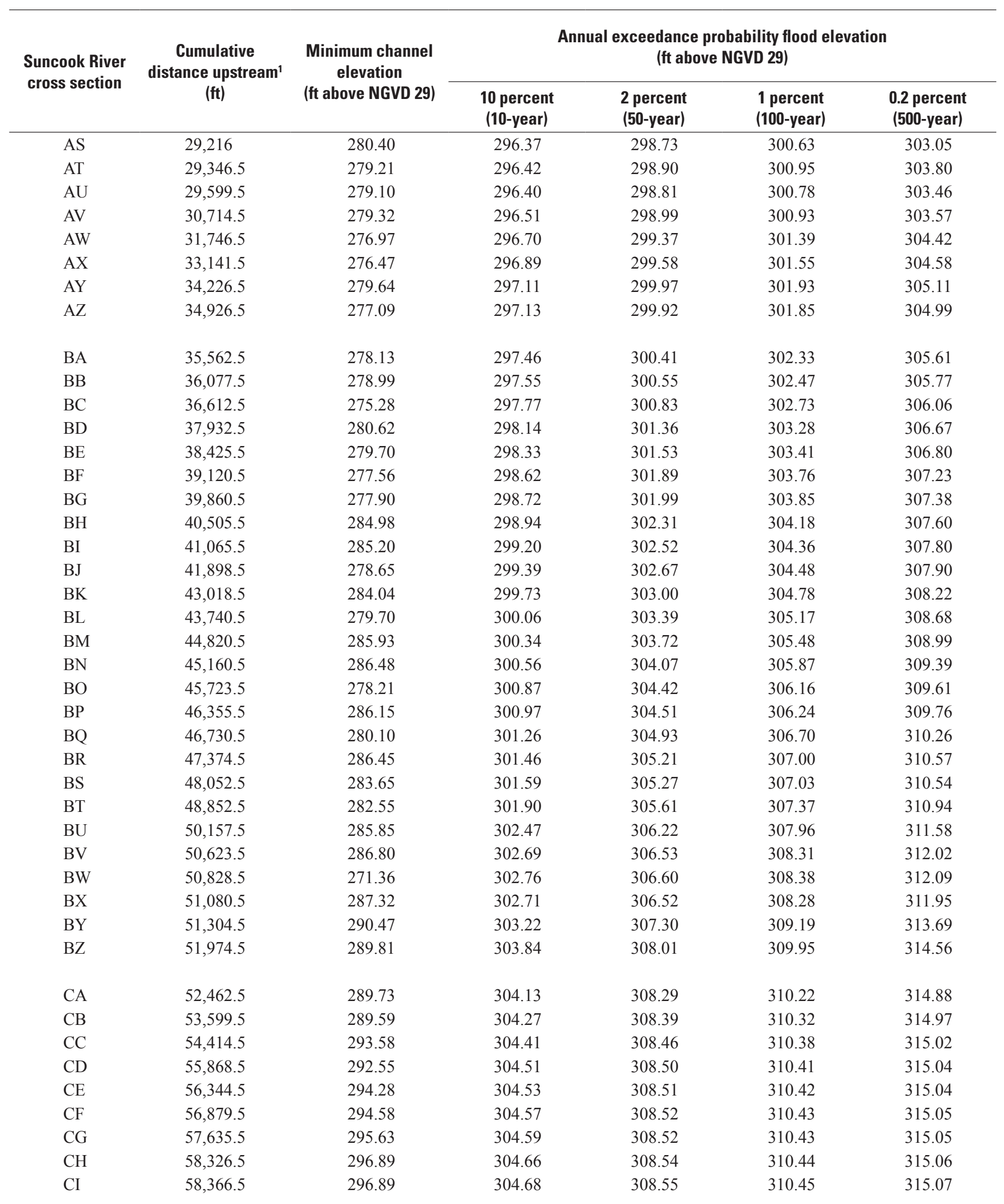


Table 2. Cross sections and the 10-, 50-, 100-, and 500-year recurrence-interval flood data for Suncook River in Epsom, Pembroke, and Allenstown, NH.-Continued

[Location of cross sections A-DW are in appendix 4, where scale permits, and in appendix 1; ft, feet; NGVD 29, National Geodetic Vertical Datum of 1929]

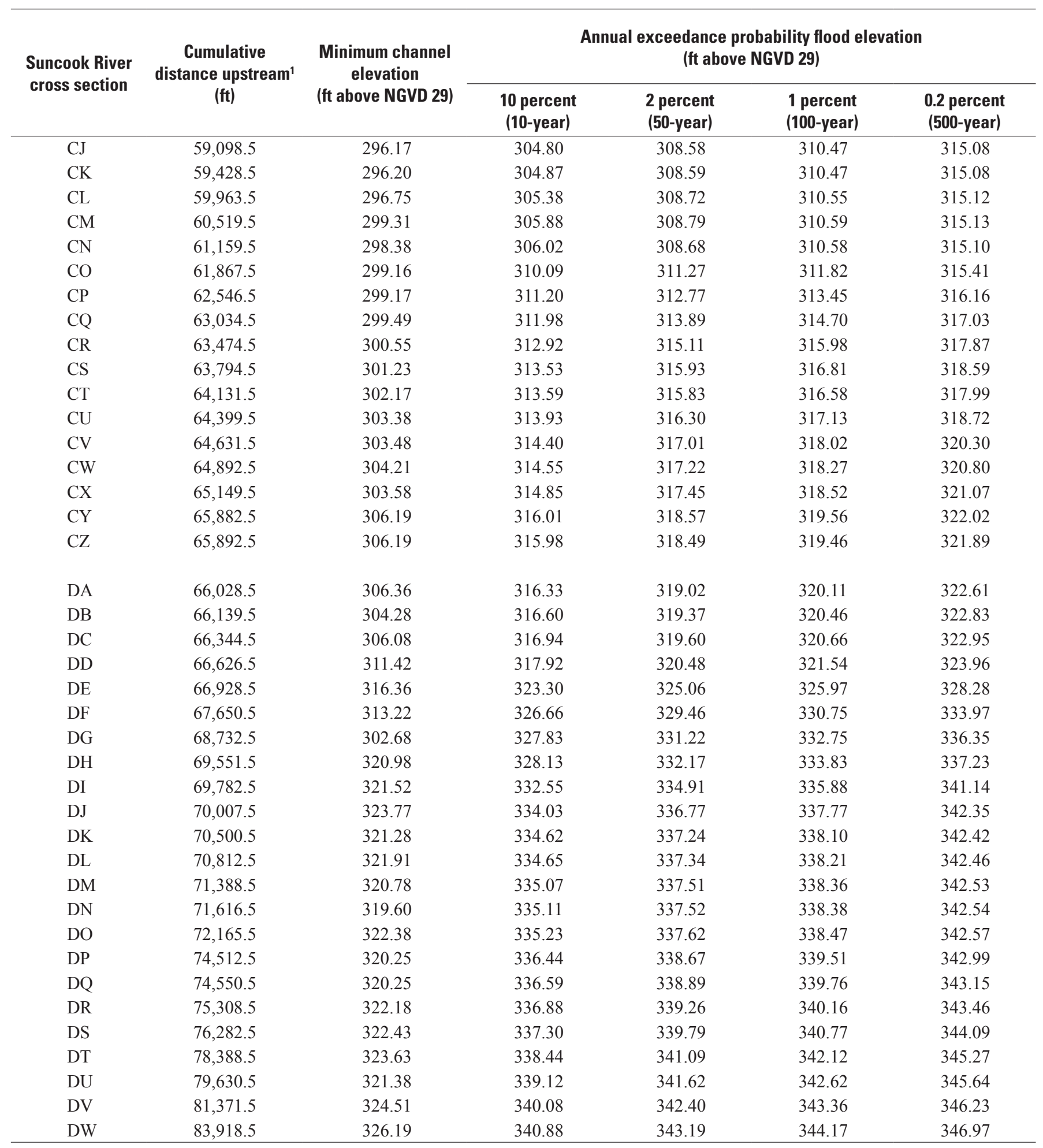

${ }^{1}$ Feet above confluence with Merrimack River.

${ }^{2}$ Backwater from Merrimack River. 
Table 3. Cross sections and the 2-, 5-, 25-year recurrence-interval and April 2007 flood data for Suncook River in Epsom, Pembroke, and Allenstown, NH.

[Location of cross sections A-DW are in appendix 4, where scale permits, and in appendix 1; ft, feet; NGVD 29, National Geodetic Vertical Datum of 1929]

\begin{tabular}{|c|c|c|c|c|c|c|}
\hline \multirow{2}{*}{$\begin{array}{l}\text { Suncook River } \\
\text { cross section }\end{array}$} & \multirow{2}{*}{$\begin{array}{c}\text { Cumulative } \\
\text { distance upstream }{ }^{1} \\
\text { (ft) }\end{array}$} & \multirow{2}{*}{$\begin{array}{l}\text { Channel elevation } \\
\text { (ft above NGVD 29) }\end{array}$} & \multicolumn{4}{|c|}{$\begin{array}{l}\text { Annual exceedance probability flood elevation } \\
\text { (ft above NGVD 29) }\end{array}$} \\
\hline & & & $\begin{array}{l}50 \text { percent } \\
\text { (2-year) }\end{array}$ & $\begin{array}{l}20 \text { percent } \\
\text { (5-year) }\end{array}$ & $\begin{array}{l}4 \text { percent } \\
\text { (25-year) }\end{array}$ & April 2007 \\
\hline A & 0 & 181.57 & 186.44 & 187.25 & 188.76 & 190.04 \\
\hline B & 477 & 183.54 & 188.82 & 189.62 & 190.94 & 192.17 \\
\hline $\mathrm{C}$ & 804 & 184.00 & 189.81 & 190.83 & 192.56 & 194.53 \\
\hline $\mathrm{D}$ & 1,681 & 196.62 & 200.32 & 201.05 & 202.36 & 203.93 \\
\hline $\mathrm{E}$ & 2,043 & 198.43 & 204.23 & 205.56 & 207.80 & 212.63 \\
\hline $\mathrm{F}$ & 2,193 & 204.12 & 207.87 & 208.83 & 210.57 & 213.23 \\
\hline $\mathrm{G}$ & 2,507 & 214.79 & 230.67 & 232.27 & 235.13 & 237.62 \\
\hline $\mathrm{H}$ & 3,079 & 219.73 & 230.61 & 232.13 & 234.80 & 236.87 \\
\hline I & 3,401 & 242.10 & 251.35 & 254.09 & 258.86 & 264.51 \\
\hline $\mathrm{J}$ & 3,467 & 242.20 & 254.09 & 255.68 & 258.60 & 264.77 \\
\hline $\mathrm{K}$ & 3,880 & 250.58 & 257.59 & 259.11 & 261.64 & 266.00 \\
\hline $\mathrm{L}$ & 3,934 & 251.54 & 257.82 & 259.40 & 262.04 & 266.33 \\
\hline M & 4,433 & 258.46 & 264.08 & 265.38 & 267.46 & 269.82 \\
\hline $\mathrm{N}$ & 4,507 & 259.63 & 265.25 & 266.55 & 268.65 & 270.96 \\
\hline $\mathrm{O}$ & 4,640 & 263.45 & 276.66 & 277.68 & 279.40 & 281.41 \\
\hline $\mathrm{P}$ & 4,886 & 265.02 & 276.68 & 277.74 & 279.57 & 281.80 \\
\hline Q & 5,126 & 265.07 & 276.81 & 277.95 & 279.94 & 282.30 \\
\hline $\mathrm{R}$ & 5,283 & 263.79 & 276.83 & 277.99 & 280.02 & 282.42 \\
\hline $\mathrm{S}$ & 5,575 & 269.45 & 276.85 & 278.02 & 280.07 & 282.53 \\
\hline $\mathrm{T}$ & 5,860 & 268.32 & 276.75 & 277.82 & 279.67 & 281.86 \\
\hline $\mathrm{U}$ & 6,045 & 270.65 & 276.77 & 277.78 & 279.49 & 281.44 \\
\hline $\mathrm{V}$ & 6,172 & 268.84 & 277.54 & 278.93 & 281.41 & 286.91 \\
\hline W & 6,935 & 274.18 & 279.14 & 280.08 & 281.82 & 287.19 \\
\hline $\mathrm{X}$ & 6,945 & 274.18 & 279.88 & 280.97 & 282.87 & 287.31 \\
\hline $\mathrm{Y}$ & 7,981 & 270.26 & 281.73 & 283.54 & 286.52 & 289.96 \\
\hline Z & 9,331 & 267.96 & 282.14 & 284.17 & 287.58 & 291.34 \\
\hline AA & 10,614 & 270.63 & 282.30 & 284.40 & 287.88 & 291.63 \\
\hline $\mathrm{AB}$ & 11,542 & 270.97 & 282.46 & 284.67 & 288.31 & 291.99 \\
\hline $\mathrm{AC}$ & 12,282 & 269.33 & 282.57 & 284.83 & 288.52 & 292.22 \\
\hline $\mathrm{AD}$ & 15,482 & 266.90 & 282.96 & 285.36 & 289.20 & 292.98 \\
\hline $\mathrm{AE}$ & 17,581 & 267.70 & 283.32 & 285.87 & 289.56 & 293.14 \\
\hline $\mathrm{AF}$ & 19,123 & 268.58 & 283.52 & 286.17 & 289.95 & 293.56 \\
\hline $\mathrm{AG}$ & 22,592 & 271.35 & 284.00 & 286.75 & 290.67 & 294.15 \\
\hline $\mathrm{AH}$ & 23,529 & 270.36 & 284.37 & 286.96 & 290.75 & 294.18 \\
\hline AI & 24,763 & 272.96 & 284.86 & 287.62 & 291.28 & 294.22 \\
\hline AJ & 25,387 & 273.31 & 285.08 & 287.83 & 291.46 & 294.25 \\
\hline $\mathrm{AK}$ & 26,696 & 273.13 & 285.51 & 288.23 & 291.79 & 294.16 \\
\hline $\mathrm{AL}$ & 27,674 & 275.27 & 285.78 & 288.55 & 292.27 & 294.82 \\
\hline $\mathrm{AM}$ & 28,253 & 277.21 & 286.00 & 288.78 & 292.53 & 295.24 \\
\hline $\mathrm{AN}$ & 28,443 & 279.58 & 286.20 & 289.01 & 292.83 & 295.68 \\
\hline $\mathrm{AO}$ & 28,766 & 281.21 & 287.39 & 289.71 & 293.30 & 296.18 \\
\hline AP & 28,851 & 279.83 & 288.00 & 290.09 & 293.51 & 296.34 \\
\hline AQ & 29,063 & 283.13 & 294.24 & 295.47 & 297.61 & 301.13 \\
\hline AR & 29,088 & 283.13 & 294.24 & 295.47 & 297.62 & 301.15 \\
\hline
\end{tabular}


Table 3. Cross sections and the 2-, 5-, 25-year recurrence-interval and April 2007 flood data for Suncook River in Epsom, Pembroke, and Allenstown, NH.-Continued

[Location of cross sections A-DW are in appendix 4, where scale permits, and in appendix 1; ft, feet; NGVD 29, National Geodetic Vertical Datum of 1929]

\begin{tabular}{|c|c|c|c|c|c|c|}
\hline \multirow{2}{*}{$\begin{array}{l}\text { Suncook River } \\
\text { cross section }\end{array}$} & \multirow{2}{*}{$\begin{array}{l}\text { Cumulative } \\
\text { distance upstream } \\
\text { (ft) }\end{array}$} & \multirow{2}{*}{$\begin{array}{l}\text { Channel elevation } \\
\text { (ft above NGVD 29) }\end{array}$} & \multicolumn{4}{|c|}{$\begin{array}{l}\text { Annual exceedance probability flood elevation } \\
\text { (ft above NGVD 29) }\end{array}$} \\
\hline & & & $\begin{array}{l}50 \text { percent } \\
\text { (2-year) }\end{array}$ & $\begin{array}{l}20 \text { percent } \\
\text { (5-year) }\end{array}$ & $\begin{array}{l}4 \text { percent } \\
\text { (25-year) }\end{array}$ & April 2007 \\
\hline AS & 29,216 & 280.40 & 294.25 & 295.48 & 297.59 & 301.04 \\
\hline AT & $29,346.5$ & 279.21 & 294.27 & 295.52 & 297.69 & 301.42 \\
\hline $\mathrm{AU}$ & $29,599.5$ & 279.10 & 294.27 & 295.51 & 297.64 & 301.22 \\
\hline $\mathrm{AV}$ & $30,714.5$ & 279.32 & 294.31 & 295.58 & 297.80 & 301.36 \\
\hline AW & $31,746.5$ & 276.97 & 294.39 & 295.73 & 298.09 & 301.88 \\
\hline $\mathrm{AX}$ & $33,141.5$ & 276.47 & 294.46 & 295.86 & 298.31 & 302.04 \\
\hline $\mathrm{AY}$ & $34,226.5$ & 279.64 & 294.54 & 296.02 & 298.63 & 302.44 \\
\hline $\mathrm{AZ}$ & $34,926.5$ & 277.09 & 294.58 & 296.06 & 298.61 & 302.36 \\
\hline BA & $35,562.5$ & 278.13 & 294.70 & 296.29 & 299.05 & 302.86 \\
\hline BB & $36,077.5$ & 278.99 & 294.75 & 296.37 & 299.17 & 303.00 \\
\hline $\mathrm{BC}$ & $36,612.5$ & 275.28 & 294.85 & 296.55 & 299.43 & 303.27 \\
\hline $\mathrm{BD}$ & $37,932.5$ & 280.62 & 295.03 & 296.84 & 299.89 & 303.84 \\
\hline $\mathrm{BE}$ & $38,425.5$ & 279.70 & 295.18 & 297.03 & 300.08 & 303.97 \\
\hline $\mathrm{BF}$ & $39,120.5$ & 277.56 & 295.34 & 297.27 & 300.41 & 304.33 \\
\hline BG & $39,860.5$ & 277.90 & 295.41 & 297.37 & 300.52 & 304.42 \\
\hline $\mathrm{BH}$ & $40,505.5$ & 284.98 & 295.53 & 297.54 & 300.80 & 304.76 \\
\hline $\mathrm{BI}$ & $41,065.5$ & 285.20 & 295.79 & 297.82 & 301.03 & 304.95 \\
\hline BJ & $41,898.5$ & 278.65 & 296.01 & 298.04 & 301.20 & 305.06 \\
\hline $\mathrm{BK}$ & $43,018.5$ & 284.04 & 296.28 & 298.36 & 301.54 & 305.36 \\
\hline BL & $43,740.5$ & 279.70 & 296.50 & 298.65 & 301.91 & 305.76 \\
\hline $\mathrm{BM}$ & $44,820.5$ & 285.93 & 296.71 & 298.90 & 302.22 & 306.07 \\
\hline $\mathrm{BN}$ & $45,160.5$ & 286.48 & 296.84 & 299.08 & 302.50 & 306.47 \\
\hline $\mathrm{BO}$ & $45,723.5$ & 278.21 & 297.00 & 299.33 & 302.85 & 306.75 \\
\hline $\mathrm{BP}$ & $46,355.5$ & 286.15 & 297.07 & 299.43 & 302.95 & 306.83 \\
\hline BQ & $46,730.5$ & 280.10 & 297.24 & 299.66 & 303.31 & 307.31 \\
\hline $\mathrm{BR}$ & $47,374.5$ & 286.45 & 297.37 & 299.83 & 303.57 & 307.61 \\
\hline BS & $48,052.5$ & 283.65 & 297.54 & 300.00 & 303.65 & 307.63 \\
\hline BT & $48,852.5$ & 282.55 & 297.77 & 300.28 & 303.98 & 307.97 \\
\hline $\mathrm{BU}$ & $50,157.5$ & 285.85 & 298.22 & 300.81 & 304.59 & 308.57 \\
\hline $\mathrm{BV}$ & $50,623.5$ & 286.80 & 298.37 & 300.99 & 304.86 & 308.94 \\
\hline BW & $50,828.5$ & 271.36 & 298.43 & 301.07 & 304.94 & 309.00 \\
\hline $\mathrm{BX}$ & $51,080.5$ & 287.32 & 298.40 & 301.03 & 304.87 & 308.90 \\
\hline $\mathrm{BY}$ & $51,304.5$ & 290.47 & 298.72 & 301.44 & 305.52 & 309.88 \\
\hline $\mathrm{BZ}$ & $51,974.5$ & 289.81 & 299.39 & 302.06 & 306.19 & 310.66 \\
\hline $\mathrm{CA}$ & $52,462.5$ & 289.73 & 299.64 & 302.34 & 306.47 & 310.94 \\
\hline $\mathrm{CB}$ & $53,599.5$ & 289.59 & 300.01 & 302.52 & 306.58 & 311.04 \\
\hline $\mathrm{CC}$ & $54,414.5$ & 293.58 & 300.59 & 302.80 & 306.67 & 311.09 \\
\hline $\mathrm{CD}$ & $55,868.5$ & 292.55 & 301.51 & 303.00 & 306.72 & 311.12 \\
\hline $\mathrm{CE}$ & $56,344.5$ & 294.28 & 301.59 & 303.04 & 306.73 & 311.13 \\
\hline $\mathrm{CF}$ & $56,879.5$ & 294.58 & 301.88 & 303.15 & 306.75 & 311.14 \\
\hline CG & $57,635.5$ & 295.63 & 301.99 & 303.19 & 306.75 & 311.14 \\
\hline $\mathrm{CH}$ & $58,326.5$ & 296.89 & 302.29 & 303.36 & 306.78 & 311.15 \\
\hline CI & $58,366.5$ & 296.89 & 302.33 & 303.40 & 306.80 & 311.16 \\
\hline
\end{tabular}


Table 3. Cross sections and the 2-, 5-, 25-year recurrence-interval and April 2007 flood data for Suncook River in Epsom, Pembroke, and Allenstown, NH.-Continued

[Location of cross sections A-DW are in appendix 4, where scale permits, and in appendix 1; ft, feet; NGVD 29, National Geodetic Vertical Datum of 1929]

\begin{tabular}{|c|c|c|c|c|c|c|}
\hline \multirow{2}{*}{$\begin{array}{l}\text { Suncook River } \\
\text { cross section }\end{array}$} & \multirow{2}{*}{$\begin{array}{c}\text { Cumulative } \\
\text { distance upstream }{ }^{1} \\
\text { (ft) }\end{array}$} & \multirow{2}{*}{$\begin{array}{l}\text { Channel elevation } \\
\text { (ft above NGVD 29) }\end{array}$} & \multicolumn{4}{|c|}{$\begin{array}{l}\text { Annual exceedance probability flood elevation } \\
\text { (ft above NGVD 29) }\end{array}$} \\
\hline & & & $\begin{array}{c}50 \text { percent } \\
\text { (2-year) }\end{array}$ & $\begin{array}{c}20 \text { percent } \\
\text { (5-year) }\end{array}$ & $\begin{array}{l}4 \text { percent } \\
\text { (25-year) }\end{array}$ & April 2007 \\
\hline CJ & $59,098.5$ & 296.17 & 302.54 & 303.59 & 306.85 & 311.18 \\
\hline CK & $59,428.5$ & 296.20 & 302.75 & 303.73 & 306.86 & 311.17 \\
\hline CL & $59,963.5$ & 296.75 & 303.61 & 304.56 & 307.08 & 311.25 \\
\hline $\mathrm{CM}$ & $60,519.5$ & 299.31 & 304.51 & 305.34 & 307.25 & 311.28 \\
\hline $\mathrm{CN}$ & $61,159.5$ & 298.38 & 305.06 & 305.41 & 307.10 & 311.27 \\
\hline $\mathrm{CO}$ & $61,867.5$ & 299.16 & 307.55 & 309.17 & 311.07 & 312.23 \\
\hline $\mathrm{CP}$ & $62,546.5$ & 299.17 & 308.58 & 310.30 & 312.19 & 313.75 \\
\hline CQ & $63,034.5$ & 299.49 & 309.20 & 311.00 & 313.13 & 315.03 \\
\hline CR & $63,474.5$ & 300.55 & 309.85 & 311.80 & 314.21 & 316.31 \\
\hline $\mathrm{CS}$ & $63,794.5$ & 301.23 & 310.33 & 312.33 & 314.94 & 317.11 \\
\hline $\mathrm{CT}$ & $64,131.5$ & 302.17 & 310.49 & 312.42 & 314.93 & 316.82 \\
\hline $\mathrm{CU}$ & $64,399.5$ & 303.38 & 310.80 & 312.74 & 315.33 & 317.41 \\
\hline $\mathrm{CV}$ & $64,631.5$ & 303.48 & 311.17 & 313.14 & 315.92 & 318.39 \\
\hline $\mathrm{CW}$ & $64,892.5$ & 304.21 & 311.35 & 313.29 & 316.10 & 318.67 \\
\hline $\mathrm{CX}$ & $65,149.5$ & 303.58 & 311.79 & 313.63 & 316.34 & 318.92 \\
\hline $\mathrm{CY}$ & $65,882.5$ & 306.19 & 313.08 & 314.82 & 317.52 & 319.94 \\
\hline $\mathrm{CZ}$ & $65,892.5$ & 306.19 & 313.07 & 314.79 & 317.46 & 319.83 \\
\hline DA & $66,028.5$ & 306.36 & 313.36 & 315.11 & 317.90 & 320.53 \\
\hline DB & $66,139.5$ & 304.28 & 313.53 & 315.34 & 318.21 & 320.86 \\
\hline $\mathrm{DC}$ & $66,344.5$ & 306.08 & 314.01 & 315.75 & 318.49 & 321.05 \\
\hline DD & $66,626.5$ & 311.42 & 315.35 & 316.79 & 319.39 & 321.94 \\
\hline $\mathrm{DE}$ & $66,928.5$ & 316.36 & 321.76 & 322.68 & 324.24 & 326.33 \\
\hline DF & $67,650.5$ & 313.22 & 323.80 & 325.48 & 328.23 & 331.26 \\
\hline DG & $68,732.5$ & 302.68 & 324.42 & 326.43 & 329.73 & 333.34 \\
\hline $\mathrm{DH}$ & $69,551.5$ & 320.98 & 326.12 & 327.17 & 330.49 & 334.46 \\
\hline DI & $69,782.5$ & 321.52 & 329.82 & 331.38 & 333.99 & 336.26 \\
\hline DJ & $70,007.5$ & 323.77 & 330.89 & 332.79 & 335.54 & 338.20 \\
\hline DK & $70,500.5$ & 321.28 & 331.34 & 333.31 & 336.19 & 338.48 \\
\hline DL & $70,812.5$ & 321.91 & 331.33 & 333.26 & 336.28 & 338.58 \\
\hline DM & $71,388.5$ & 320.78 & 331.88 & 333.87 & 336.49 & 338.73 \\
\hline DN & $71,616.5$ & 319.60 & 331.98 & 333.94 & 336.52 & 338.75 \\
\hline DO & $72,165.5$ & 322.38 & 332.14 & 334.07 & 336.63 & 338.83 \\
\hline DP & $74,512.5$ & 320.25 & 333.08 & 335.23 & 337.74 & 339.86 \\
\hline DQ & $74,550.5$ & 320.25 & 333.16 & 335.35 & 337.94 & 340.12 \\
\hline DR & $75,308.5$ & 322.18 & 333.40 & 335.60 & 338.28 & 340.52 \\
\hline DS & $76,282.5$ & 322.43 & 333.78 & 336.00 & 338.75 & 341.16 \\
\hline DT & $78,388.5$ & 323.63 & 334.77 & 337.07 & 340.00 & 342.53 \\
\hline DU & $79,630.5$ & 321.38 & 335.51 & 337.81 & 340.61 & 343.01 \\
\hline DV & $81,371.5$ & 324.51 & 336.47 & 338.83 & 341.45 & 343.75 \\
\hline DW & $83,918.5$ & 326.19 & 337.39 & 339.67 & 342.22 & 344.56 \\
\hline
\end{tabular}

\footnotetext{
${ }^{1}$ Feet above confluence with Merrimack River.
} 
Table 4. Surveyed and HEC-RAS-modeled April 2007 elevations of flood high-water marks for the Suncook River, NH.

[HWM, high-water mark; ft, feet; NGVD 29, National Geodetic Vertical Datum of 1929; US, upstream; DS, downstream]

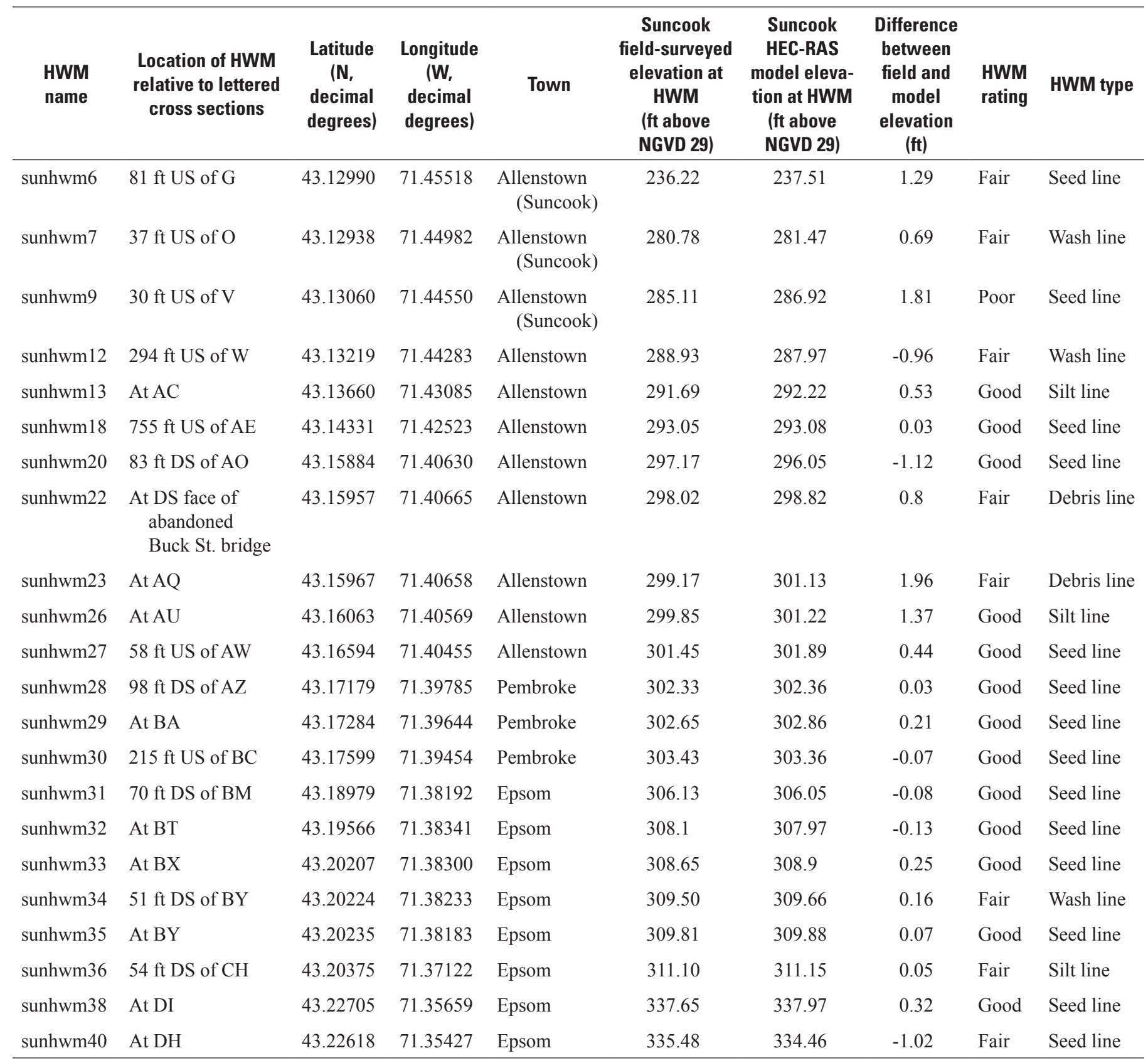


Table 5. $1978 \mathrm{FIS}$ and 2009 flood study 100-year flood elevations for selected locations in the Suncook River in Epsom, Pembroke, and Allenstown, NH.

[FIS, Flood Insurance Study; BFE, base flood elevation (100-year recurrence-interval flood); ft, feet; NGVD 29, National Geodetic Vertical Datum of 1929; US, upstream; DS, downstream; XS, cross section]

\begin{tabular}{|c|c|c|c|}
\hline $\begin{array}{l}\text { Location on } \\
\text { flood-study base map }\end{array}$ & $\begin{array}{c}1978 \text { FIS BFE } \\
\text { elevation } \\
\text { (ft above NGVD 29) }\end{array}$ & $\begin{array}{c}\text { Flood study BFE } \\
\text { elevation } \\
\text { (ft above NGVD 29) }\end{array}$ & $\begin{array}{l}\text { Difference between } 1978 \text { FIS } \\
\text { and flood-study elevation } \\
(\mathrm{ft} \text { above NGVD 29) }\end{array}$ \\
\hline XS E & 206 & 211.8 & 5.8 \\
\hline BFE 215 & 214 & 215 & 1 \\
\hline XS G & 238 & 237.3 & -0.7 \\
\hline US face of Main Street bridge & 262 & 260 & -2 \\
\hline BFE 270 & 269 & 270 & 1 \\
\hline $55 \mathrm{ft}$ US of XS O & 284 & 281.2 & -2.8 \\
\hline $21 \mathrm{ft} \mathrm{DS}$ of BFE 285 & 284 & 285 & 1 \\
\hline XS V & 286 & 286.4 & 0.4 \\
\hline $320 \mathrm{ft}$ US of BFE 290 & 289 & 290 & 1 \\
\hline $320 \mathrm{ft} \mathrm{US}$ of XS AA & 290 & 291.2 & 1.2 \\
\hline $950 \mathrm{ft} \mathrm{US}$ of XS AD & 291 & 292.4 & 1.4 \\
\hline XS AG & 293 & 293.6 & 0.6 \\
\hline XS AK & 294 & 293.6 & -0.4 \\
\hline BFE 295 & 295 & 295 & 0 \\
\hline BFE 300 & 300 & 300 & 0 \\
\hline XS AT & 305 & 301 & -4 \\
\hline XS AX & 306 & 301.6 & -4.4 \\
\hline BFE 306 & 307 & 306 & -1 \\
\hline BFE 307 & 307 & 307 & 0 \\
\hline XS BW & 307 & 308.4 & 1.4 \\
\hline XS BX & 308 & 308.3 & 0.3 \\
\hline US face of Short Falls Road bridge & 309 & 308.5 & -0.5 \\
\hline $170 \mathrm{ft}$ DS XS BZ & 310 & 310 & 0 \\
\hline $231 \mathrm{ft}$ DS XS CM & 311 & 310.5 & -0.5 \\
\hline BFE 313 & 312 & 313 & 1 \\
\hline $370 \mathrm{ft}$ DS XS DH & 339 & 334 & -5 \\
\hline BFE 338 & 339 & 338 & -1 \\
\hline BFE 339 & 340 & 339 & -1 \\
\hline BFE 340 & 341 & 340 & -1 \\
\hline $600 \mathrm{ft} \mathrm{US}$ of XS DS & 342 & 341.2 & -0.8 \\
\hline XS DV & 343 & 343.4 & 0.4 \\
\hline
\end{tabular}

${ }^{1}$ A positive number means that the stream BFE is higher in this study than in the 1978 FIS, and a negative number means that the stream BFE is lower in this study than in the 1978 FIS. 
Table 6. Cross sections, 100-year recurrence-interval, and floodway data for Suncook River in Epsom, Pembroke, and Allenstown, NH.

[ft, feet; ft², square feet; ft/s, feet per second; NGVD 29, National Geodetic Vertical Datum of 1929]

\begin{tabular}{|c|c|c|c|c|c|c|c|c|}
\hline \multicolumn{2}{|c|}{ Flooding source } & \multicolumn{3}{|c|}{ Floodway } & \multicolumn{4}{|c|}{ Base flood water-surface elevation } \\
\hline Cross section & $\begin{array}{l}\text { Cumulative } \\
\text { distance } \\
\text { upstream }{ }^{1} \\
\text { (ft) }\end{array}$ & $\begin{array}{l}\text { Width } \\
\text { (ft) }\end{array}$ & $\begin{array}{c}\text { Section area } \\
\left(\mathrm{ft}^{2}\right)\end{array}$ & $\begin{array}{c}\text { Mean velocity } \\
(\mathrm{ft} / \mathrm{s})\end{array}$ & $\begin{array}{c}\text { Regulatory } \\
\text { (ft above } \\
\text { NGVD 29) }\end{array}$ & $\begin{array}{l}\text { Without } \\
\text { floodway } \\
\text { (ft above } \\
\text { NGVD 29) }\end{array}$ & $\begin{array}{c}\text { With } \\
\text { floodway } \\
\text { (ft above } \\
\text { NGVD 29) }\end{array}$ & $\begin{array}{c}\text { Increase } \\
\text { (ft) }\end{array}$ \\
\hline A & 0 & 387.5 & $1,707.0$ & 9.2 & ${ }^{2} 198.3$ & 189.82 & 189.87 & 0.05 \\
\hline B & 477 & 270.8 & $1,385.1$ & 11.4 & ${ }^{2} 198.3$ & 191.97 & 191.97 & 0 \\
\hline $\mathrm{C}$ & 804 & 322.9 & $2,507.8$ & 6.3 & ${ }^{2} 198.3$ & 194.19 & 194.19 & 0 \\
\hline $\mathrm{D}$ & 1,681 & 231.2 & $1,211.5$ & 13.0 & 203.68 & 203.68 & 203.68 & 0 \\
\hline $\mathrm{E}$ & 2,043 & 141.0 & $1,295.2$ & 12.2 & 211.77 & 211.77 & 211.77 & 0 \\
\hline $\mathrm{F}$ & 2,193 & 174.0 & $1,138.7$ & 13.8 & 212.46 & 212.46 & 212.47 & 0.01 \\
\hline G & 2,507 & 149.0 & $3,006.3$ & 5.2 & 237.27 & 237.27 & 237.59 & 0.32 \\
\hline $\mathrm{H}$ & 3,079 & 84.2 & $1,371.8$ & 11.5 & 236.61 & 236.61 & 237.09 & 0.48 \\
\hline I & 3,401 & 79.0 & $1,456.0$ & 10.8 & 263.51 & 263.51 & 263.7 & 0.2 \\
\hline $\mathrm{J}$ & 3,467 & 148.0 & $1,878.2$ & 8.4 & 263.7 & 263.7 & 264.7 & 1.0 \\
\hline $\mathrm{K}$ & 3,880 & 236.0 & $2,395.8$ & 6.6 & 265.16 & 265.16 & 266.02 & 0.86 \\
\hline $\mathrm{L}$ & 3,934 & 214.0 & $2,200.1$ & 7.2 & 265.5 & 265.5 & 266.29 & 0.8 \\
\hline M & 4,433 & 153.4 & $1,056.8$ & 14.9 & 269.44 & 269.44 & 269.43 & 0 \\
\hline $\mathrm{N}$ & 4,507 & 153.5 & $1,058.6$ & 14.9 & 270.61 & 270.61 & 270.62 & 0 \\
\hline $\mathrm{O}$ & 4,640 & 212.2 & $2,367.9$ & 6.7 & 281.07 & 281.07 & 281.07 & 0 \\
\hline $\mathrm{P}$ & 4,886 & 320.4 & $2,632.2$ & 6.0 & 281.41 & 281.41 & 281.42 & 0.01 \\
\hline Q & 5,126 & 380.8 & $4,350.7$ & 3.6 & 281.9 & 281.9 & 281.9 & 0 \\
\hline $\mathrm{R}$ & 5,283 & 451.0 & $5,645.4$ & 2.8 & 282.01 & 282.01 & 282.01 & 0 \\
\hline $\mathrm{S}$ & 5,575 & 920.0 & $7,809.2$ & 2.0 & 282.1 & 282.1 & 282.1 & 0 \\
\hline $\mathrm{T}$ & 5,860 & 241.0 & $1,930.3$ & 8.2 & 281.49 & 281.49 & 281.49 & 0 \\
\hline $\mathrm{U}$ & 6,045 & 187.5 & $1,307.8$ & 12.0 & 281.11 & 281.11 & 281.12 & 0.01 \\
\hline V & 6,172 & 149.0 & $2,321.1$ & 6.4 & 286.44 & 286.44 & 286.49 & 0.05 \\
\hline W & 6,935 & 149.0 & $1,492.9$ & 10.0 & 286.71 & 286.71 & 286.80 & 0.09 \\
\hline $\mathrm{X}$ & 6,945 & 149.0 & $1,505.7$ & 9.9 & 286.8 & 286.8 & 286.89 & 0.09 \\
\hline $\mathrm{Y}$ & 7,981 & 124.0 & $1,867.7$ & 8.0 & 289.45 & 289.45 & 289.78 & 0.34 \\
\hline Z & 9,331 & 181.4 & $2,798.5$ & 5.3 & 290.76 & 290.76 & 291.15 & 0.39 \\
\hline $\mathrm{AA}$ & 10,614 & 139.0 & $2,523.9$ & 5.9 & 291.05 & 291.05 & 291.52 & 0.47 \\
\hline $\mathrm{AB}$ & 11,542 & 186.0 & $3,107.5$ & 4.8 & 291.42 & 291.42 & 292.12 & 0.70 \\
\hline $\mathrm{AC}$ & 12,282 & 165.0 & $2,984.6$ & 5.0 & 291.64 & 291.64 & 292.36 & 0.71 \\
\hline $\mathrm{AD}$ & 15,482 & 933.0 & $9,180.9$ & 1.6 & 292.39 & 292.39 & 293.18 & 0.79 \\
\hline $\mathrm{AE}$ & 17,581 & 212.1 & $3,278.0$ & 4.5 & 292.58 & 292.58 & 293.46 & 0.89 \\
\hline $\mathrm{AF}$ & 19,123 & 155.0 & $3,042.2$ & 4.9 & 292.99 & 292.99 & 293.93 & 0.94 \\
\hline $\mathrm{AG}$ & 22,592 & $1,518.2$ & $15,498.9$ & 1.0 & 293.56 & 293.56 & 294.51 & 0.94 \\
\hline $\mathrm{AH}$ & 23,529 & $1,536.6$ & $13,447.5$ & 1.1 & 293.59 & 293.59 & 294.53 & 0.94 \\
\hline $\mathrm{AI}$ & 24,763 & $1,878.9$ & $12,068.3$ & 1.2 & 293.64 & 293.64 & 294.58 & 0.94 \\
\hline $\mathrm{AJ}$ & 25,387 & $1,916.4$ & $9,708.4$ & 1.5 & 293.67 & 293.67 & 294.61 & 0.94 \\
\hline AK & 26,696 & 144.7 & $2,403.1$ & 6.2 & 293.63 & 293.63 & 294.57 & 0.94 \\
\hline
\end{tabular}


Table 6. Cross sections, 100-year recurrence-interval, and floodway data for Suncook River in Epsom, Pembroke, and Allenstown, NH.-Continued

[ft, feet; $\mathrm{ft}^{2}$, square feet; ft/s, feet per second; NGVD 29, National Geodetic Vertical Datum of 1929]

\begin{tabular}{|c|c|c|c|c|c|c|c|c|}
\hline \multicolumn{2}{|c|}{ Flooding source } & \multicolumn{3}{|c|}{ Floodway } & \multicolumn{4}{|c|}{ Base flood water-surface elevation } \\
\hline Cross section & $\begin{array}{l}\text { Cumulative } \\
\text { distance } \\
\text { upstream } \\
\text { (ft) }\end{array}$ & $\begin{array}{l}\text { Width } \\
\text { (ft) }\end{array}$ & $\begin{array}{c}\text { Section area } \\
\left(\mathrm{ft}^{2}\right)\end{array}$ & $\begin{array}{c}\text { Mean velocity } \\
(\mathrm{ft} / \mathrm{s})\end{array}$ & $\begin{array}{c}\text { Regulatory } \\
\text { (ft above } \\
\text { NGVD 29) }\end{array}$ & $\begin{array}{l}\text { Without } \\
\text { floodway } \\
\text { (ft above } \\
\text { NGVD 29) }\end{array}$ & $\begin{array}{c}\text { With } \\
\text { floodway } \\
\text { (ft above } \\
\text { NGVD 29) }\end{array}$ & $\begin{array}{c}\text { Increase } \\
\text { (ft) }\end{array}$ \\
\hline $\mathrm{AL}$ & 27,674 & 148.7 & $2,459.8$ & 6.1 & 294.31 & 294.31 & 295.2 & 0.88 \\
\hline $\mathrm{AM}$ & 28,253 & 188.0 & $2,683.1$ & 5.5 & 294.71 & 294.71 & 295.64 & 0.93 \\
\hline $\mathrm{AN}$ & 28,443 & 294.8 & $3,969.5$ & 3.8 & 295.13 & 295.13 & 296.07 & 0.94 \\
\hline $\mathrm{AO}$ & 28,766 & 354.6 & $3,307.1$ & 4.5 & 295.65 & 295.65 & 296.56 & 0.91 \\
\hline AP & 28,851 & 272.4 & $2,730.1$ & 5.5 & 295.82 & 295.82 & 296.68 & 0.86 \\
\hline AQ & 29,063 & 317.6 & $3,132.9$ & 4.8 & 300.71 & 300.71 & 300.74 & 0.03 \\
\hline AR & 29,088 & 333.6 & $3,325.5$ & 4.5 & 300.73 & 300.73 & 300.75 & 0.02 \\
\hline AS & 29,216 & 207.3 & $2,735.1$ & 5.4 & 300.63 & 300.63 & 300.66 & 0.03 \\
\hline AT & $29,346.5$ & 208.0 & $2,730.1$ & 5.4 & 300.95 & 300.95 & 300.96 & 0.01 \\
\hline $\mathrm{AU}$ & $29,599.5$ & 119.8 & $2,106.0$ & 7.0 & 300.78 & 300.78 & 300.81 & 0.03 \\
\hline AV & $30,714.5$ & 103.1 & $1,857.6$ & 7.9 & 300.92 & 300.92 & 300.97 & 0.05 \\
\hline AW & $31,746.5$ & 110.9 & $2,126.1$ & 6.9 & 301.39 & 301.39 & 301.49 & 0.10 \\
\hline $\mathrm{AX}$ & $33,141.5$ & 137.2 & $2,468.1$ & 5.9 & 301.54 & 301.54 & 301.96 & 0.42 \\
\hline AY & $34,226.5$ & 148.0 & $2,633.6$ & 5.6 & 301.93 & 301.93 & 302.28 & 0.35 \\
\hline $\mathrm{AZ}$ & $34,926.5$ & 98.0 & $1,941.5$ & 7.6 & 301.85 & 301.85 & 302.31 & 0.46 \\
\hline $\mathrm{BA}$ & $35,562.5$ & 147.6 & $2,753.6$ & 5.0 & 302.33 & 302.33 & 303.09 & 0.76 \\
\hline $\mathrm{BB}$ & $36,077.5$ & 133.0 & $2,403.1$ & 5.5 & 302.47 & 302.47 & 303.22 & 0.75 \\
\hline $\mathrm{BC}$ & $36,612.5$ & 161.0 & $2,985.4$ & 4.4 & 302.73 & 302.73 & 303.62 & 0.89 \\
\hline $\mathrm{BD}$ & $37,932.5$ & 269.5 & $3,472.3$ & 3.8 & 303.27 & 303.27 & 304.09 & 0.82 \\
\hline $\mathrm{BE}$ & $38,425.5$ & 264.8 & $3,516.5$ & 3.7 & 303.41 & 303.41 & 304.31 & 0.90 \\
\hline $\mathrm{BF}$ & $39,120.5$ & 308.7 & $4,529.2$ & 2.9 & 303.76 & 303.76 & 304.70 & 0.94 \\
\hline BG & $39,860.5$ & 516.5 & $5,213.7$ & 2.5 & 303.84 & 303.84 & 304.84 & 1.00 \\
\hline $\mathrm{BH}$ & $40,505.5$ & 502.5 & $6,360.6$ & 2.4 & 304.17 & 304.17 & 305.07 & 0.90 \\
\hline BI & $41,065.5$ & 543.9 & $6,693.7$ & 2.1 & 304.36 & 304.36 & 305.28 & 0.92 \\
\hline BJ & $41,898.5$ & 413.1 & $5,144.0$ & 2.6 & 304.48 & 304.48 & 305.47 & 0.99 \\
\hline BK & $43,018.5$ & 309.6 & $4,301.7$ & 3.3 & 304.77 & 304.77 & 305.77 & 1.00 \\
\hline $\mathrm{BL}$ & $43,740.5$ & 260.5 & $4,250.1$ & 3.1 & 305.16 & 305.16 & 306.14 & 0.98 \\
\hline $\mathrm{BM}$ & $44,820.5$ & 159.6 & $2,586.4$ & 5.1 & 305.48 & 305.48 & 306.46 & 0.98 \\
\hline $\mathrm{BN}$ & $45,160.5$ & 228.7 & $3,015.4$ & 4.3 & 305.87 & 305.87 & 306.81 & 0.94 \\
\hline $\mathrm{BO}$ & $45,723.5$ & 184.4 & $3,463.7$ & 3.8 & 306.16 & 306.16 & 307.11 & 0.95 \\
\hline BP & $46,355.5$ & 140.1 & $2,426.9$ & 5.4 & 306.23 & 306.23 & 307.19 & 0.96 \\
\hline BQ & $46,730.5$ & 212.2 & $3,490.0$ & 3.8 & 306.70 & 306.70 & 307.61 & 0.91 \\
\hline $\mathrm{BR}$ & $47,374.5$ & 402.3 & $4,727.3$ & 2.8 & 306.99 & 306.99 & 307.85 & 0.86 \\
\hline $\mathrm{BS}$ & $48,052.5$ & 189.6 & $3,168.9$ & 4.1 & 307.02 & 307.02 & 308.00 & 0.98 \\
\hline BT & $48,852.5$ & 239.1 & $3,468.5$ & 3.8 & 307.36 & 307.36 & 308.34 & 0.98 \\
\hline BU & $50,157.5$ & 240.8 & $3,255.5$ & 4.0 & 307.95 & 307.95 & 308.86 & 0.91 \\
\hline BV & $50,623.5$ & 297.7 & $4,622.5$ & 2.8 & 308.30 & 308.30 & 309.11 & 0.81 \\
\hline
\end{tabular}


Table 6. Cross sections, 100-year recurrence-interval, and floodway data for Suncook River in Epsom, Pembroke, and Allenstown, NH.-Continued

[ft, feet; ft², square feet; ft/s, feet per second; NGVD 29, National Geodetic Vertical Datum of 1929]

\begin{tabular}{|c|c|c|c|c|c|c|c|c|}
\hline \multicolumn{2}{|c|}{ Flooding source } & \multicolumn{3}{|c|}{ Floodway } & \multicolumn{4}{|c|}{ Base flood water-surface elevation } \\
\hline Cross section & $\begin{array}{l}\text { Cumulative } \\
\text { distance } \\
\text { upstream }{ }^{1} \\
\text { (ft) }\end{array}$ & $\begin{array}{l}\text { Width } \\
\text { (ft) }\end{array}$ & $\begin{array}{c}\text { Section area } \\
\left(\mathrm{ft}^{2}\right)\end{array}$ & $\begin{array}{l}\text { Mean velocity } \\
\text { (ft/s) }\end{array}$ & $\begin{array}{c}\text { Regulatory } \\
\text { (ft above } \\
\text { NGVD 29) }\end{array}$ & $\begin{array}{l}\text { Without } \\
\text { floodway } \\
\text { (ft above } \\
\text { NGVD 29) }\end{array}$ & $\begin{array}{c}\text { With } \\
\text { floodway } \\
\text { (ft above } \\
\text { NGVD 29) }\end{array}$ & $\begin{array}{c}\text { Increase } \\
(\mathrm{ft})\end{array}$ \\
\hline BW & $50,828.5$ & 302.7 & $8,158.7$ & 1.6 & 308.37 & 308.37 & 309.26 & 0.89 \\
\hline $\mathrm{BX}$ & $51,080.5$ & 194.9 & $3,660.3$ & 3.6 & 308.27 & 308.27 & 309.15 & 0.88 \\
\hline BY & $51,304.5$ & 156.6 & $2,020.0$ & 6.2 & 309.19 & 309.19 & 309.95 & 0.76 \\
\hline $\mathrm{BZ}$ & $51,974.5$ & 243.3 & $3,484.7$ & 3.6 & 309.94 & 309.94 & 310.52 & 0.58 \\
\hline $\mathrm{CA}$ & $52,462.5$ & 456.7 & $6,733.7$ & 1.9 & 310.22 & 310.22 & 310.88 & 0.66 \\
\hline $\mathrm{CB}$ & $53,599.5$ & 509.7 & $6,345.9$ & 2.0 & 310.32 & 310.32 & 311.05 & 0.73 \\
\hline $\mathrm{CC}$ & $54,414.5$ & 564.0 & $6,552.2$ & 1.9 & 310.38 & 310.38 & 311.28 & 0.89 \\
\hline $\mathrm{CD}$ & $55,868.5$ & $2,183.0$ & $24,461.2$ & 0.5 & 310.40 & 310.40 & 311.40 & 1.00 \\
\hline $\mathrm{CE}$ & $56,344.5$ & $2,197.9$ & $23,020.7$ & 0.6 & 310.41 & 310.41 & 311.41 & 1.00 \\
\hline $\mathrm{CF}$ & $56,879.5$ & $2,699.9$ & $28,973.8$ & 0.4 & 310.42 & 310.42 & 311.42 & 1.00 \\
\hline $\mathrm{CG}$ & $57,635.5$ & $1,589.8$ & $16,522.3$ & 0.8 & 310.42 & 310.42 & 311.42 & 1.00 \\
\hline $\mathrm{CH}$ & $58,326.5$ & $1,291.8$ & $14,011.0$ & 0.9 & 310.44 & 310.44 & 311.44 & 1.00 \\
\hline $\mathrm{CI}$ & $58,366.5$ & $1,303.9$ & $13,805.1$ & 0.9 & 310.44 & 310.44 & 311.44 & 1.00 \\
\hline CJ & $59,098.5$ & $1,466.9$ & $14,105.0$ & 0.9 & 310.47 & 310.47 & 311.47 & 1.00 \\
\hline CK & $59,428.5$ & 818.6 & $7,457.9$ & 1.7 & 310.46 & 310.46 & 311.46 & 1.00 \\
\hline CL & $59,963.5$ & $1,005.8$ & $7,939.2$ & 1.6 & 310.55 & 310.55 & 311.55 & 1.00 \\
\hline $\mathrm{CM}$ & $60,519.5$ & 914.4 & $6,572.4$ & 1.9 & 310.58 & 310.58 & 311.58 & 1.00 \\
\hline $\mathrm{CN}$ & $61,159.5$ & 381.0 & $2,500.6$ & 5.0 & 310.57 & 310.57 & 311.48 & 0.91 \\
\hline $\mathrm{CO}$ & $61,867.5$ & 345.5 & $2,096.5$ & 6.0 & 311.82 & 311.82 & 312.82 & 1.00 \\
\hline $\mathrm{CP}$ & $62,546.5$ & 240.0 & $1,786.0$ & 7.0 & 313.45 & 313.45 & 314.25 & 0.80 \\
\hline CQ & $63,034.5$ & 240.5 & $1,888.5$ & 6.7 & 314.7 & 314.7 & 315.48 & 0.78 \\
\hline $\mathrm{CR}$ & $63,474.5$ & 251.1 & $2,187.9$ & 5.8 & 315.98 & 315.98 & 316.82 & 0.83 \\
\hline $\mathrm{CS}$ & $63,794.5$ & 463.0 & $3,941.7$ & 3.2 & 316.81 & 316.81 & 317.79 & 0.98 \\
\hline $\mathrm{CT}$ & $64,131.5$ & 154.0 & $1,726.3$ & 7.3 & 316.58 & 316.58 & 317.58 & 1.00 \\
\hline $\mathrm{CU}$ & $64,399.5$ & 144.4 & $1,671.7$ & 7.5 & 317.13 & 317.13 & 317.99 & 0.86 \\
\hline $\mathrm{CV}$ & $64,631.5$ & 123.0 & $1,499.2$ & 8.4 & 318.02 & 318.02 & 318.24 & 0.22 \\
\hline $\mathrm{CW}$ & $64,892.5$ & 176.3 & $2,036.7$ & 6.2 & 318.27 & 318.27 & 319.21 & 0.94 \\
\hline $\mathrm{CX}$ & $65,149.5$ & 183.6 & $1,963.3$ & 6.4 & 318.52 & 318.52 & 319.51 & 0.99 \\
\hline $\mathrm{CY}$ & $65,882.5$ & 162.8 & $1,826.6$ & 6.9 & 319.56 & 319.56 & 320.48 & 0.92 \\
\hline $\mathrm{CZ}$ & $65,892.5$ & 143.4 & $1,656.2$ & 7.6 & 319.46 & 319.46 & 320.38 & 0.92 \\
\hline $\mathrm{DA}$ & $66,028.5$ & 149.0 & $1,883.5$ & 6.7 & 320.11 & 320.11 & 320.81 & 0.70 \\
\hline DB & $66,139.5$ & 230.8 & $2,528.4$ & 5.0 & 320.46 & 320.46 & 321.29 & 0.83 \\
\hline $\mathrm{DC}$ & $66,344.5$ & 156.2 & $1,856.2$ & 6.8 & 320.66 & 320.66 & 321.44 & 0.78 \\
\hline $\mathrm{DD}$ & $66,626.5$ & 138.6 & $1,181.1$ & 10.7 & 321.54 & 321.54 & 322.21 & 0.67 \\
\hline $\mathrm{DE}$ & $66,928.5$ & 133.0 & $1,034.3$ & 12.2 & 325.97 & 325.97 & 325.97 & 0 \\
\hline DF & $67,650.5$ & 141.6 & $1,990.9$ & 6.3 & 330.75 & 330.75 & 331.16 & 0.41 \\
\hline DG & $68,732.5$ & 119.7 & $1,972.9$ & 5.2 & 332.75 & 332.75 & 333.02 & 0.27 \\
\hline
\end{tabular}


Table 6. Cross sections, 100-year recurrence-interval, and floodway data for Suncook River in Epsom, Pembroke, and Allenstown, NH.-Continued

[ft, feet; ft², square feet; ft/s, feet per second; NGVD 29, National Geodetic Vertical Datum of 1929]

\begin{tabular}{|c|c|c|c|c|c|c|c|c|}
\hline \multicolumn{2}{|c|}{ Flooding source } & \multicolumn{3}{|c|}{ Floodway } & \multicolumn{4}{|c|}{ Base flood water-surface elevation } \\
\hline Cross section & $\begin{array}{l}\text { Cumulative } \\
\text { distance } \\
\text { upstream' } \\
\text { (ft) }\end{array}$ & $\begin{array}{l}\text { Width } \\
\text { (ft) }\end{array}$ & $\begin{array}{c}\text { Section area } \\
\left(\mathrm{ft}^{2}\right)\end{array}$ & $\begin{array}{l}\text { Mean velocity } \\
\text { (ft/s) }\end{array}$ & $\begin{array}{c}\text { Regulatory } \\
\text { (ft above } \\
\text { NGVD 29) }\end{array}$ & $\begin{array}{l}\text { Without } \\
\text { floodway } \\
\text { (ft above } \\
\text { NGVD 29) }\end{array}$ & $\begin{array}{c}\text { With } \\
\text { floodway } \\
\text { (ft above } \\
\text { NGVD 29) }\end{array}$ & $\begin{array}{c}\text { Increase } \\
\text { (ft) }\end{array}$ \\
\hline $\mathrm{DH}$ & $69,551.5$ & 557.2 & $1,590.1$ & 6.4 & 333.83 & 333.83 & 334.11 & 0.28 \\
\hline DI & $69,782.5$ & 921.3 & $3,512.6$ & 2.8 & 337.5 & 337.5 & 337.5 & 0 \\
\hline DJ & $70,007.5$ & 700.5 & $2,653.5$ & 3.7 & 337.77 & 337.77 & 337.77 & 0 \\
\hline DK & $70,500.5$ & 886.0 & $5,619.4$ & 1.8 & 338.1 & 338.1 & 338.1 & 0 \\
\hline DL & $70,812.5$ & 843.0 & $4,793.1$ & 2.1 & 338.21 & 338.21 & 338.21 & 0 \\
\hline DM & $71,388.5$ & 677.8 & $4,220.9$ & 2.3 & 338.36 & 338.36 & 338.36 & 0 \\
\hline $\mathrm{DN}$ & $71,616.5$ & 670.0 & $4,870.1$ & 2.0 & 338.38 & 338.38 & 338.49 & 0.11 \\
\hline DO & $72,165.5$ & 474.0 & $2,905.7$ & 3.4 & 338.47 & 338.47 & 338.56 & 0.09 \\
\hline DP & $74,512.5$ & 109.0 & $1,466.0$ & 6.7 & 339.51 & 339.51 & 339.98 & 0.47 \\
\hline DQ & $74,550.5$ & 170.0 & $2,019.8$ & 4.9 & 339.76 & 339.76 & 340.36 & 0.60 \\
\hline DR & $75,308.5$ & 216.6 & $2,479.9$ & 4.0 & 340.16 & 340.16 & 340.86 & 0.70 \\
\hline DS & $76,282.5$ & 223.6 & $2,645.5$ & 3.7 & 340.77 & 340.77 & 341.57 & 0.80 \\
\hline DT & $78,388.5$ & 563.2 & $5,146.8$ & 1.9 & 342.12 & 342.12 & 343.07 & 0.94 \\
\hline DU & $79,630.5$ & 604.8 & $4,846.4$ & 2.0 & 342.62 & 342.62 & 343.61 & 0.99 \\
\hline DV & $81,371.5$ & 733.8 & $6,301.8$ & 1.6 & 343.36 & 343.36 & 344.35 & 0.99 \\
\hline DW & $83,918.5$ & 307.4 & $3,246.9$ & 3.0 & 344.17 & 344.17 & 345.16 & 0.99 \\
\hline
\end{tabular}

${ }^{1}$ Feet upstream from confluence with Merrimack River $(1$ mile $=5,280 \mathrm{ft})$.

${ }^{2}$ Backwater from Merrimack River. 
THIS PAGE INTENTIONALLY LEFT BLANK 

Appendix 1. Suncook River 10-, 2-, 1- and 0.2-Percent Annual Exceedance Probability
Flood Profiles (10-, 50-, 100-, and 500-Year Recurrence-Interval Floods, respectively) 


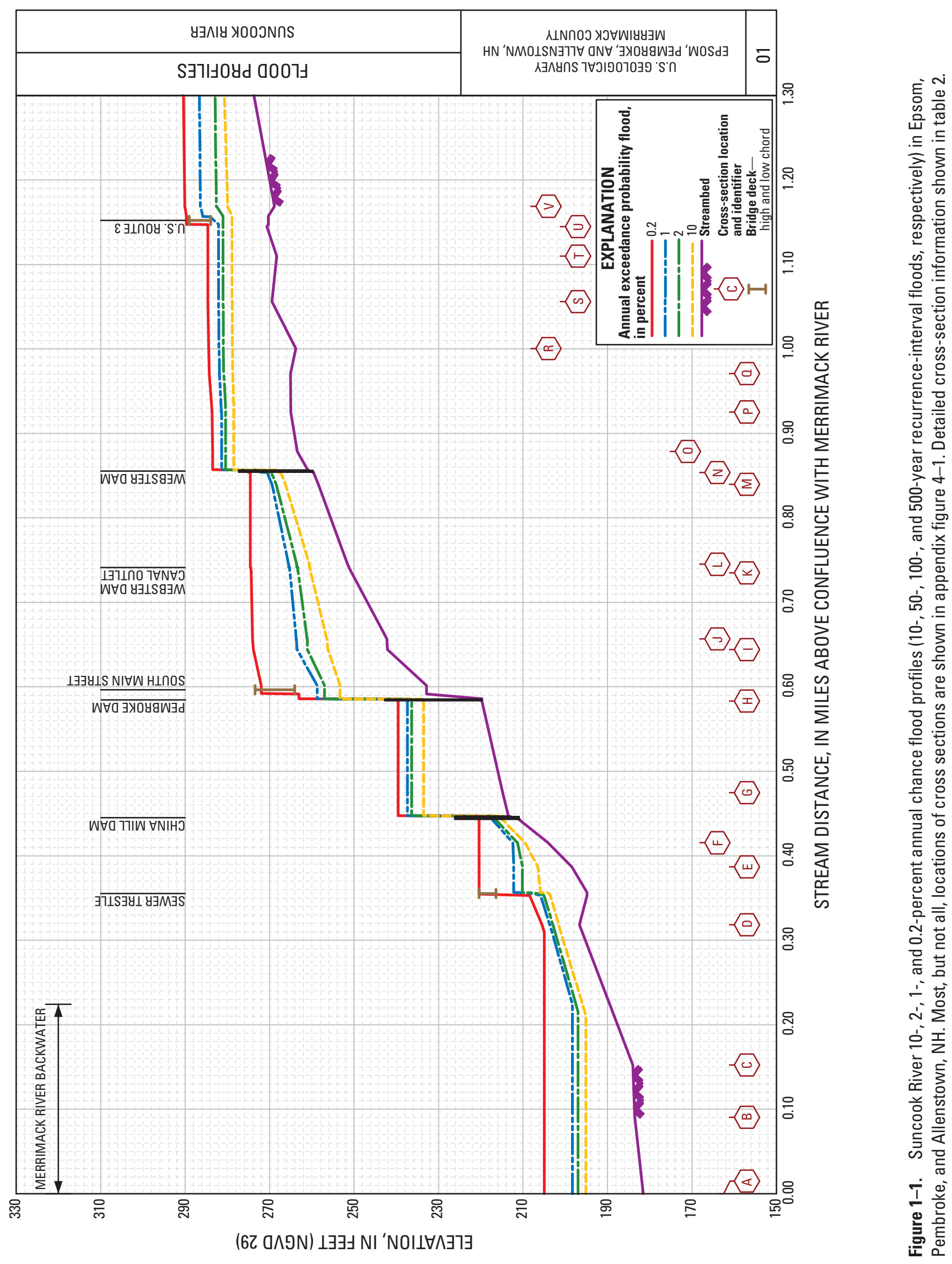




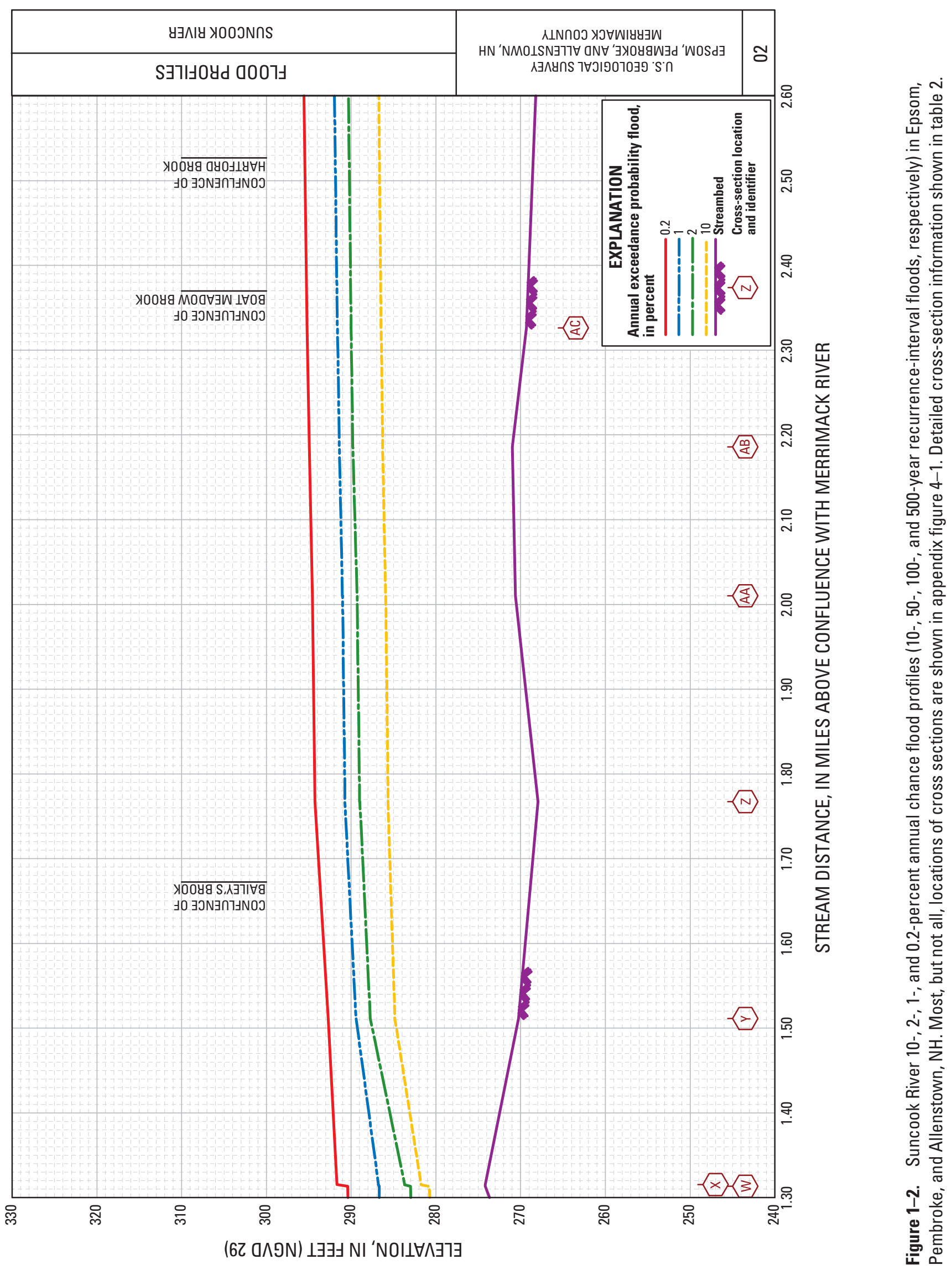




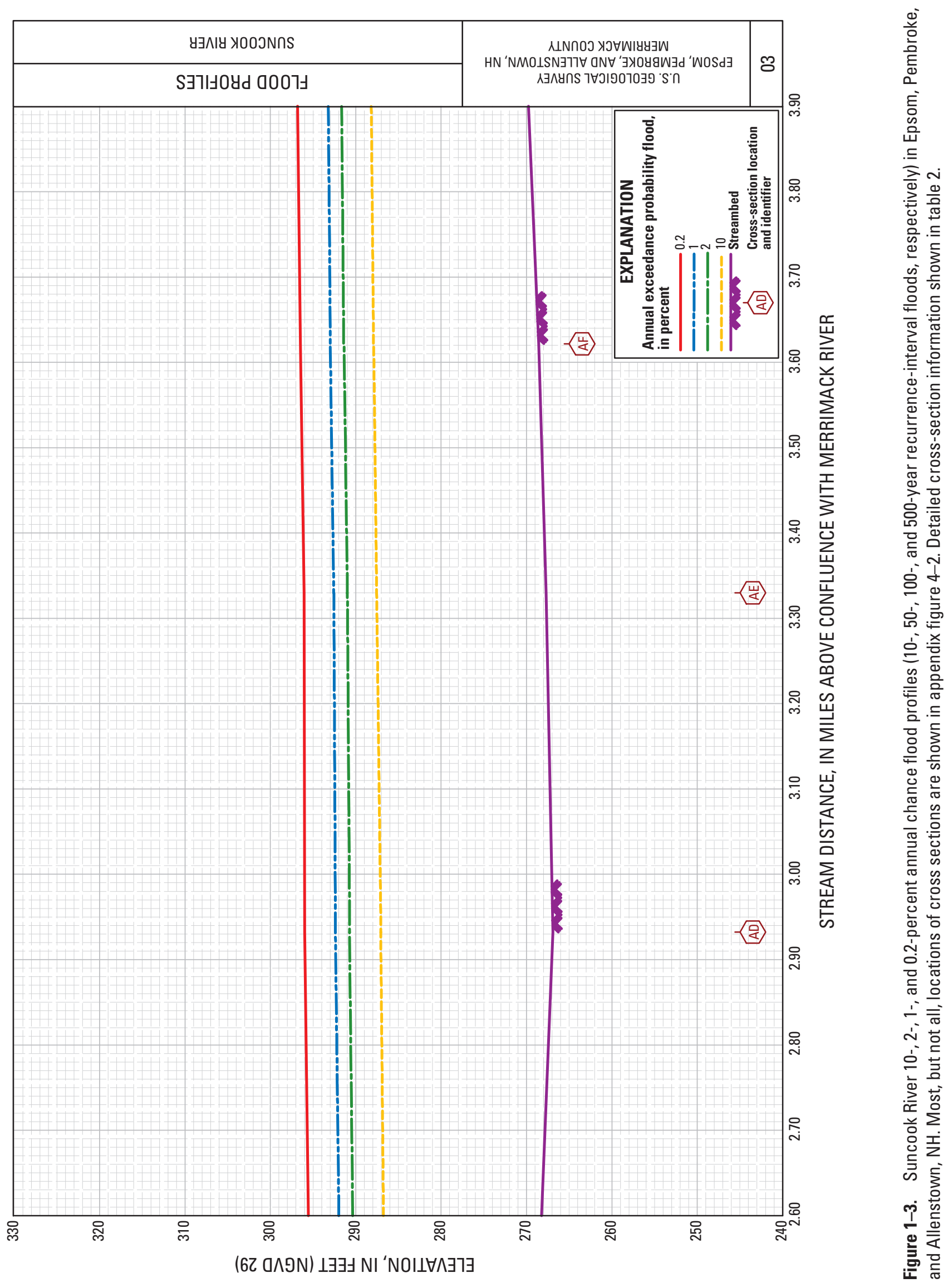




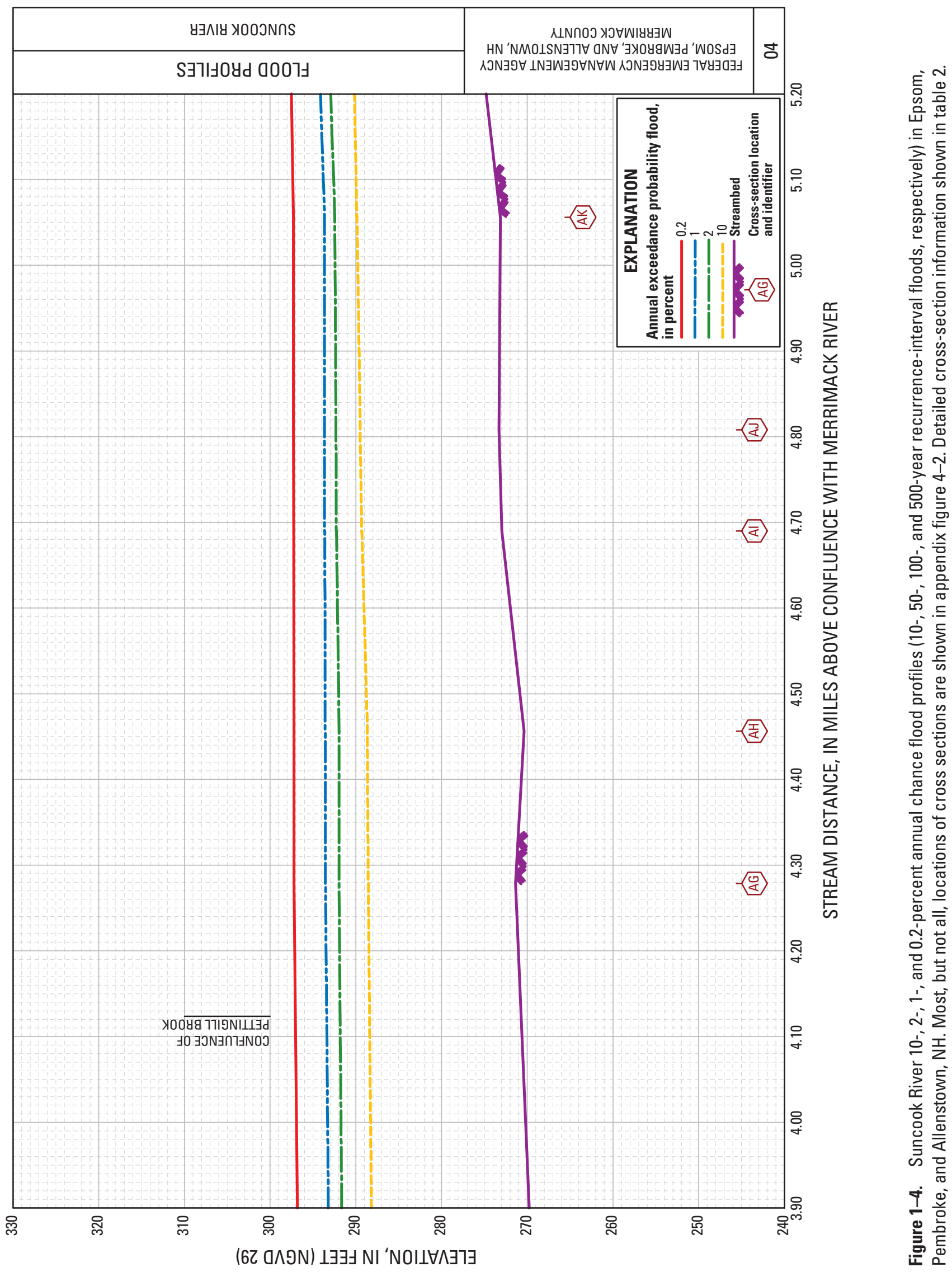




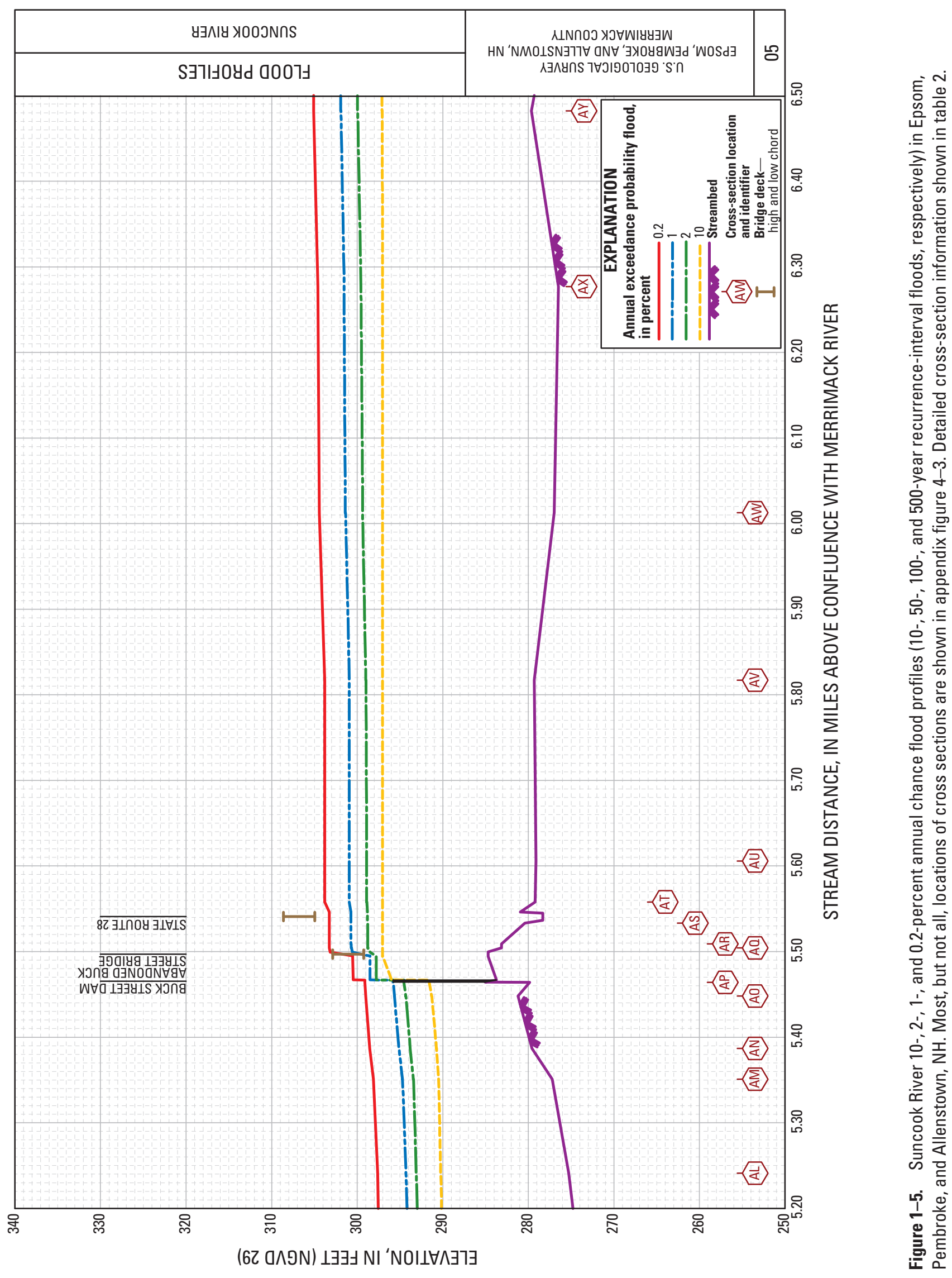




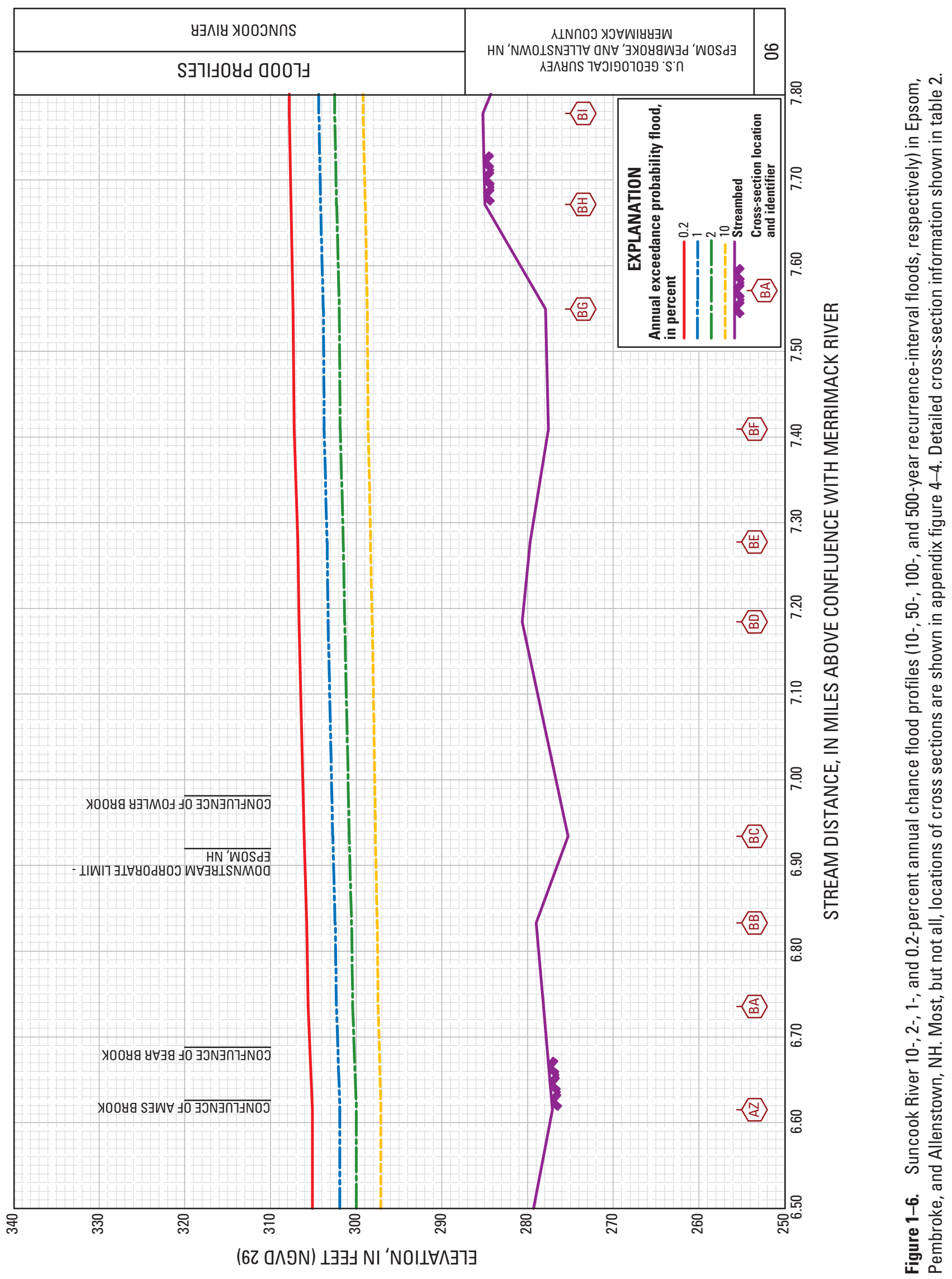




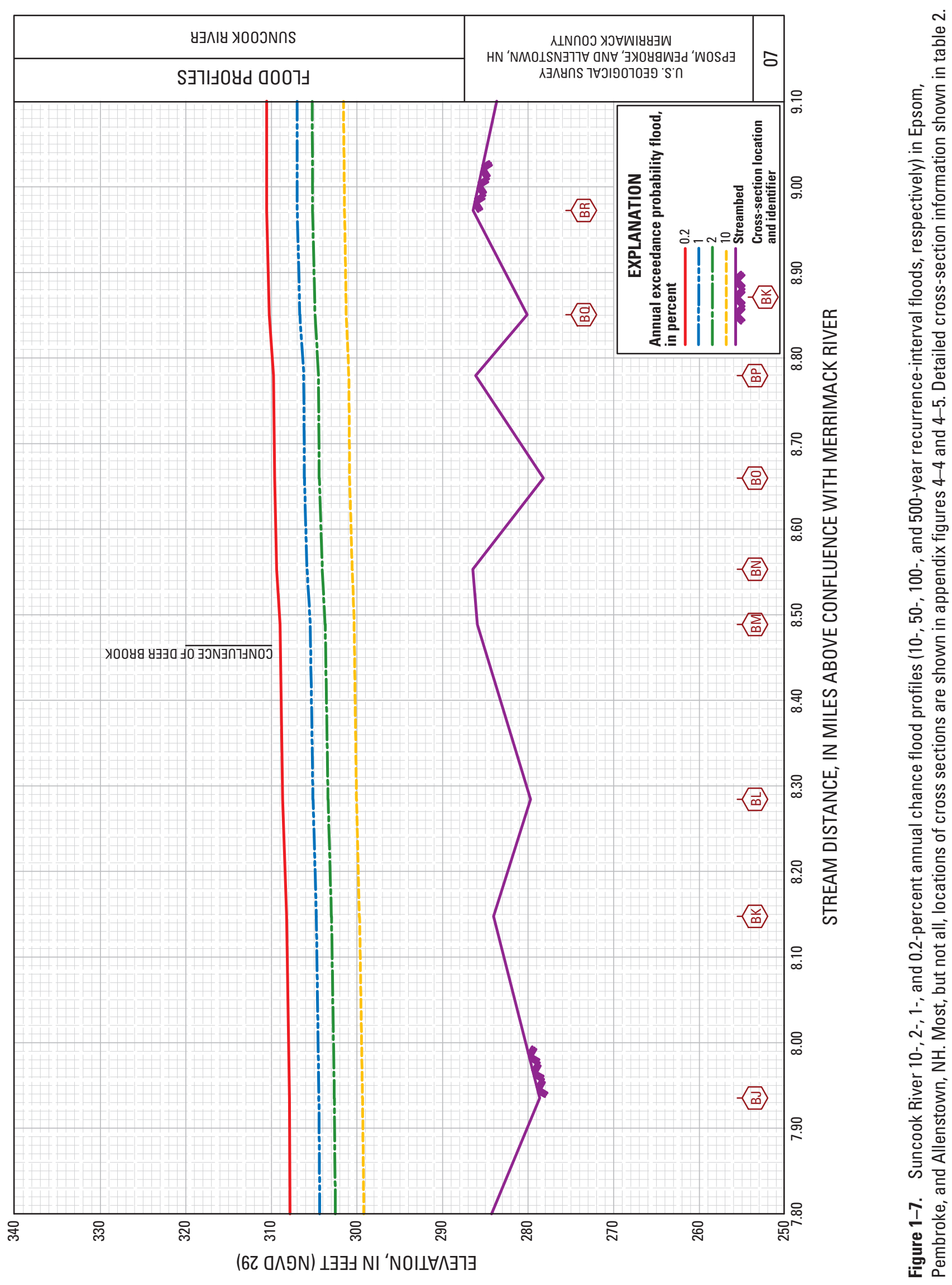




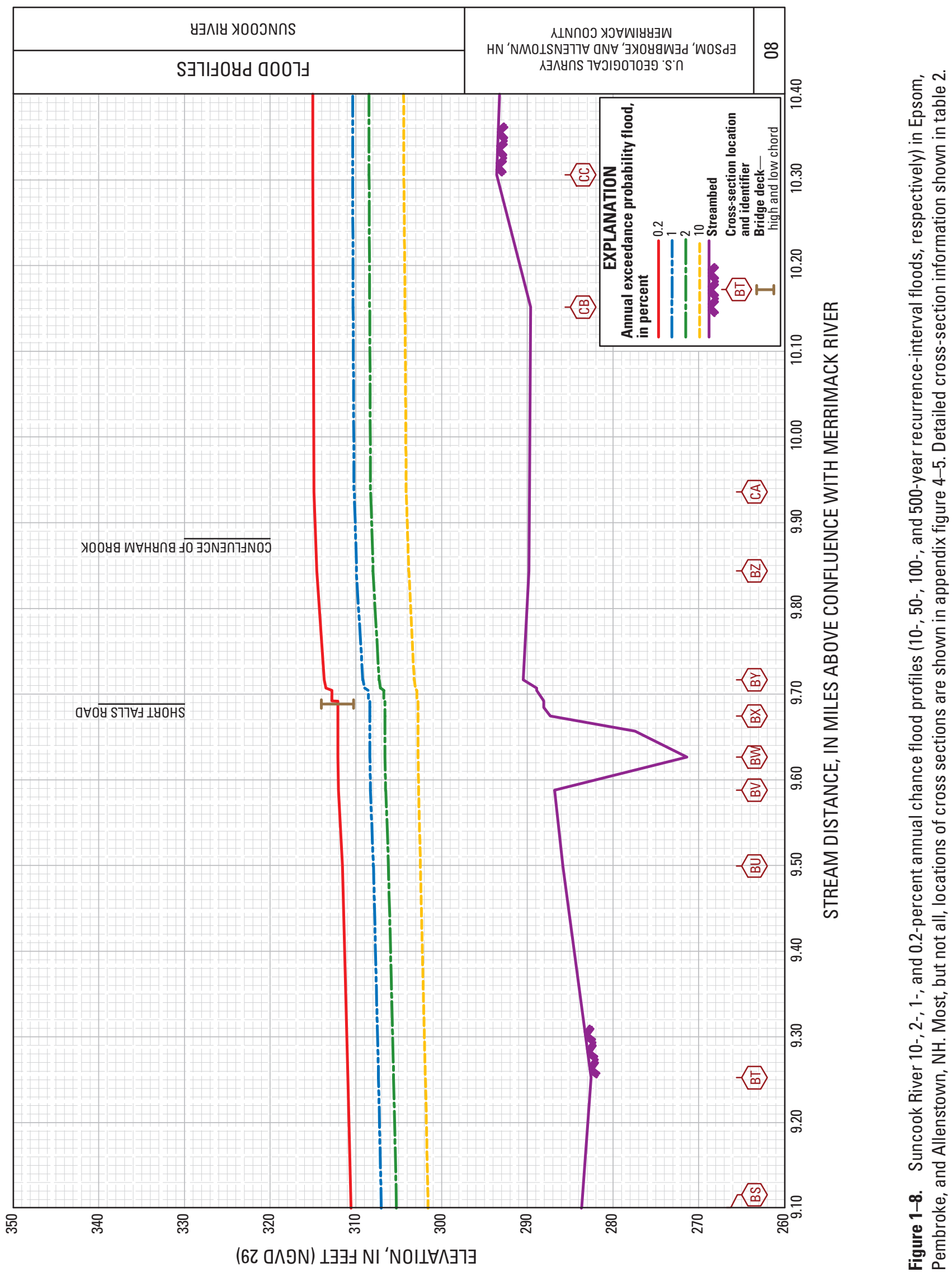




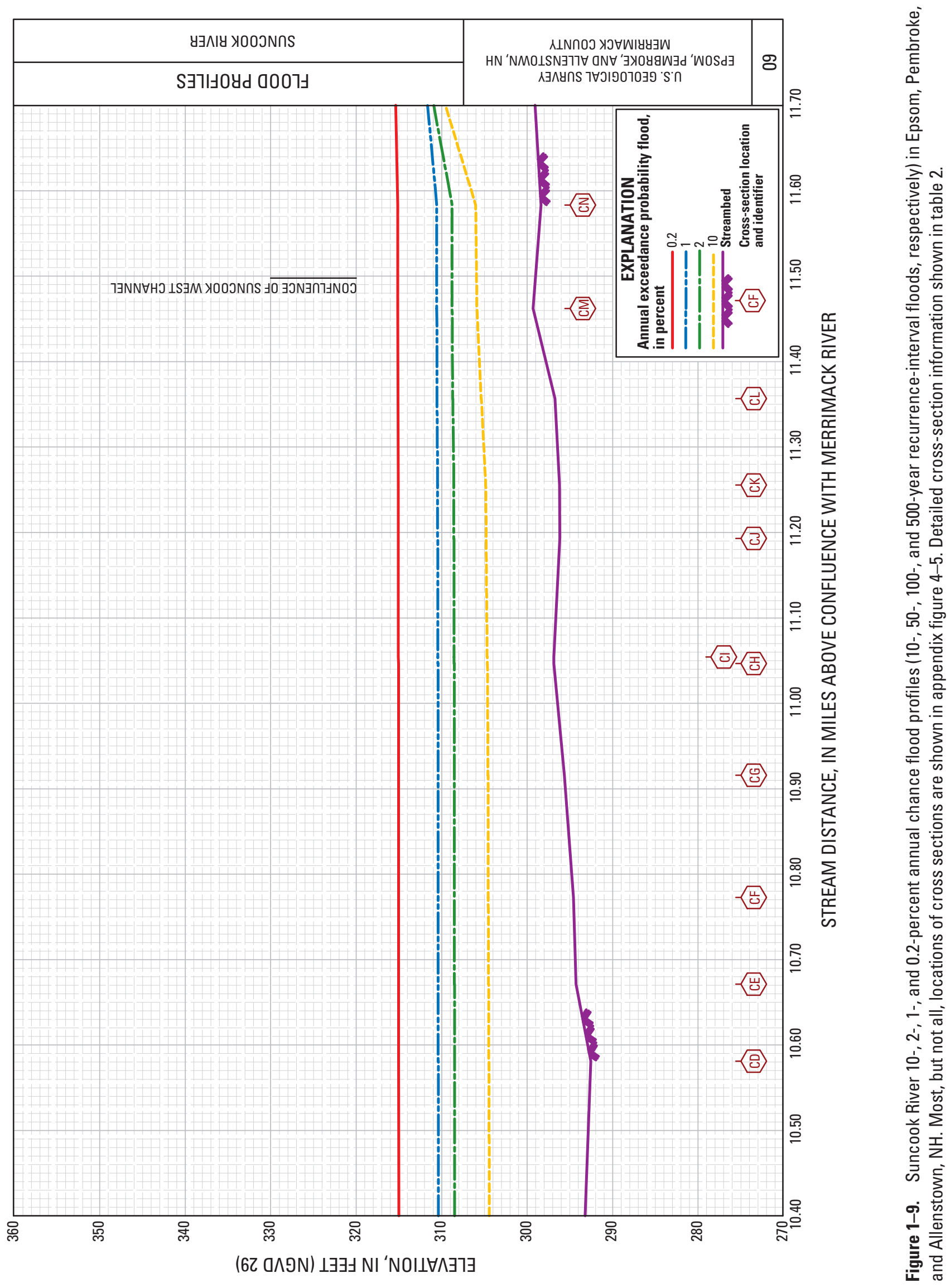




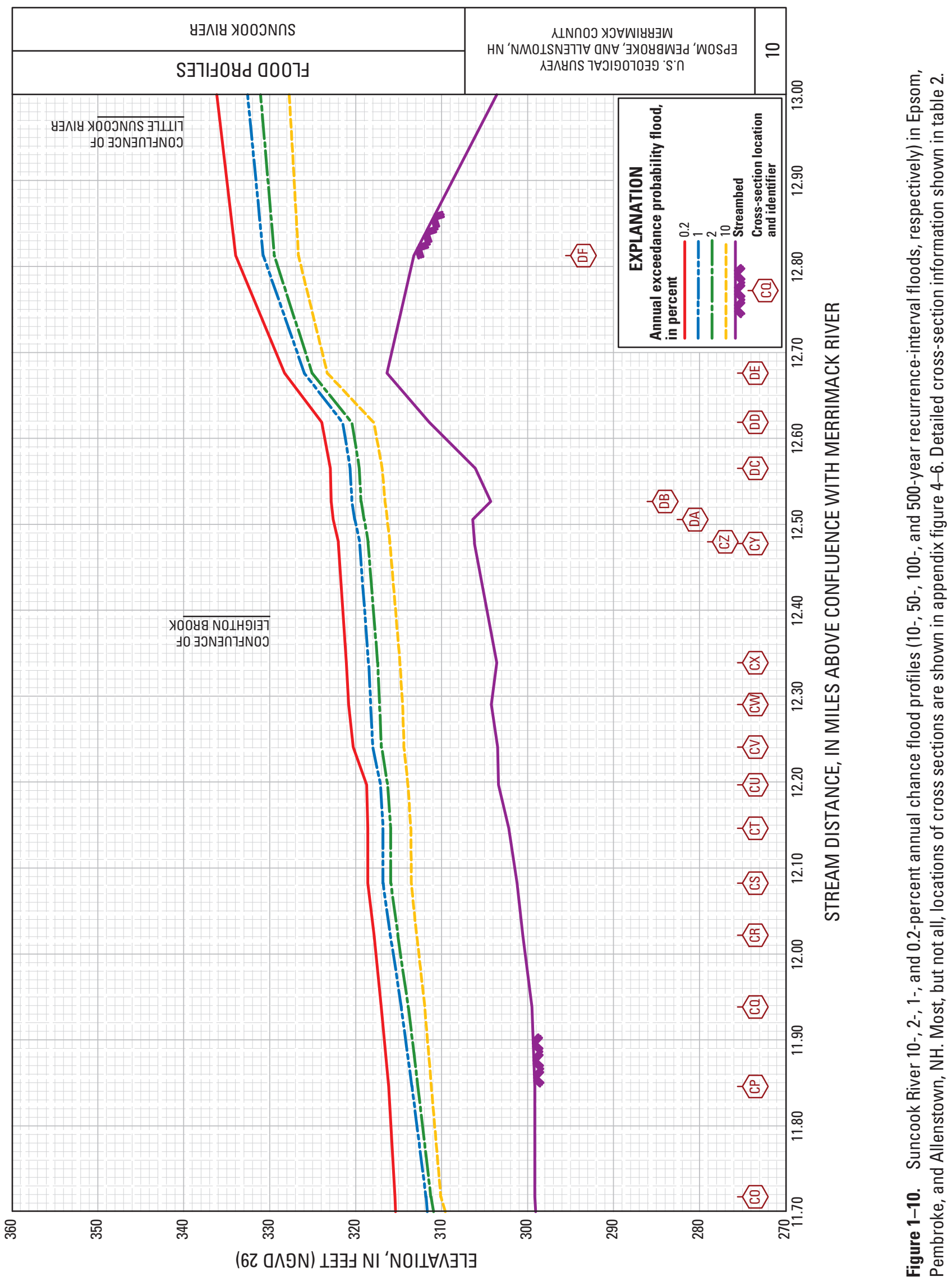




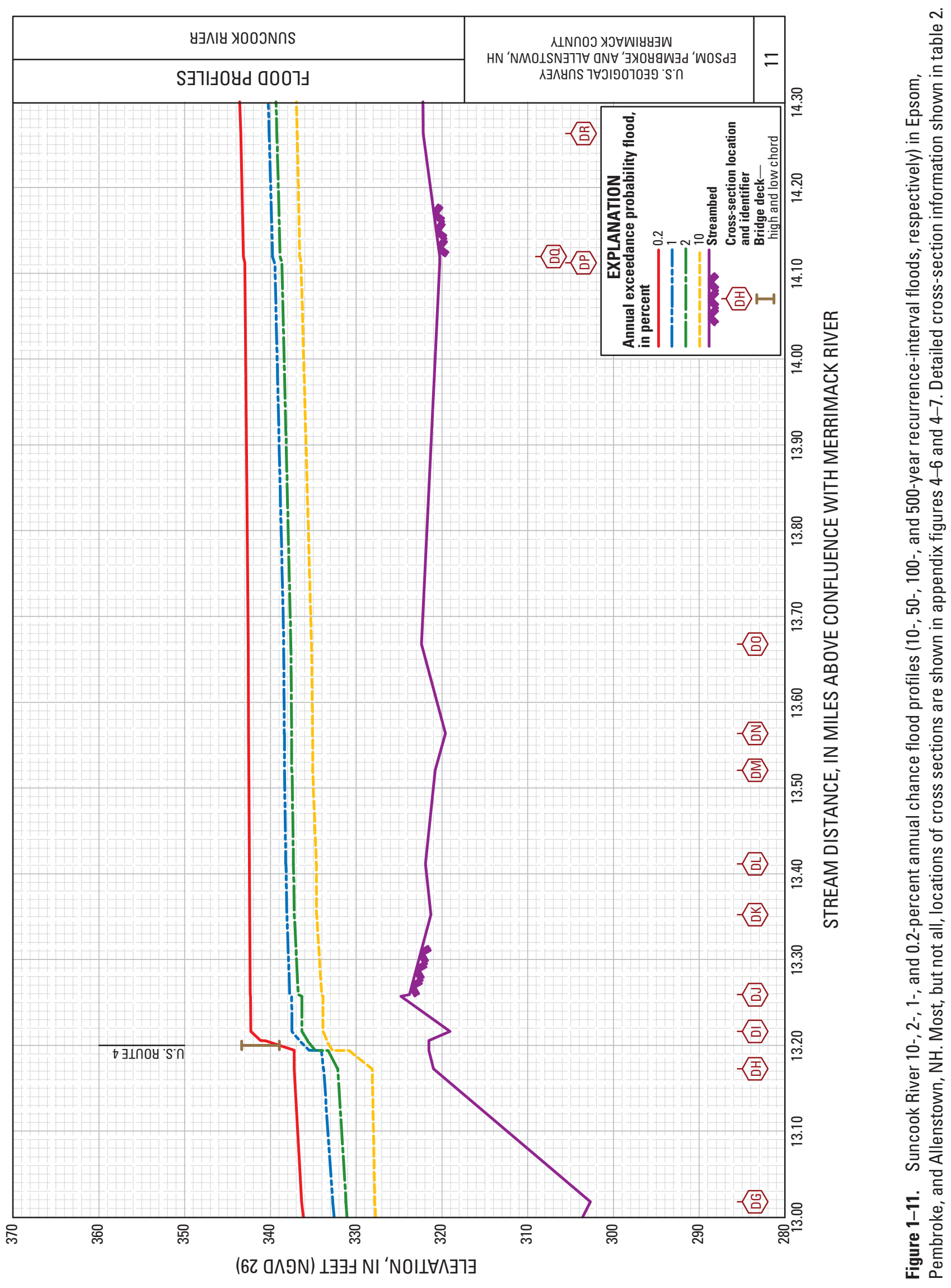




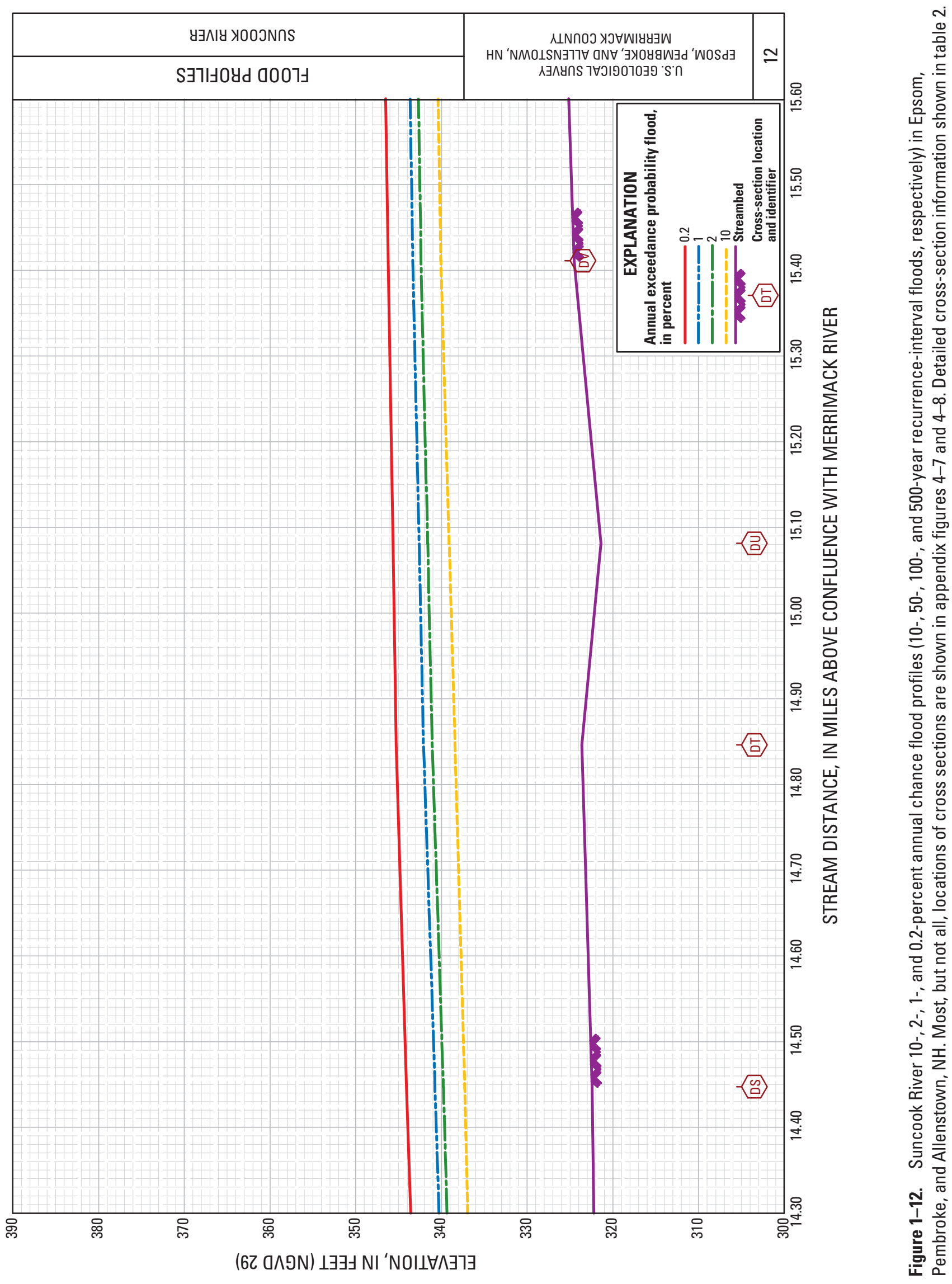




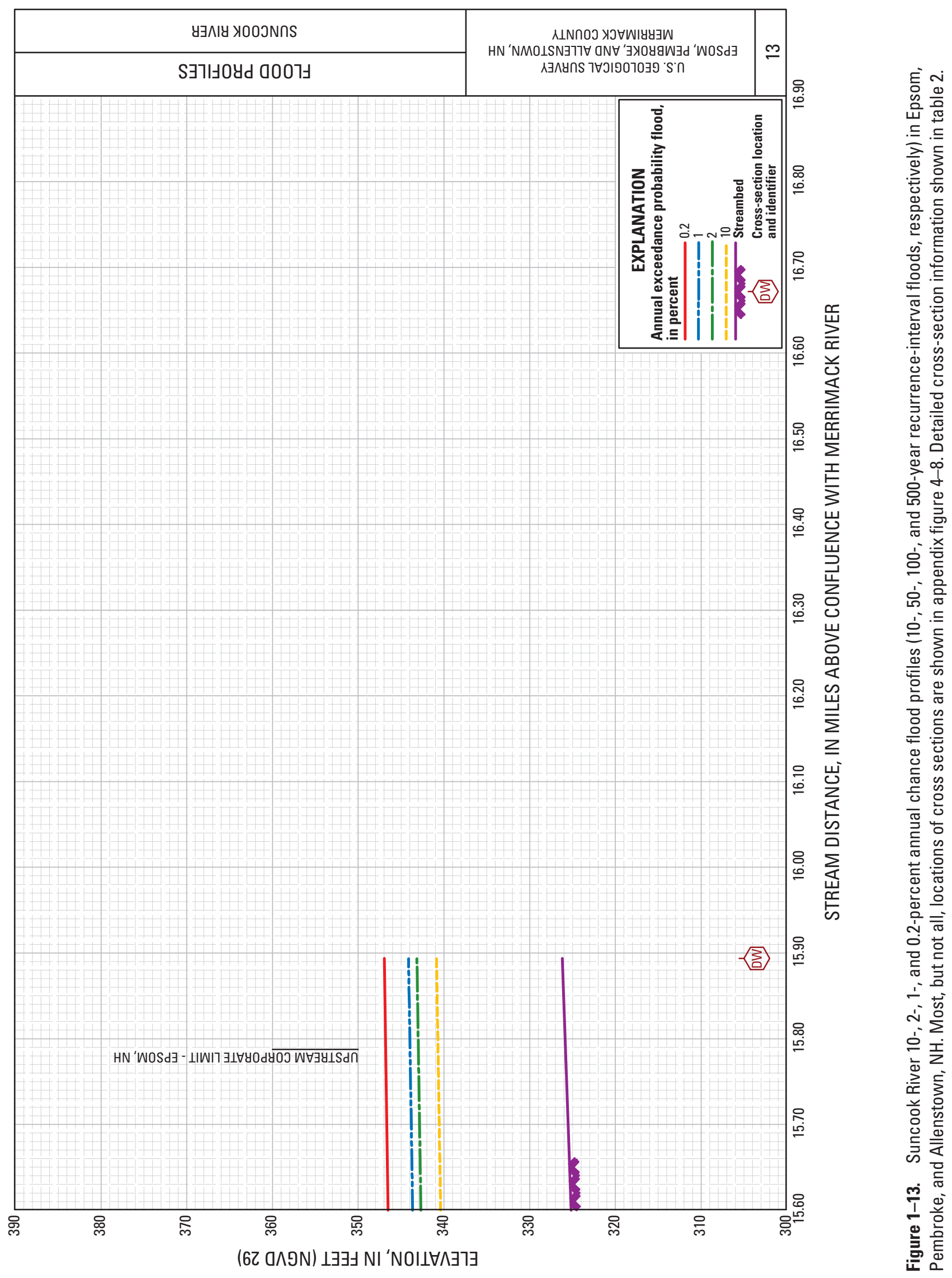




\section{Appendix 2. Suncook River April 2007 Flood and 50-, 20-, and 4-Percent Annual Exceedance Probability Flood Profiles (2-, 5-, and 25-Year Recurrence-Interval Floods, respectively)}




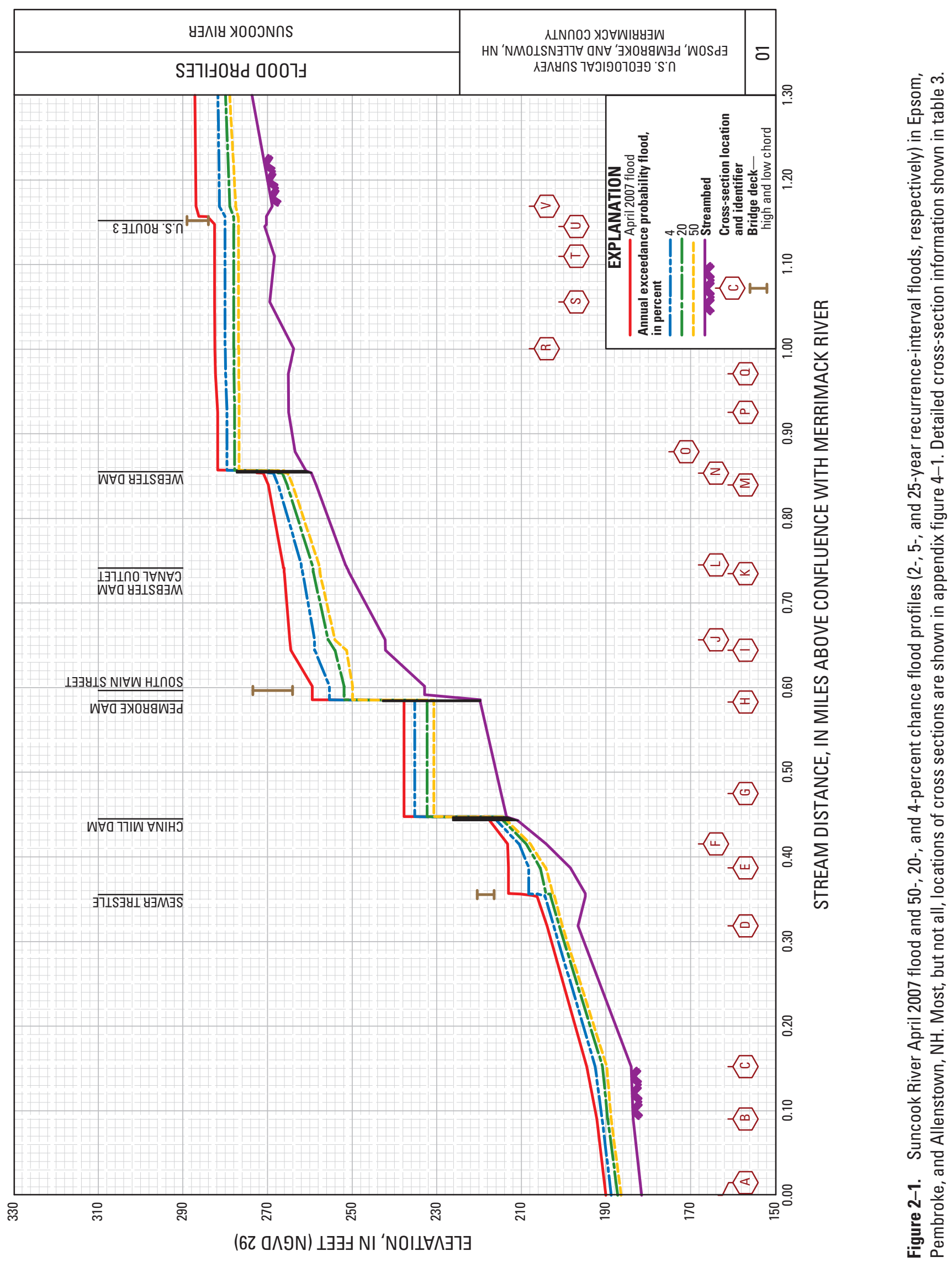




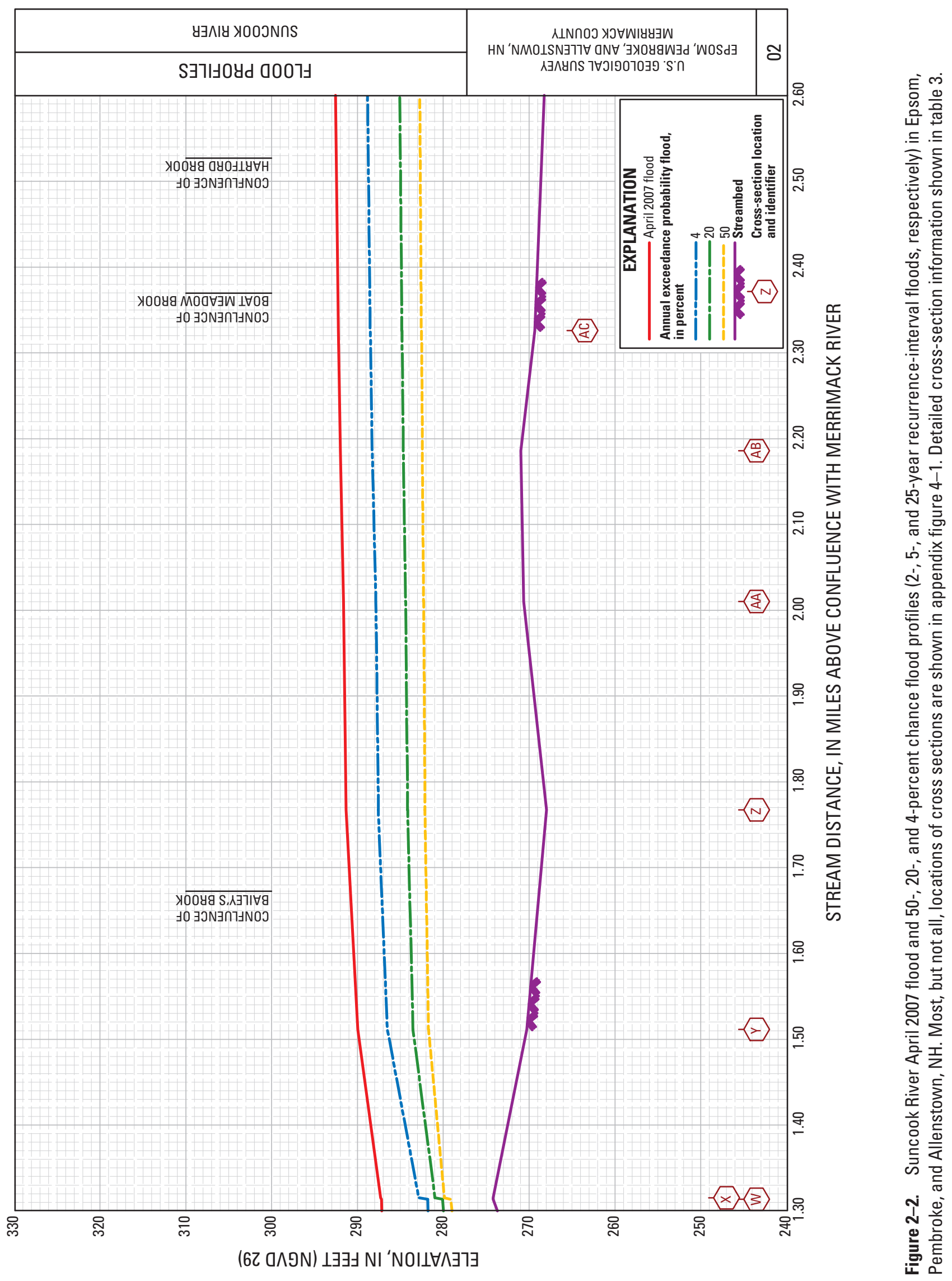




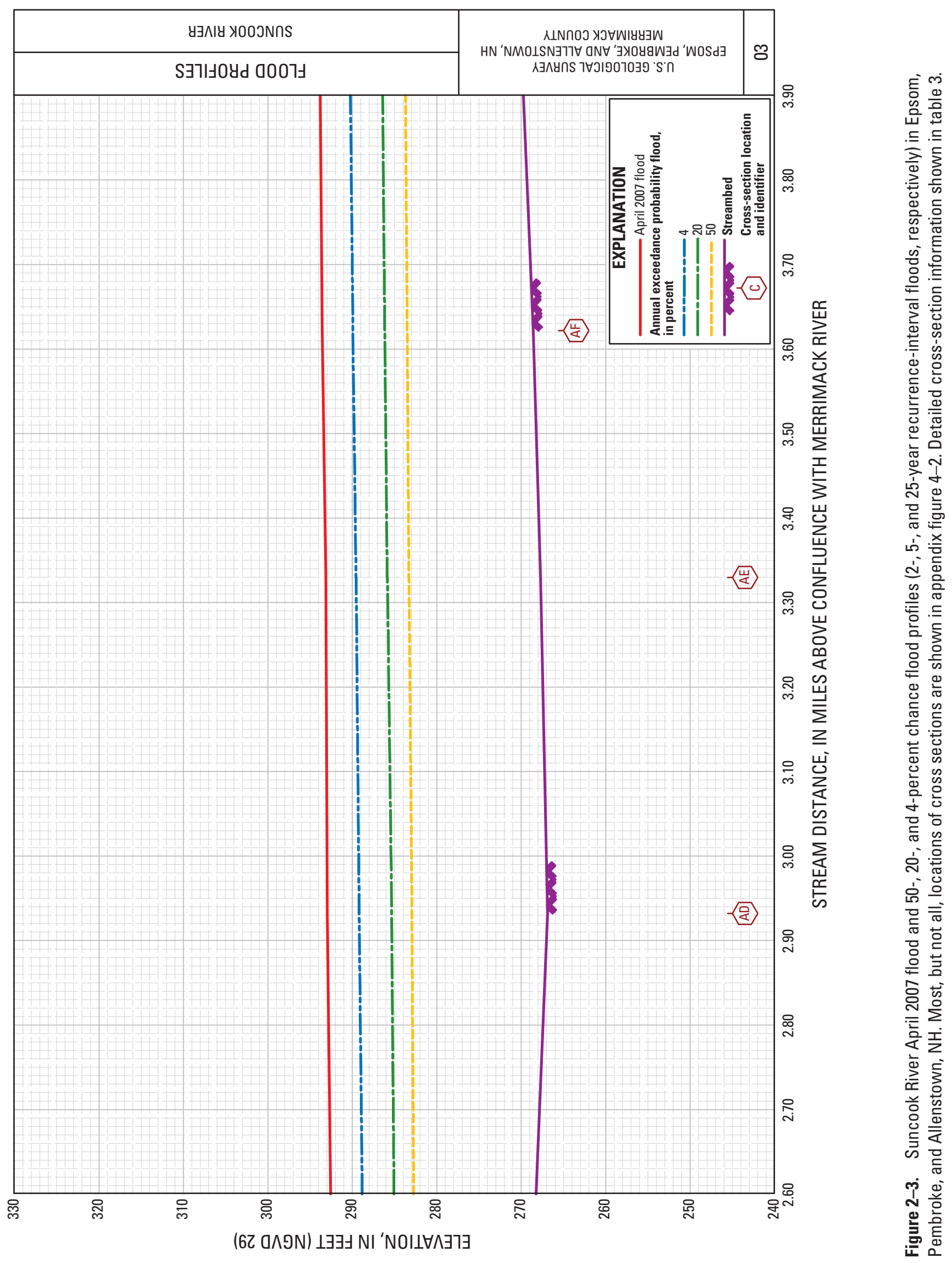




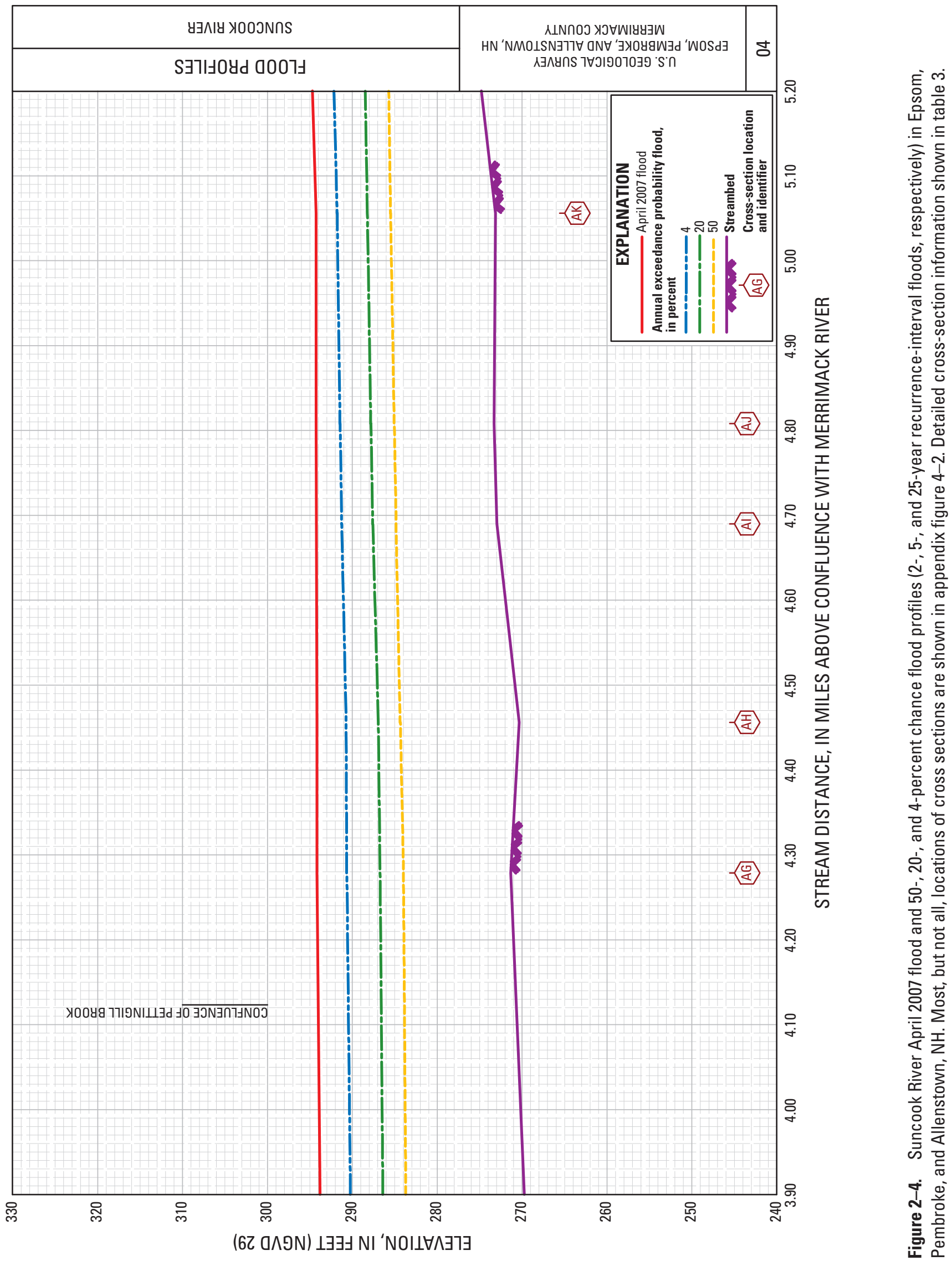




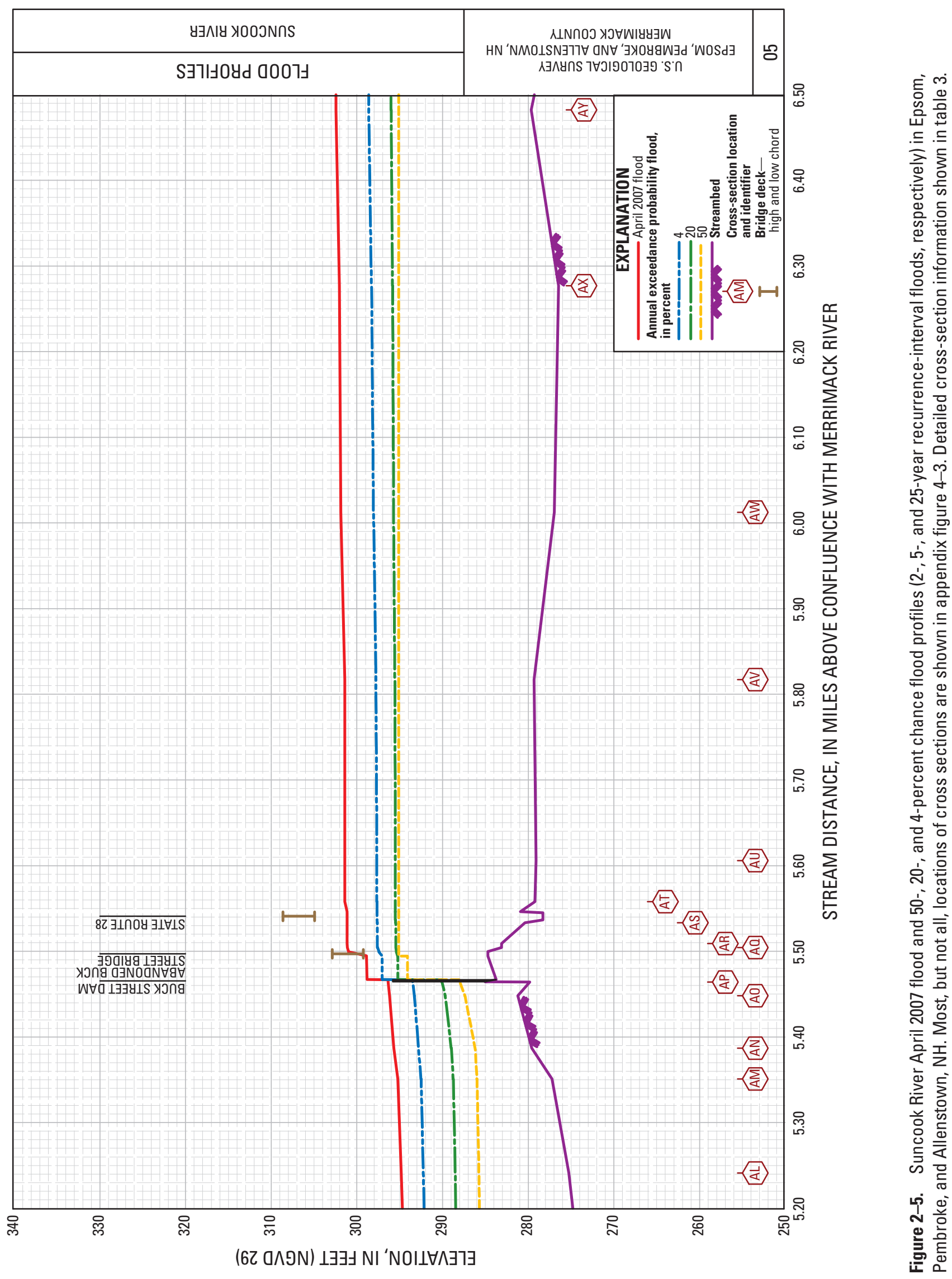




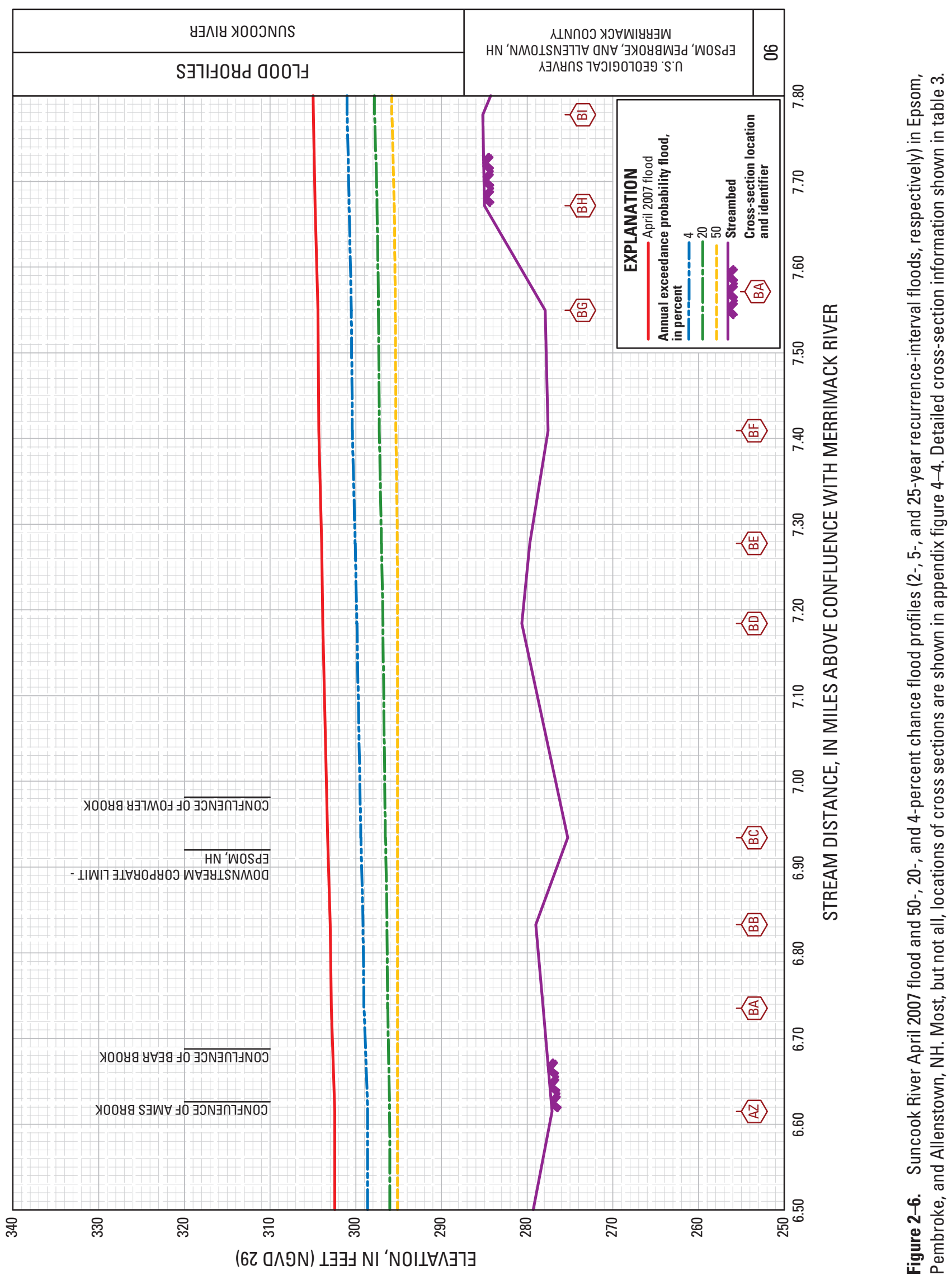




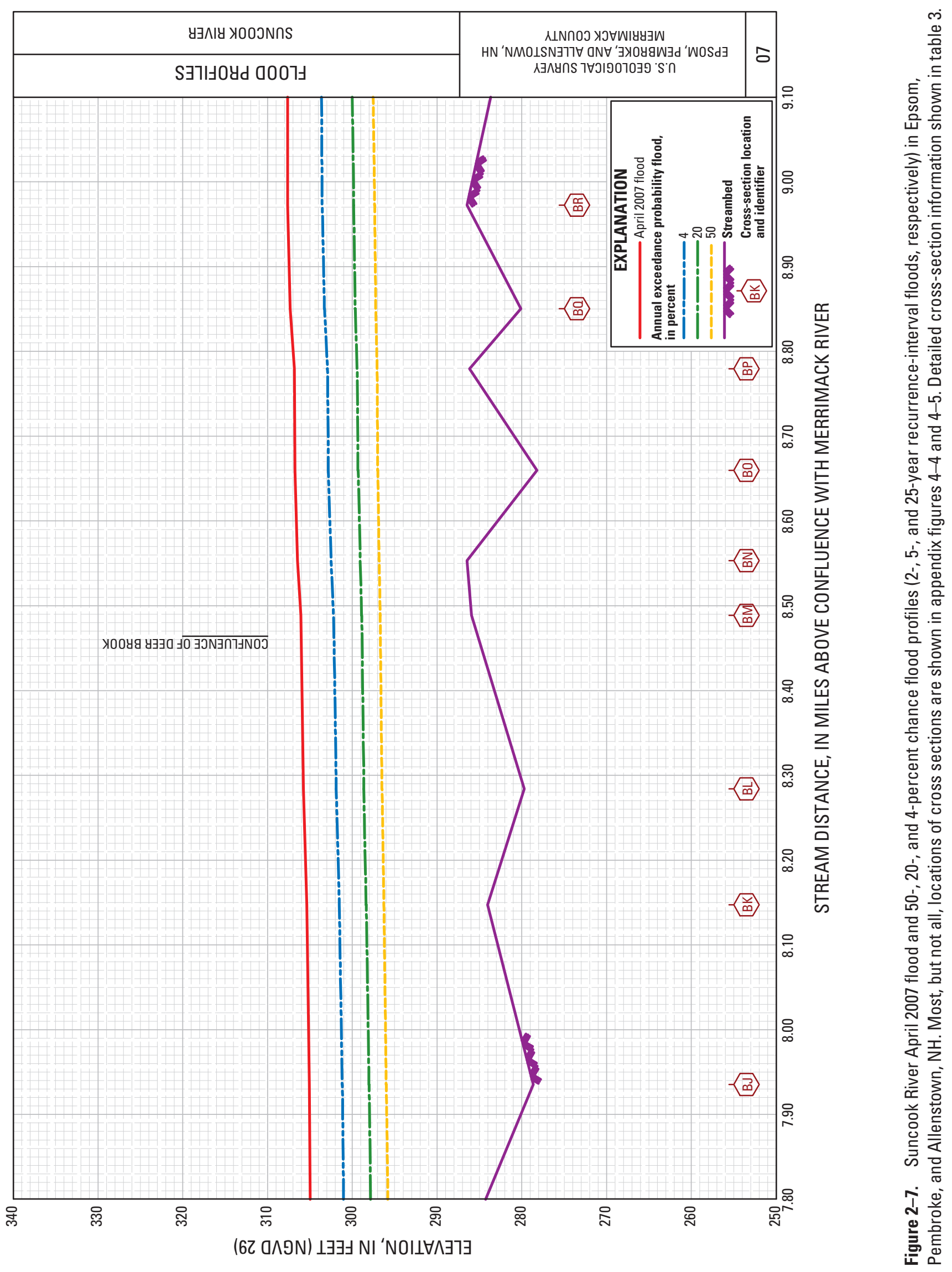




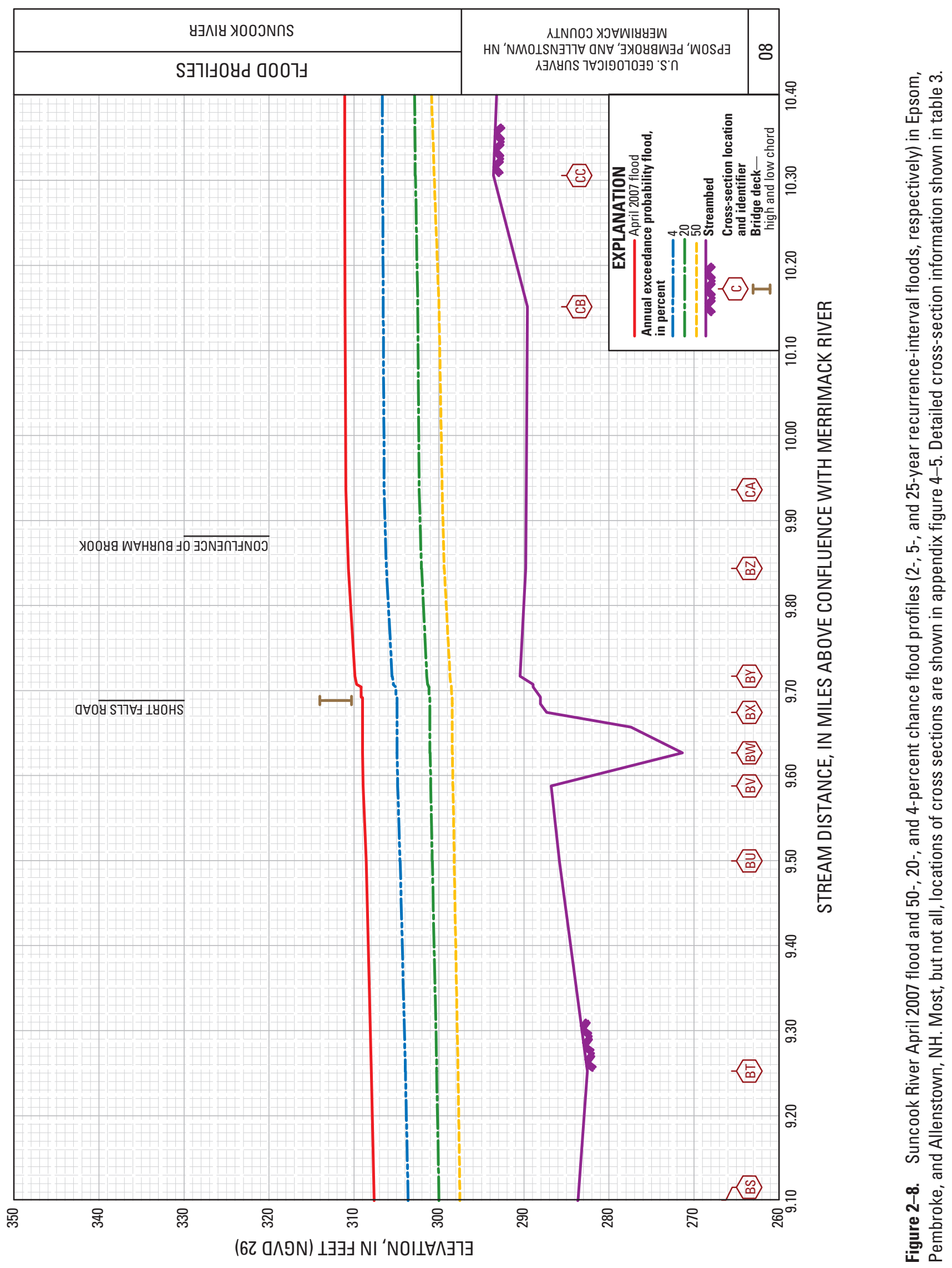




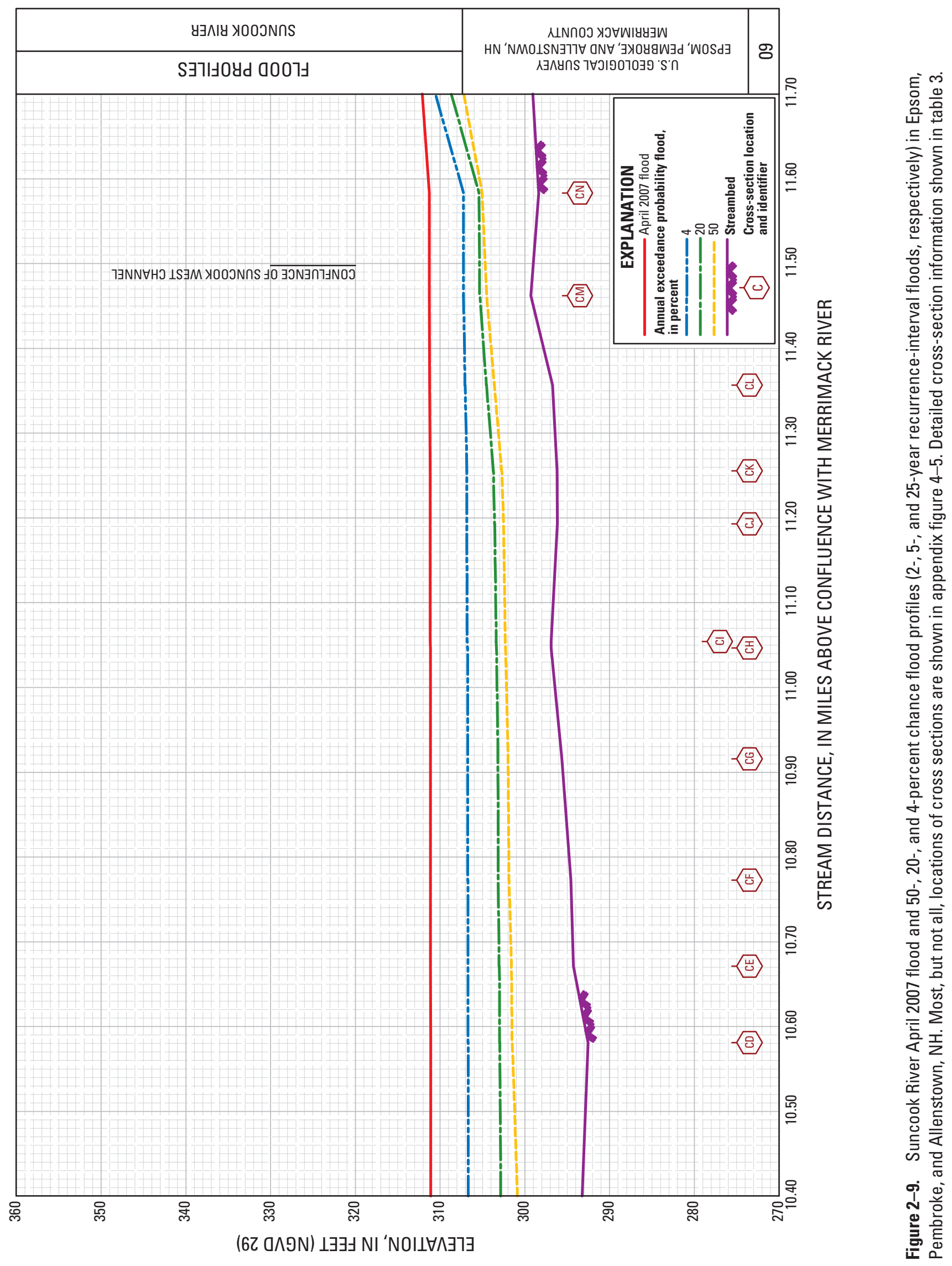




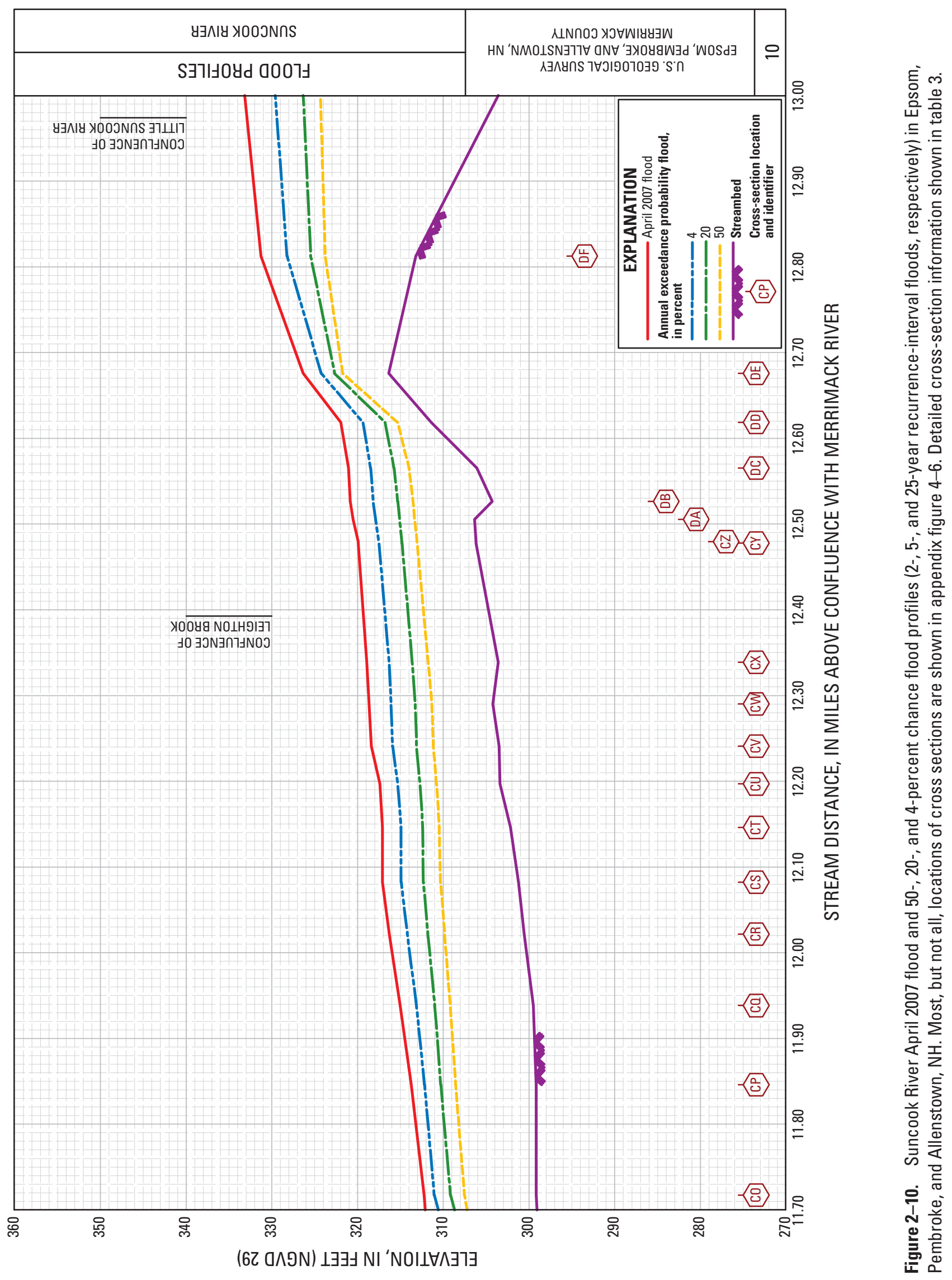




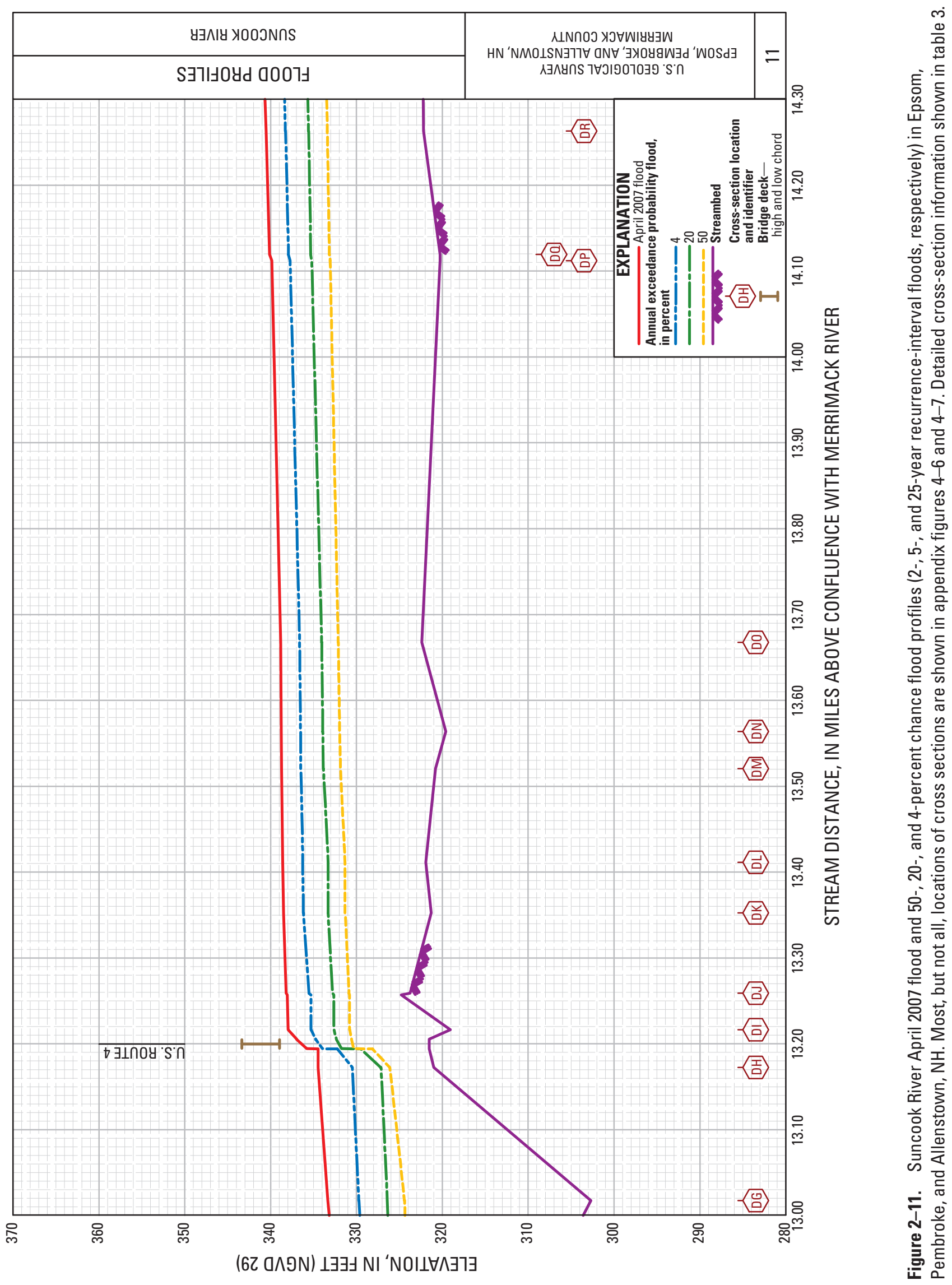




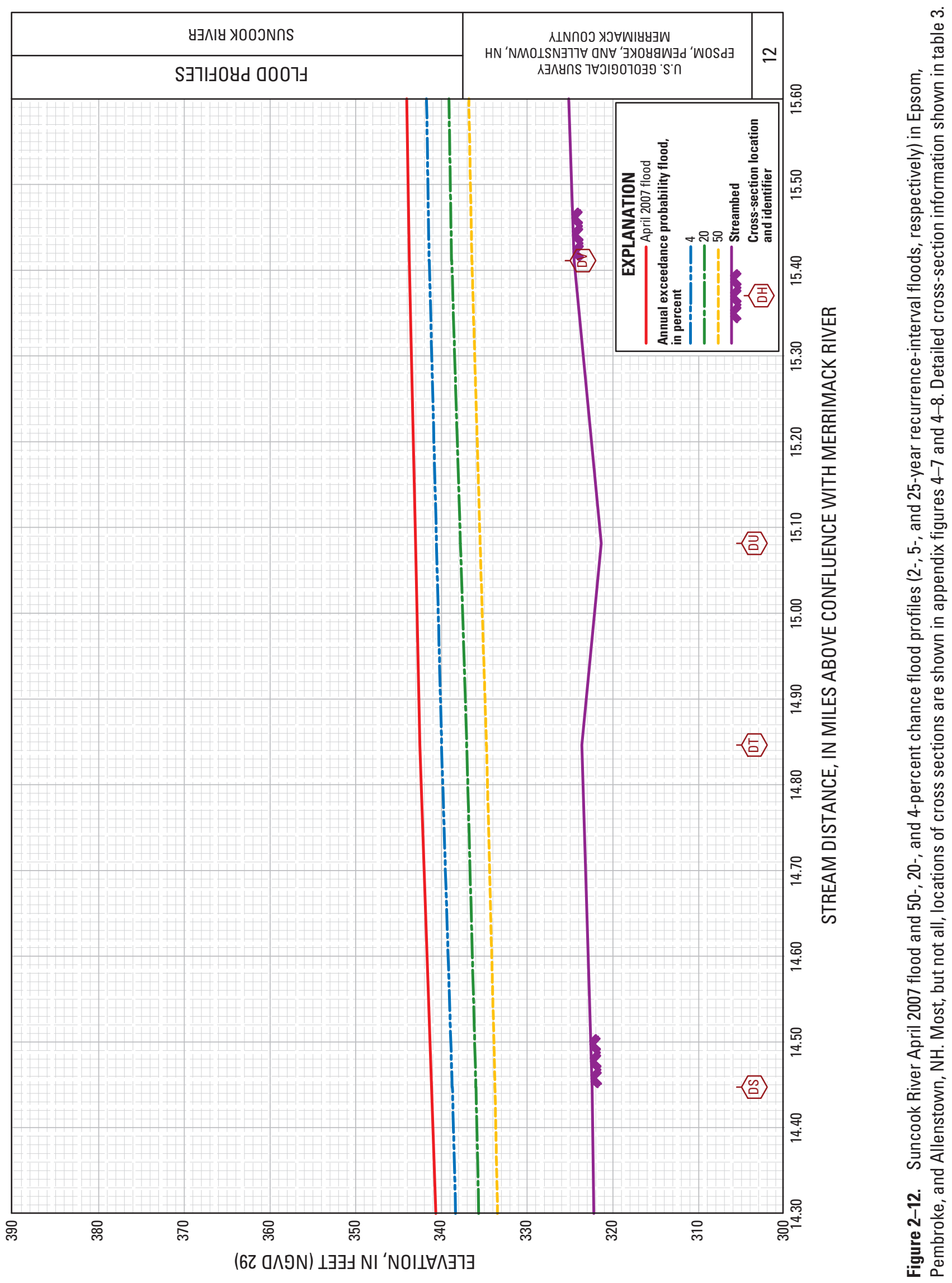




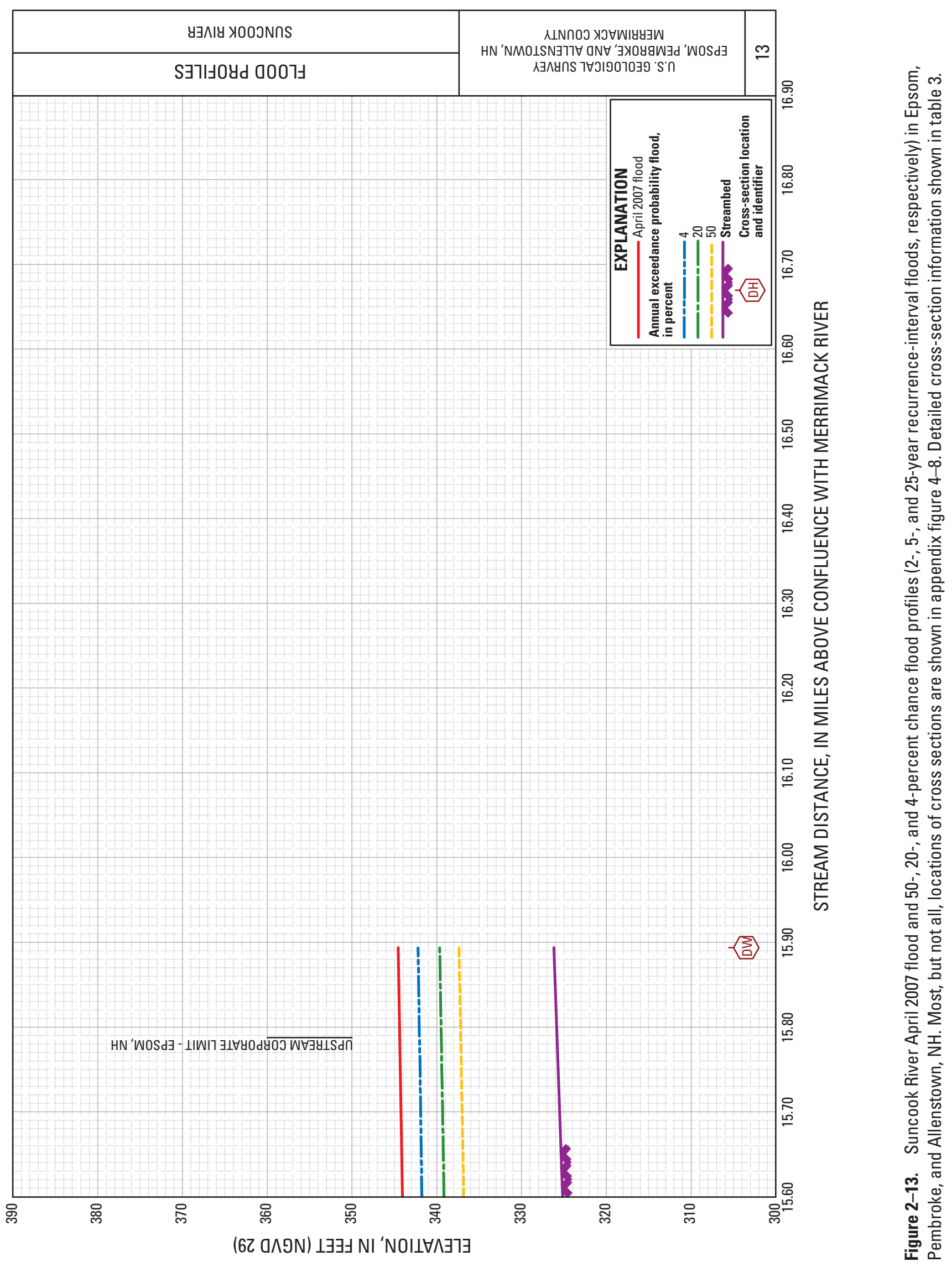




\section{Appendix 3. Elevation Reference Marks}


Appendix 3. Elevation reference marks.

[ft, feet; NGVD 29, National Geodetic Vertical Datum of 1929; degrees; USCGS, U.S. Coast and Geodetic Survey; USGS, U.S. Geological Survey; NHDPWH, N.H. Department of Public Works and Highways]

\begin{tabular}{|c|c|c|}
\hline Reference mark & $\begin{array}{l}\text { Elevation } \\
\text { (ft above } \\
\text { NGVD 29) }\end{array}$ & Description of location \\
\hline $\begin{array}{l}\text { D } 191934 \\
\left(44^{\circ} 11^{\prime} 49^{\prime \prime} \mathrm{N}, 71^{\circ} 22^{\prime} 17^{\prime \prime} \mathrm{W}\right)\end{array}$ & 354.28 & $\begin{array}{l}\text { Standard USGS disk stamped "D } 19 \text { 1934" and set in a } 25 \times 25 \mathrm{ft} \text { partially } \\
\text { exposed ledge, } 10.0 \mathrm{ft} \text { above the road. Located } 84.0 \mathrm{ft} \text { east-southeast from } \\
\text { the center of River Road, } 45.0 \mathrm{ft} \text { south-southwest from a stonewall, and } \\
103 \mathrm{ft} \text { east-northeast from the northeast corner of a white house. }\end{array}$ \\
\hline $\begin{array}{l}1149-0160 \\
\left(43^{\circ} 13^{\prime} 31.77^{\prime \prime} \mathrm{N}, 71^{\circ} 21^{\prime} 44.97^{\prime \prime} \mathrm{W}\right)\end{array}$ & 368.09 & $\begin{array}{l}\text { Standard NHDPWH disk stamped " } 1149-0160 \text { " and set into the top of a } 5 \text { - } \mathrm{ft} \\
\text { rock ledge } 1.5 \mathrm{ft} \text { above the ground, } 32.0 \mathrm{ft} \text { east from the center of the } \\
\text { Rte. } 28,121 \mathrm{ft} \text { southwest from power pole } \mathrm{CE} / 3 \mathrm{~A} / \mathrm{CO}, 112 \mathrm{ft} \text { south-south- } \\
\text { west from the center of an iron-covered sewer manhole, } 23.0 \mathrm{ft} \text { west from } \\
\text { the woods line. }\end{array}$ \\
\hline $\begin{array}{l}\text { TВМ } 364364.567 \\
\left(43^{\circ} 14^{\prime} 25^{\prime \prime} \mathrm{N}, 71^{\circ} 21^{\prime} 40^{\prime \prime} \mathrm{W}\right)\end{array}$ & 364.57 & $\begin{array}{l}\text { Standard rivet set in an embedded boulder } 15.0 \mathrm{ft} \text { above an abandoned railroad } \\
\text { bed and } 3.0 \mathrm{ft} \text { above the ground. Located } 36.0 \mathrm{ft} \text { east from the abandoned } \\
\text { railroad bed, approximately } 500 \mathrm{ft} \text { west of Goboro Road and much lower in } \\
\text { a wooded area behind a small field. }\end{array}$ \\
\hline
\end{tabular}


Appendix 4. Suncook River Flood Map of the Floodway, and the 100- and 500-Year Flood from the Confluence with the Merrimack River to the Upstream Corporate Limit of Epsom, New Hampshire 


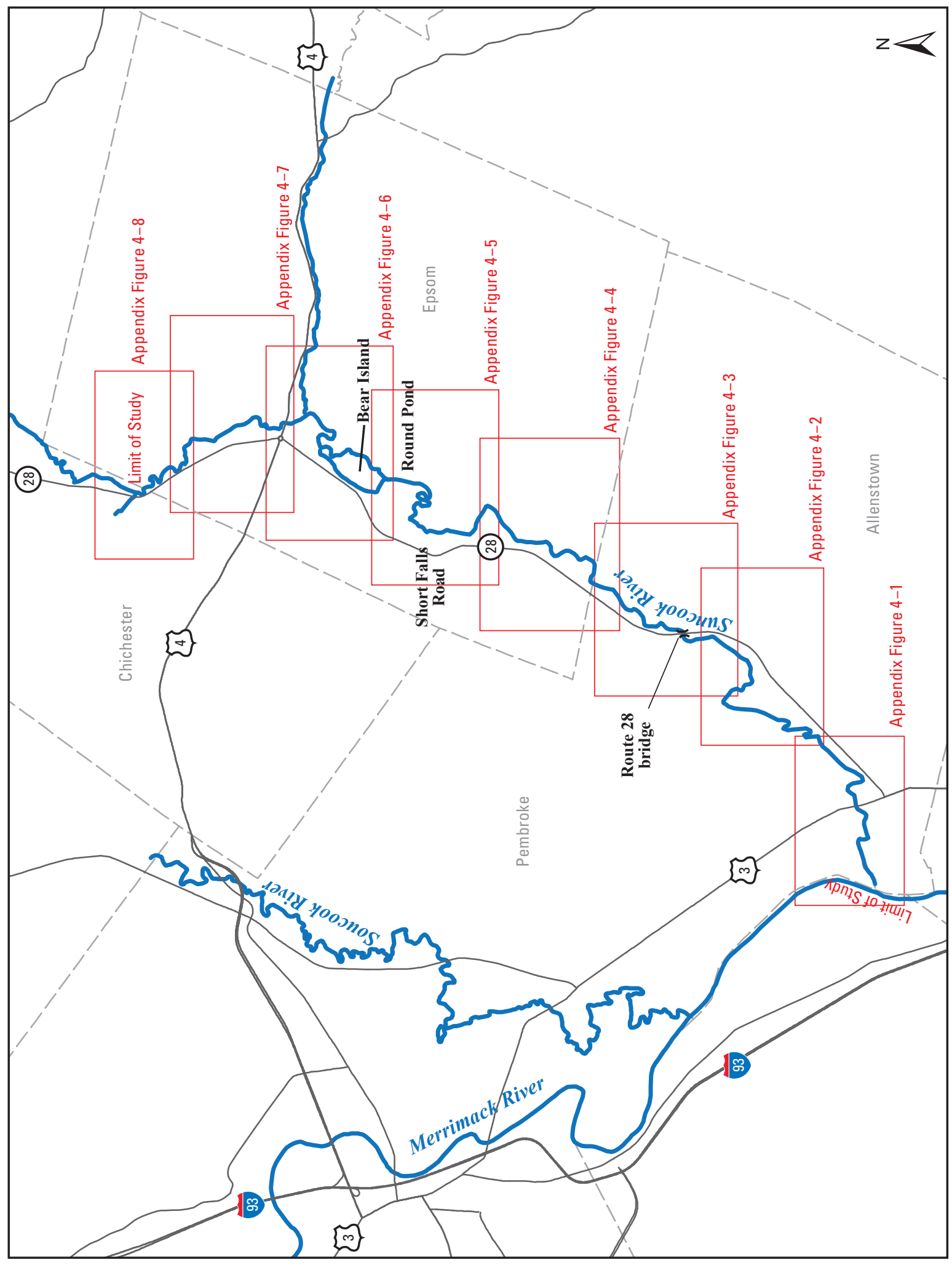

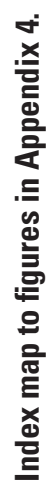




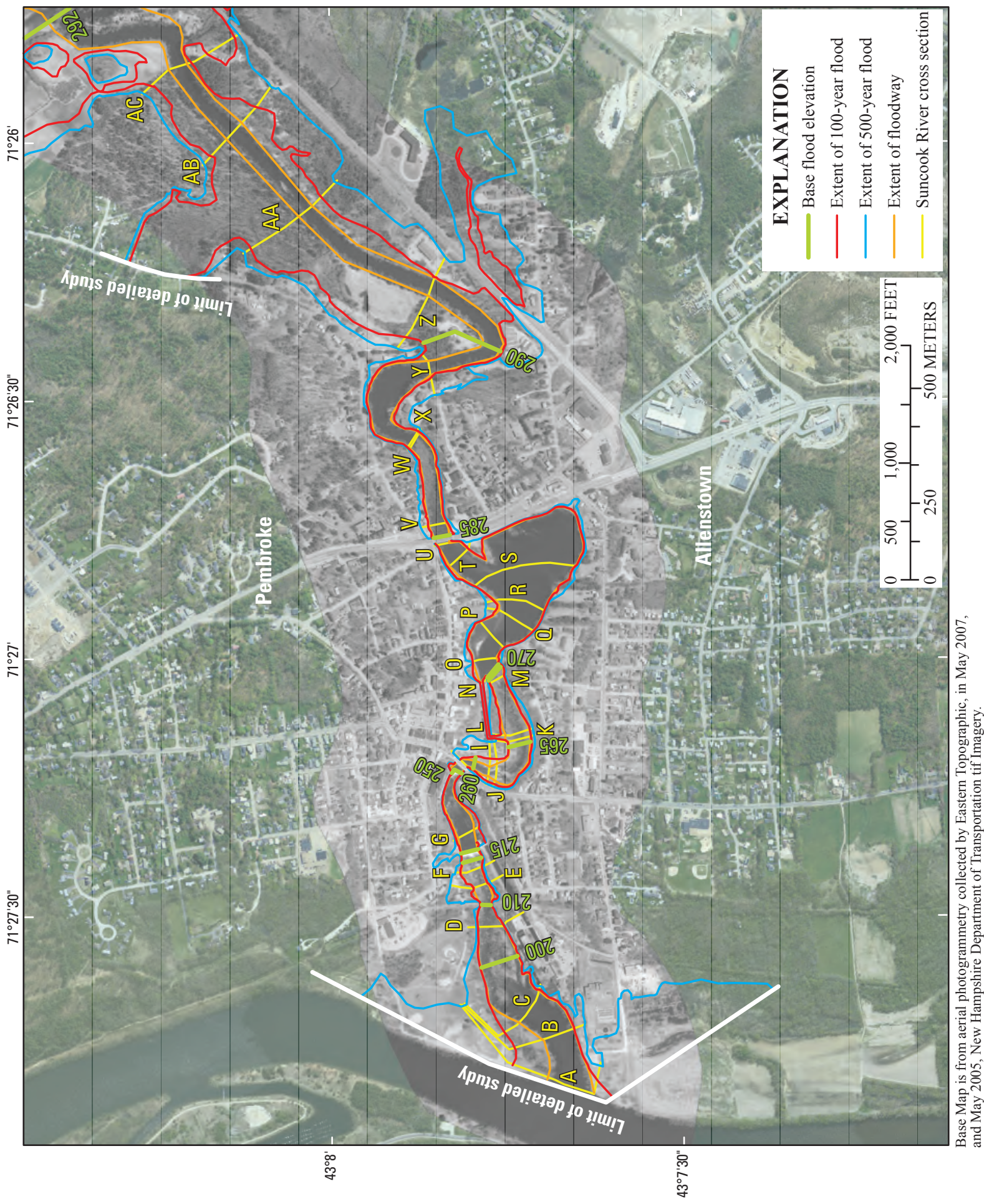

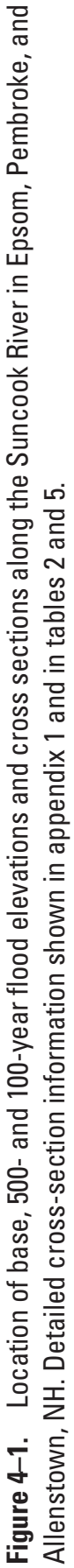




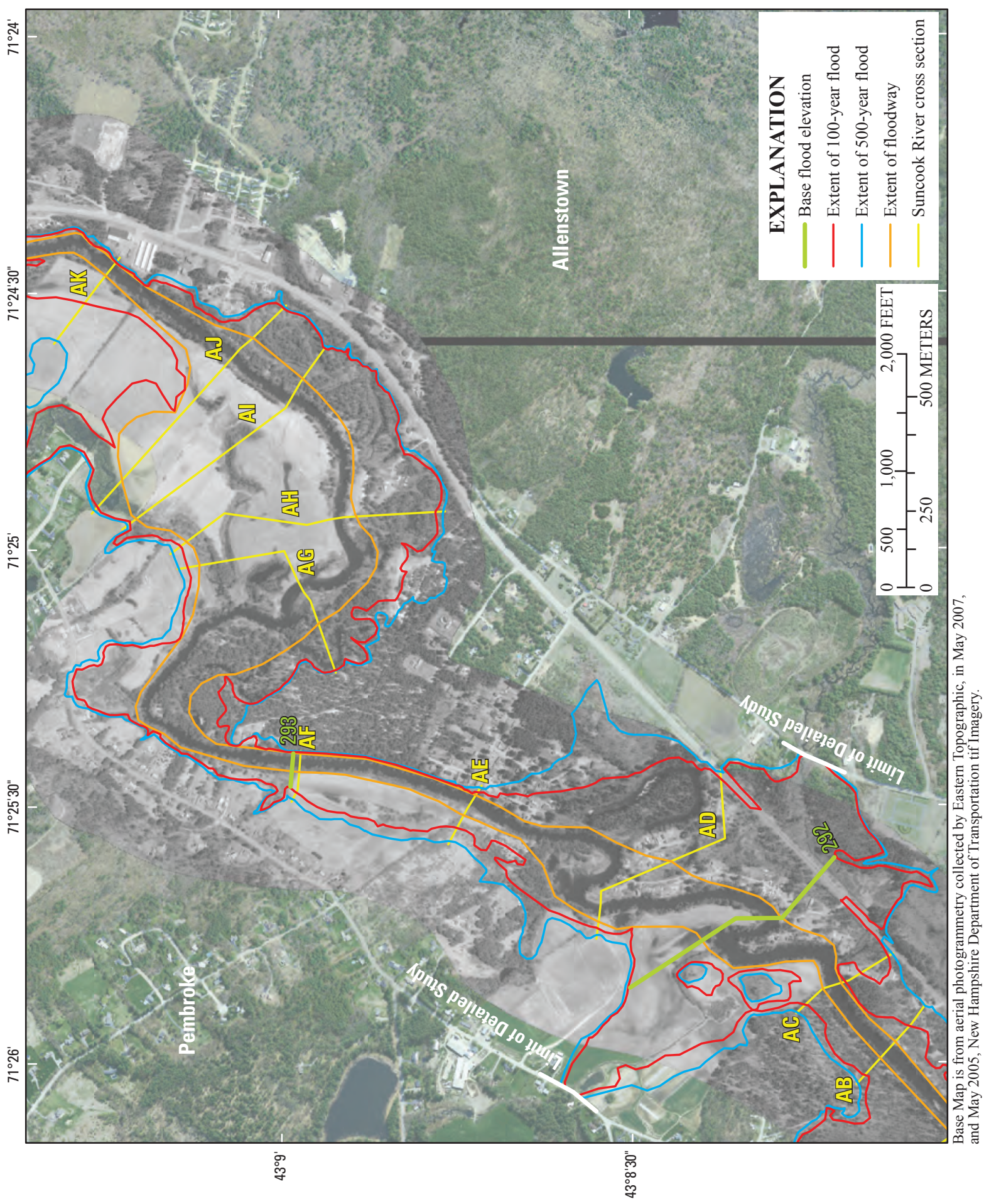

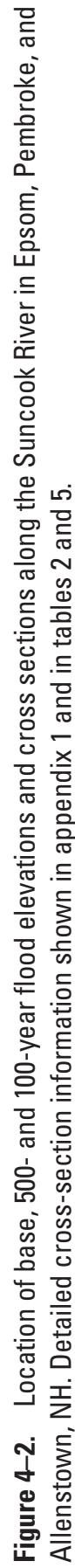




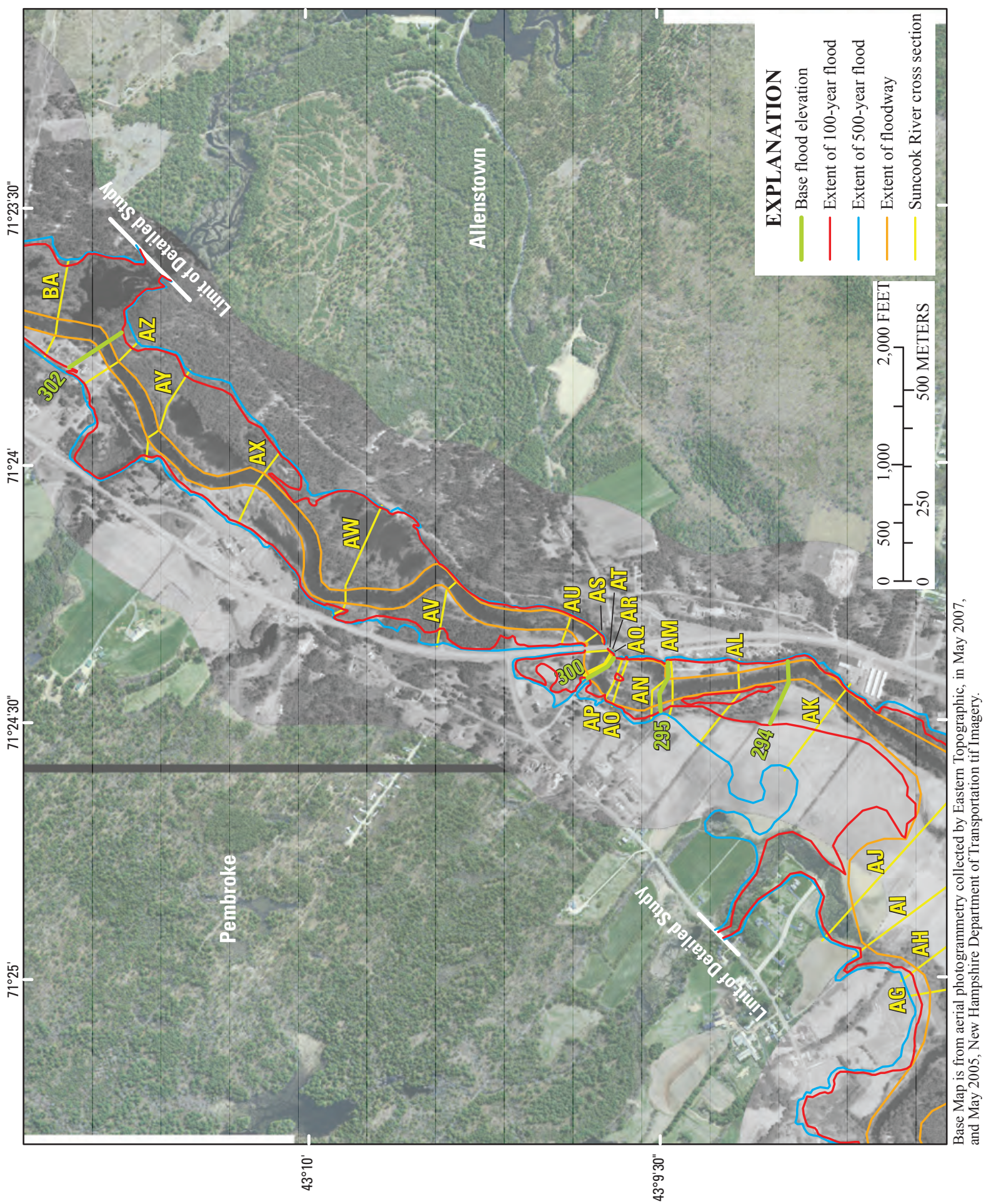

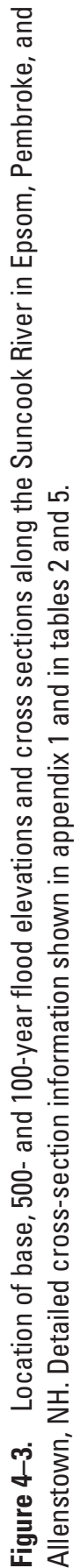




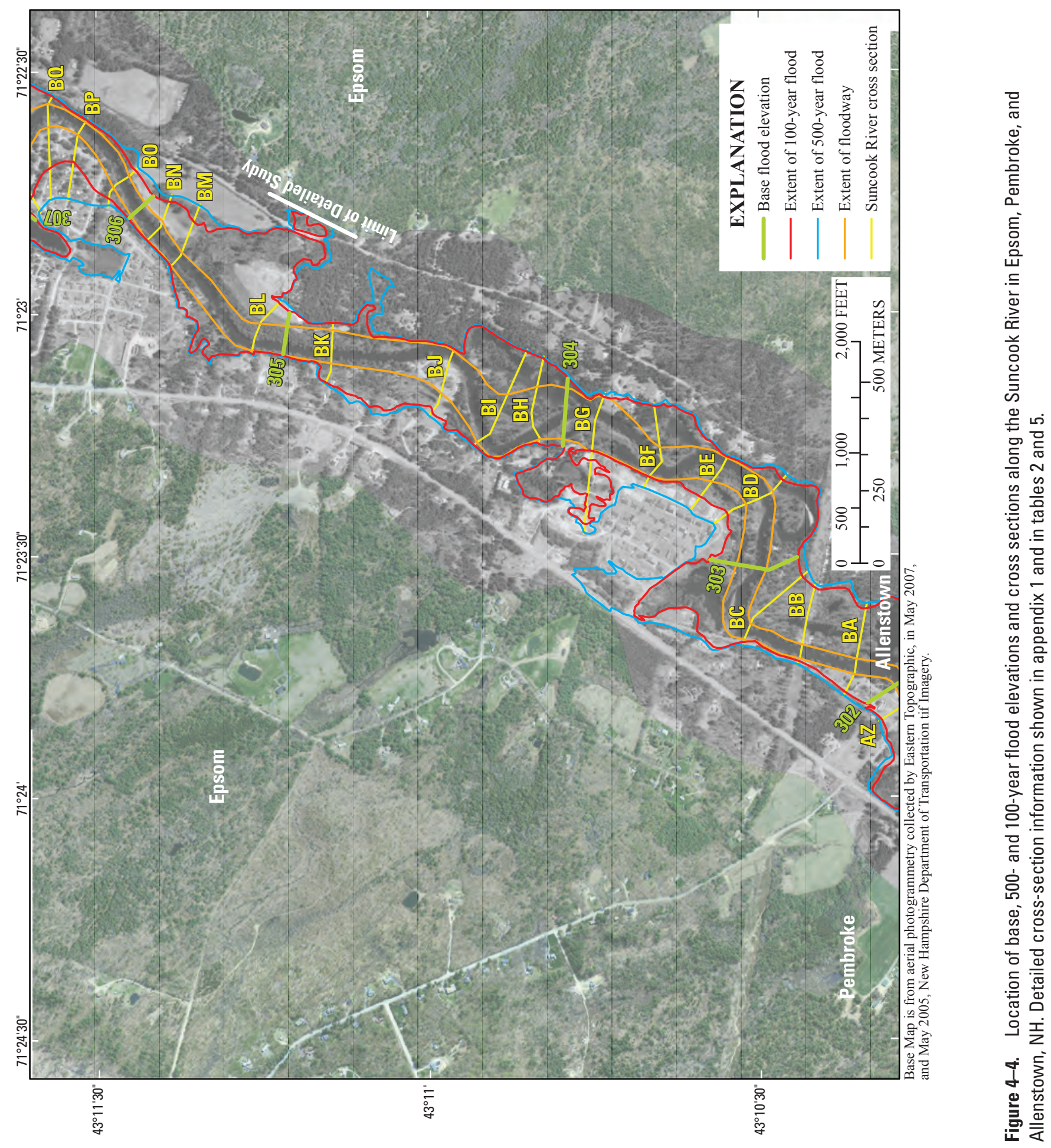




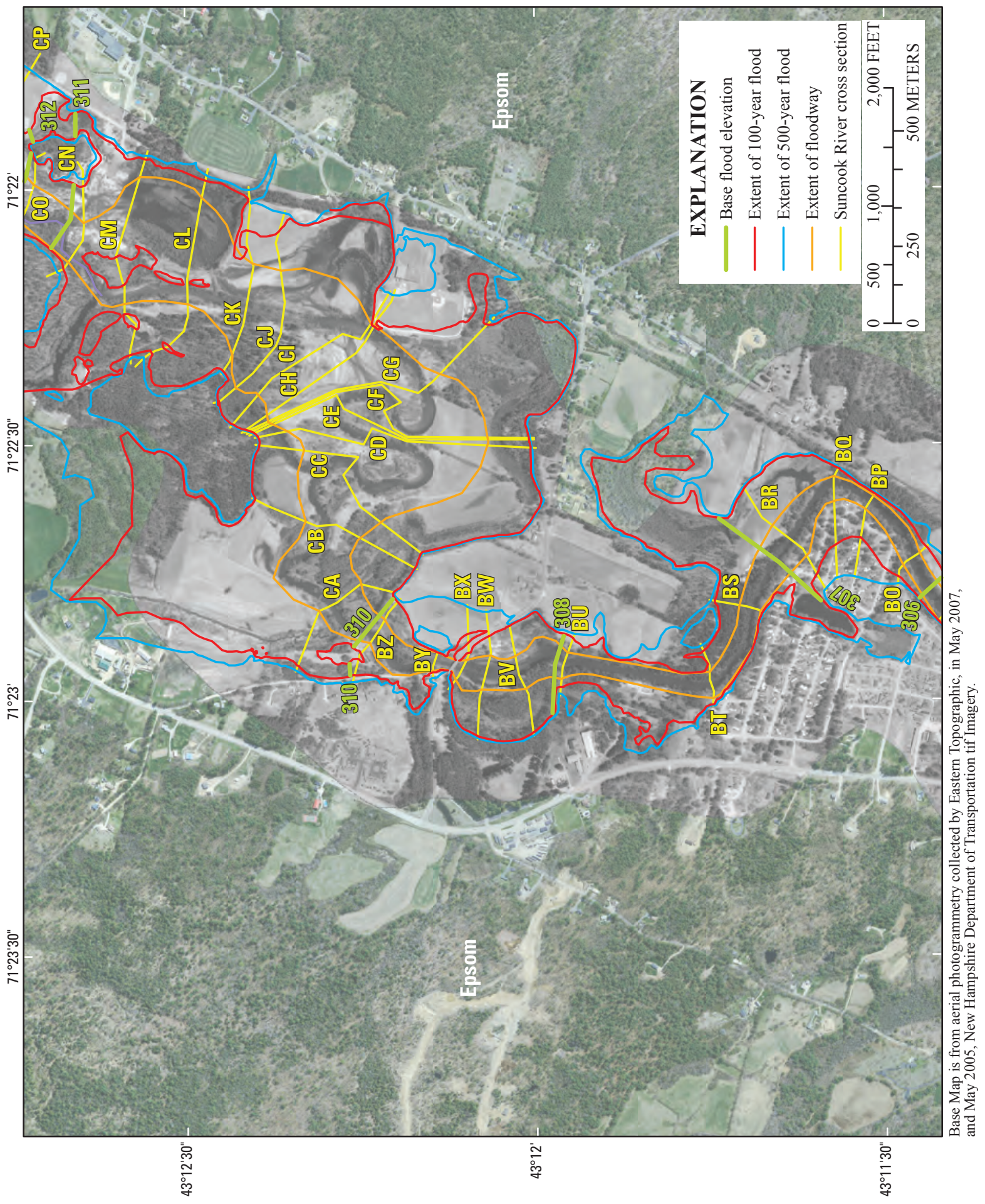

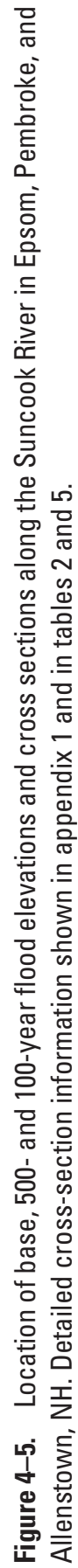




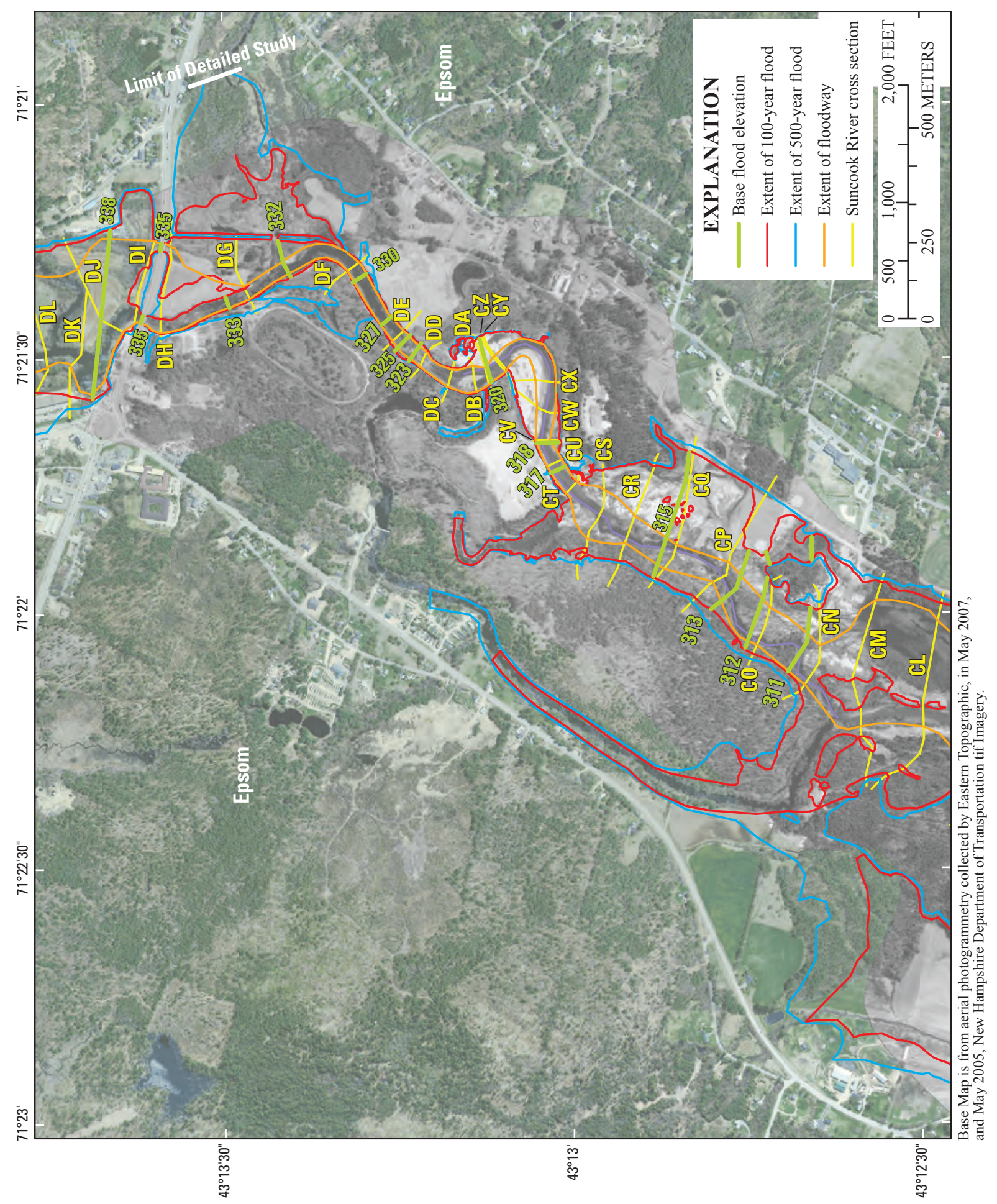

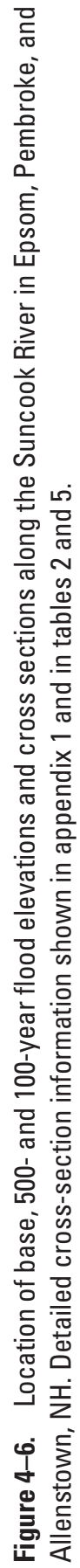




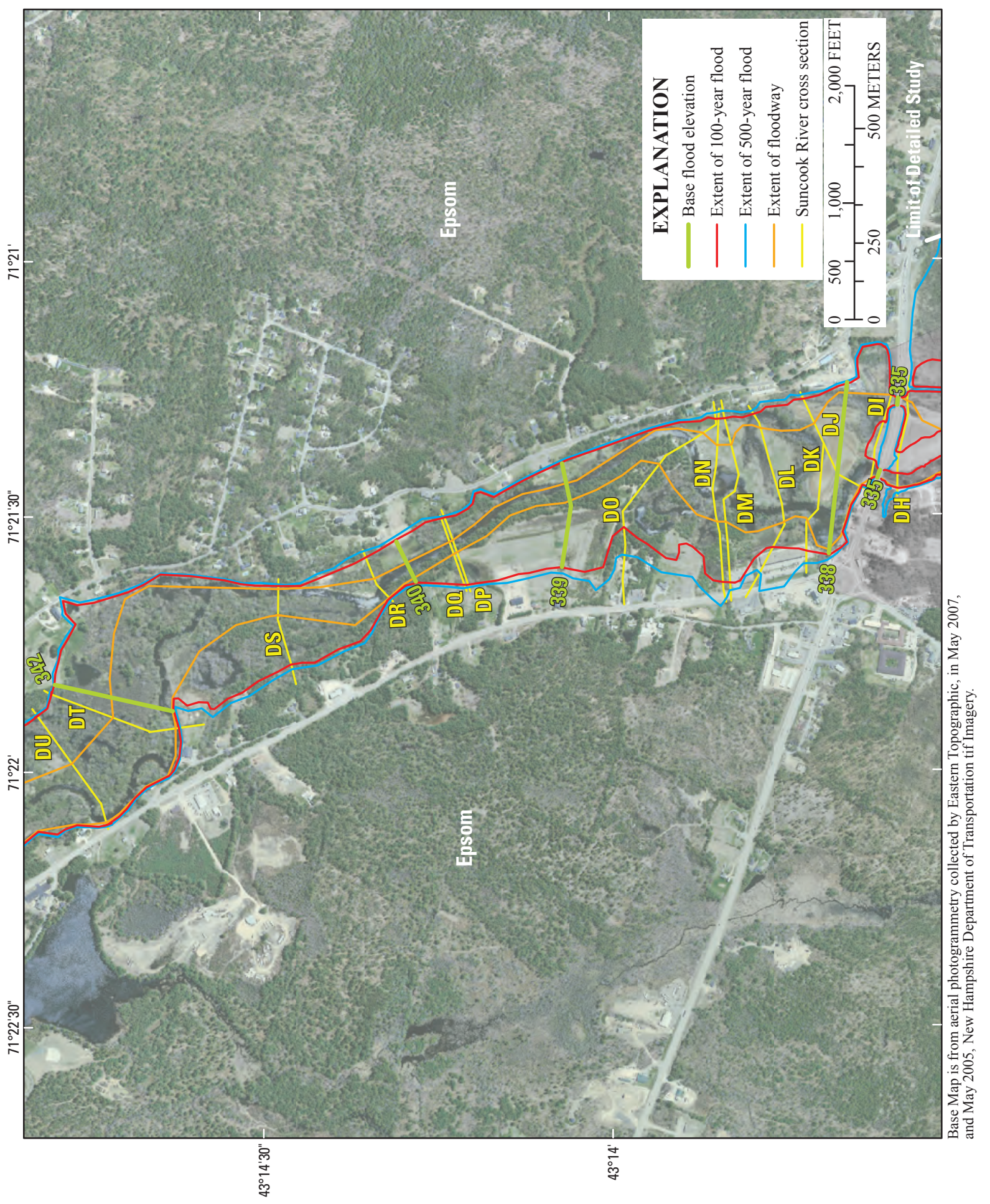

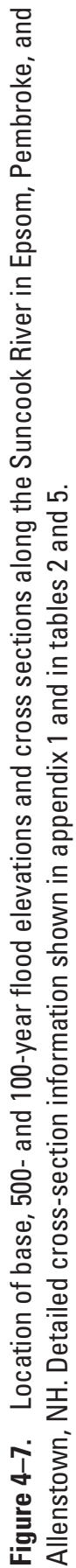




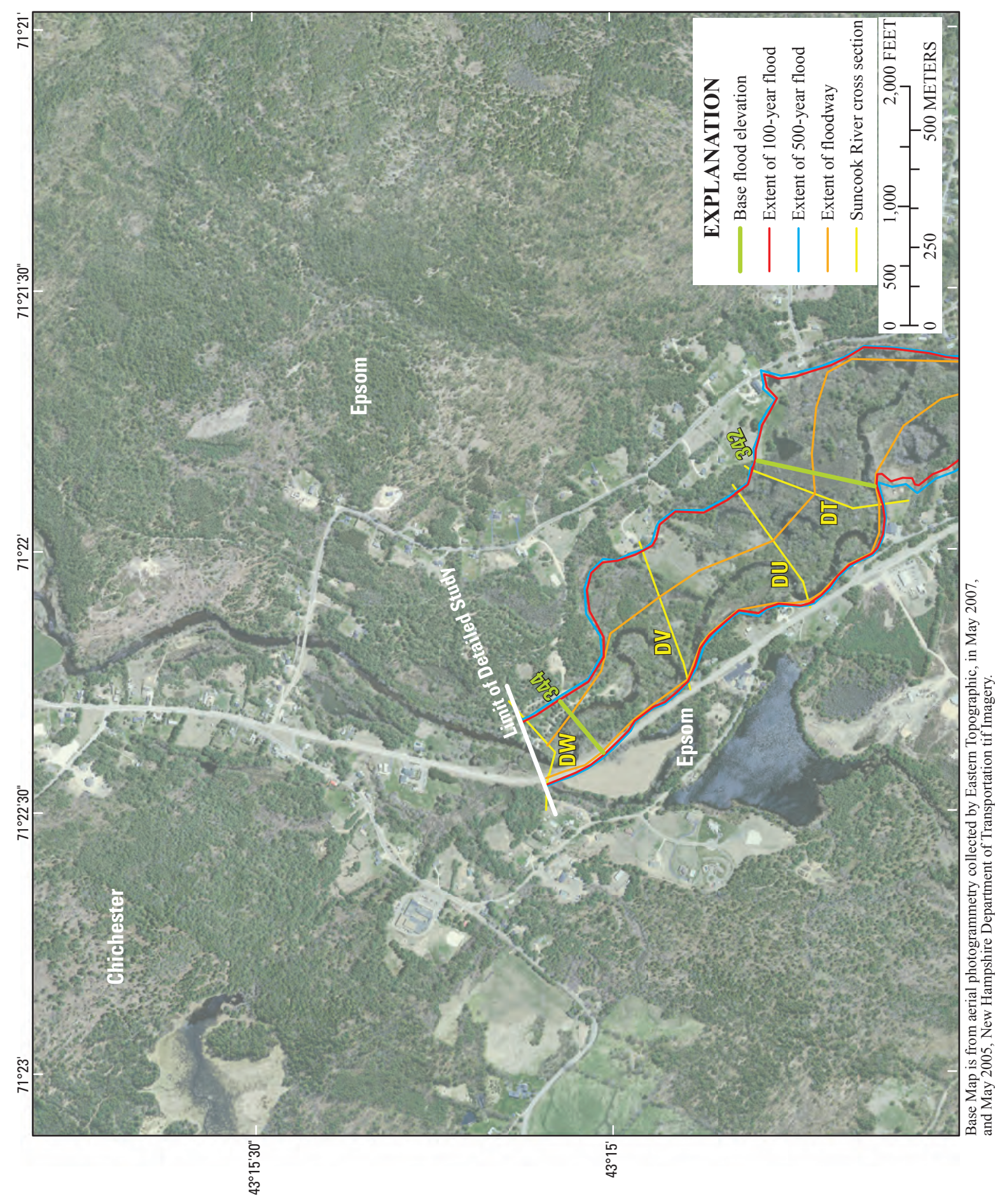

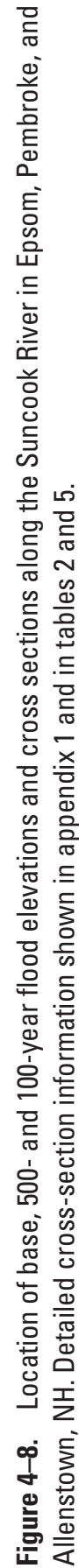


Prepared by the Pembroke Publishing Service Center.

For more information concerning this report, contact:

Director

U.S. Geological Survey

New Hampshire-Vermont Water Science Center

331 Commerce Way, Suite 2

Pembroke, NH 03275

dc_nh@usgs.gov

or visit our Web site at:

http://nh.water.usgs.gov 
